Andrews University

Digital Commons @ Andrews University

Professional Dissertations DMin

Graduate Research

1981

\title{
A Ministry Of Reconciliation
}

Graeme Stanley Loftus

Andrews University

Follow this and additional works at: https://digitalcommons.andrews.edu/dmin

Part of the Practical Theology Commons

\section{Recommended Citation}

Loftus, Graeme Stanley, "A Ministry Of Reconciliation" (1981). Professional Dissertations DMin. 190.

https://digitalcommons.andrews.edu/dmin/190

This Project Report is brought to you for free and open access by the Graduate Research at Digital Commons @ Andrews University. It has been accepted for inclusion in Professional Dissertations DMin by an authorized administrator of Digital Commons @ Andrews University. For more information, please contact repository@andrews.edu. 


\section{INFORMATION TO USERS}

This was produced from a copy of a document sent to us for microfilming. While the most advanced technological means to photograph and reproduce this document have been used, the quality is heavily dependent upon the quality of the material submitted.

The following explanation of techniques is provided to help you understand markings or notations which may appear on this reproduction.

1. The sign or "target" for pages apparently lacking from the document photographed is "Missing Page(s)". If it was possible to obtain the missing page(s) or section, they are spliced into the film along with adjacent pages. This may have necessitated cutting through an image and duplicating adjacent pages to assure you of complete continuity.

2. When an image on the film is obliterated with a round black mark it is an indication that the film inspector noticed either blurred copy because of movement during exposure, or duplicate copy. Unless we meant to delete copyrighted materials that should not have been filmed, you will find a good image of the page in the adjacent frame. If copyrighted materials were deleted you will find a target note listing the pages in the adjacent frame.

3. When a map, drawing . shart, etc., is part of the material being photographed the photograpner has followed a definite method in "sectioning" the material. It is customary to begin filming at the upper left hand corner of a large sheet and to continue from left to right in equal sections with small overlaps. If necessary, sectioning is continued again-beginning below the first row and continuing on until complete.

4. For any illustrations that cannot be reproduced satisfactorily by xerography, photographic prints can be purchased at additional cost and tipped into your xerographic copy. Requests can be made to our Dissertations Customer Services Department.

5. Some pages in any document may have indistinct print. In all cases we have filmed the best available copy.

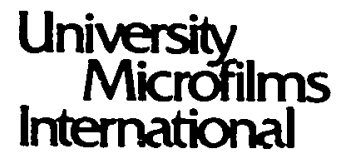

300 N. ZEEB RD., ANN ARBOR, MI 48106 
LOFTUS, GRAEME STANLEY

A MINISTRY OF RECONCILIATION

Andrews University

D.MIN. 1981

\author{
University \\ Microfilms \\ International 300 N. Zeeb Road, Ann Arbor, MI 48106
}

Copyright 1981

by

Loftus, Graeme Stanley

All Rights Reserved 


\section{PLEASE NOTE:}

In all cases this material has been filmed in the best possible way from the available copy.

Problems encountered with this document have been identified here with a check mark

1. Glossy photographs or pages

2. Colored illustrations, paper or print

3. Photographs with dark background

4. Illustrations are poor copy

5. Pages with black marks, not original copy

6. Print shows through as there is text on both sides of page

7. Indistinct, broken or small print on several pages

8. Print exceeds margin requirements

9. Tightly bound copy with print lost in spine

10. Computer printout pages with indistinct print

11. Page(s) author. lacking when material received, and not available from school or

12. Page(s) seem to be missing in numbering only as text follows.

13. Two pages numbered - Text follows.

14. Curling and wrinkled pages

15. Other

\section{University Microfilms International}


Reproduced with permission of the copyright owner. Further reproduction prohibited without permission. 
Andrews University

Seventh-day Adventist Theological Seminary

A MINISTRY OF RECONCILIATION

\author{
A Project Dissertation \\ Presented in Partial Fulfillment \\ of the Requirements for the Degree \\ Doctor of Ministry
}

by

Graeme Stanley Loftus

May 1981 
A MINISTRY OF RECONCILIATION

\author{
A project dissertation presented \\ in partial fulfillment of the requirement \\ for the degree \\ Doctor of Ministry
}

by

Graeme Stanley Loftus

\title{
APPROVAL BY THE COMMITTEE
}
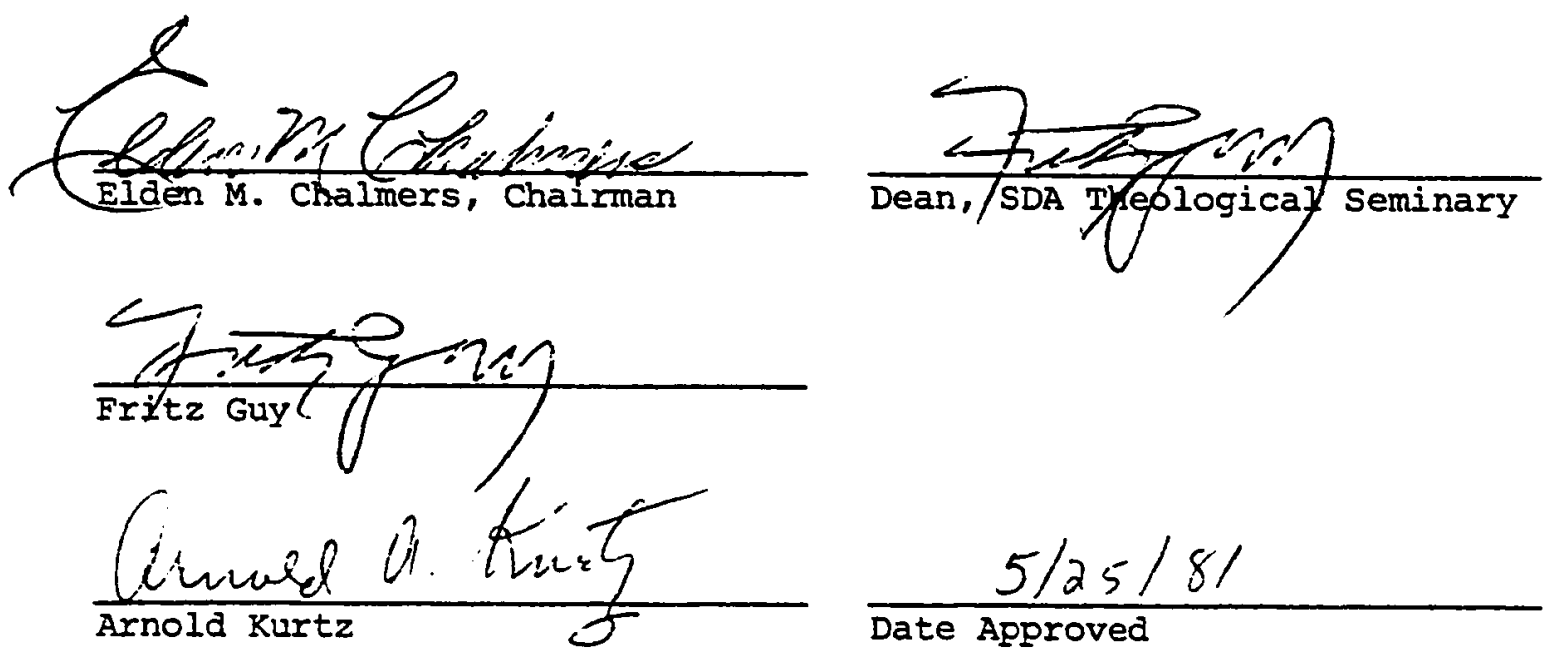

$\frac{5 / 25 / 81}{\text { Date Approved }}$




\section{ABSTRACT}

\section{A MINISTRY OF RECONCILIATION}

by

Graeme Stanley Loftus

Chairman: Elden M. Chalmers 


\author{
ABSTRACT OF GRADUATE STUDENT RESEARCH \\ Project Dissertation \\ Andrews University \\ Seventh-day Adventist Theological Seminary
}

\begin{abstract}
Title: A MINISTRY OF RECONCILIATION
Name of researcher: Graeme Stanley Loftus

Name and degree of faculty adviser: Elden M. Chalmers, Ph.D.

Date completed: May 1981
\end{abstract}

There has been a growing need in the Seventh-day Adventist Church to ground pastoral ministry on an undergirding theology that provides an integrating matrix for all of its tasks. Too often there has been a dichotomy between "pure theology" and "applied theology". Pragmatic and immediate concerns, rather than theology, have usually guided and determined the implementation of most tasks of ministry.

The thesis of this study is that the work of God Himself in ministering to human needs forms a fundamental paradigm for men to construct such an undergirding theology of ministry to their fellows. This concept is pursued specifically in the area of 
reconciliation. God's act of reconciliation through the life, death, and resurrection of Jesus Christ is studied and its implications in the three areas of individual experience, the life of the church in community, and its outreach in mission.

The Glen Ellyn Seventh-day Adventist Church in Illinois was chosen to implement a project along these lines. The theology of reconciliation was spelled out in a series of Sabbath morning sermons and afternoon seminars that provided the main educational thrust. The Sixteen Personality Factor and Motivation Analysis Tests were used in the normal course and crises of parish life to aid in applying this theology to inner alienations. The seminars and mid-week meetings were used to facilitate an experience of reconciled community life. The fostering of personal spiritual gifts together with public evangelism was used to call others to reconciliation.

Evaluations of the project by the church members revealed that over half grasped the theology of reconciliation and were able to successfully apply it to the first two areas. Mission appeared to be the one area where measurable results were not immediately apparent. The pastor found it to be an excellent model to integrate his ministry to the church. 
TABLE OF CONTENTS

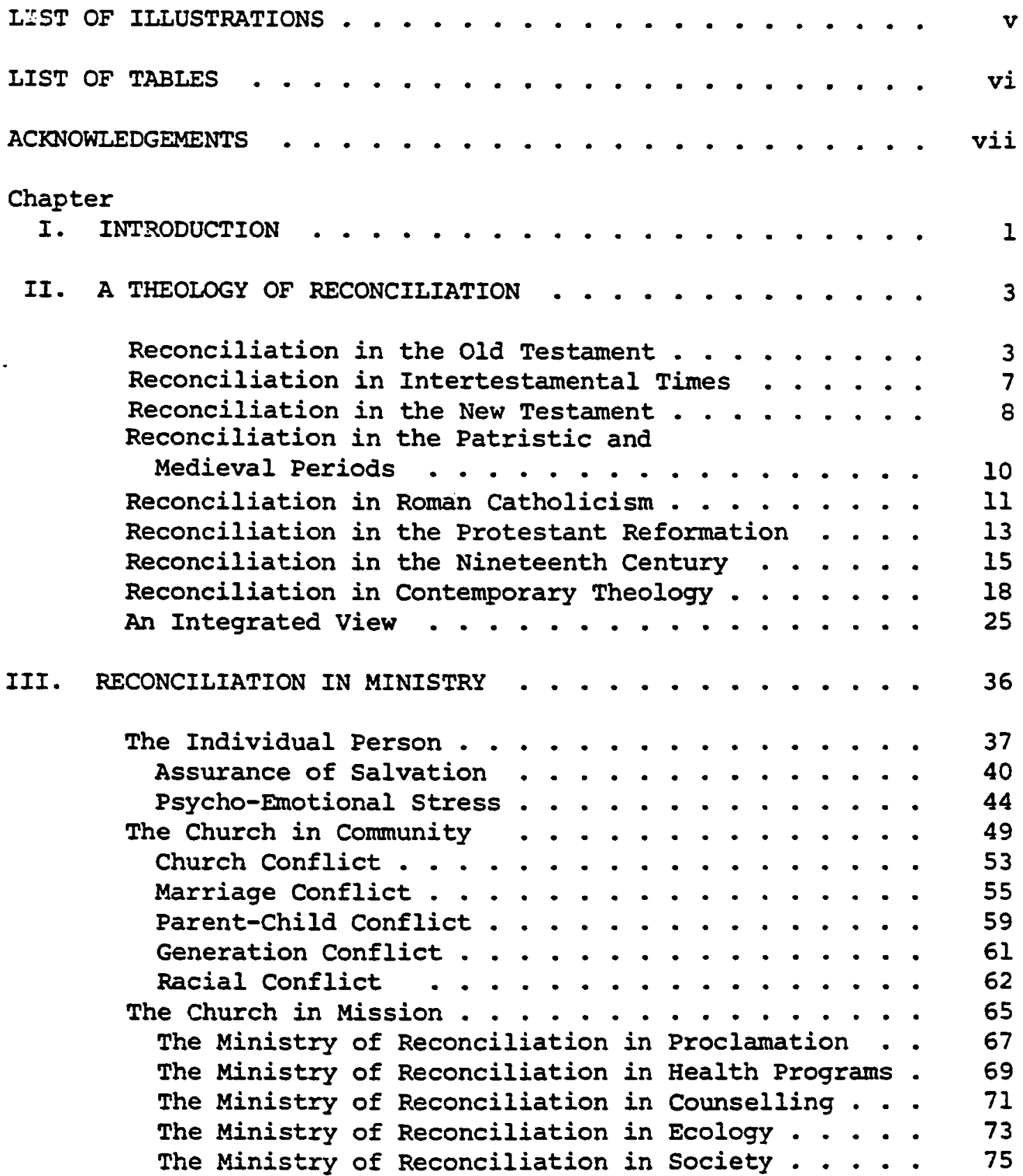


IV. IN PRACTICE . . . . . . . . . . . . . . . . . . . . 78

The Experience of Individuals . . . . . . . . . . 79

The Experience of the Church in Community . . . . . . 82

The Experience of the Church in Mission . . . . . . . 94

Evaluation . . . . . . . . . . . . . . . . 97

By the Church . . . . . . . . . . . . . . 97

By the Author . . . . . . . . . . . . . 116

v. CONCLUSION . . . . . . . . . . . . . . . . . . . . . . . . 122

APPENDICES . . . . . . . . . . . . . . . . . . . . . . . . . 125

SELECTED BIBLIOGRAPHY . . . . . . . . . . . . . . . . . . 184 
1. Underlying Theology of Project ........... 127

2. Chart of Growth over 17 Years . . . . . . . . 167

3. Yearly Rates of Growth ............... 168

4. Chart of Gains and Losses . . . . . . . . . . . 169 


\section{LIST OF TABLES}

1. Vital Statistics for Places in Northeastern Illinois with Population of 10,000 and Over, 1960-1970 . . . . 170

2. General Manufacturing Employment and Production Statistics for Municipalities Having 450 or More Employees, 1967 \& 1963 . . . . . . . . . . 170

3. Selected Characteristics of Children under 18 years of Age--1970 . . . . . . . . . . . . . . . 171

4. Characteristics of the Aged--1970 . . . . . . . . . . 171

5. Occupational Characteristics--1970 . . . . . . . . . 172

6. Commuting Characteristics--1970 . . . . . . . . . . . 172

7. Income Characteristics--1970 . . . . . . . . . . . 173

8. Labor Force Characteristics--1970 . . . . . . . . . 173

9. Population Changes--1950-1970 . . . . . . . . . . . . 174

10. Percentage of Population by Age and Sex--1970 . . . . . . 174

11. Racial Distribution--1970 . . . . . . . . . . . 175

12. Educational Characteristics of Residents of Places with Populations of 2,500 or More . . . . . . . . . 175 


\section{ACKNOWLEDGEMENTS}

Any study such as this could not have been possible had many people not provided support and help during its course.

The Australasian Division of Seventh-day Adventists graciously provided leave of absence and partial sponsorship to complete this degree.

The Illinois Conference of Seventh-day Adventists cooperated by providing employment for two years to enable the practical aspects of the project to be carried out in field experience. The Glen Ellyn Church willingly agreed to be the subject of experimentation in the project and constantly maintained an openress and support towards the concepts presented.

My wife Avalon spent many hours typing this and other manuscripts. She, together with our two sons Jeremy and Benjamin, have joined with me in this odyssey to find effectiveness in ministry. It is their project as well as mine. 
DEDICATED TO

\author{
those churches in Western Australia whose hunger \\ for assurance of salvation molded my early \\ ministry and showed me the need for \\ undertaking such a study
}

Reproduced with permission of the copyright owner. Further reproduction prohibited without permission. 
CHAPTER I

INTRODUCTION

It would seem to be beneficial for churches and their pastors to ask: "What is the nature of the ministry which occupies us?" To ask the question necessarily drives us back to the foundational work of God Himself in meeting the needs of men. Is there not a fundamental paradigm of ministry demonstrated in God's ministry for us and our salvation?

In this study an attempt is made to present an alternative to the customary dichotomy between "pure theology" and "applied theology", and to avoid the way in which pragmatic and immediate concerns usually guide and determine the tasks of ministry. Theology must be seen as working itself out in the life and ministry of the church in terms of the gospel of Jesus Christ. The biblical picture of reconciliation provides a strong theology that can express the gospel in terms of practical ministry. Today the Seventh-day Adventist Church at large is engaged in an increasing amount of introspective analysis and doctrinal discussion. These currents of thought and debate are certain to affect the practical life and outreach of the local church. A serious attempt on the part of the pastor to think through a basic undergirding theology of ministry would seem to be essential, and 
2

this study is a step in that direction. It represents the distillation of all of the author's struggles to find an integrated approach to meaningful ministry. 


\section{A THEOLOGY OF RECONCILIATION}

\section{Reconciliation in the old Testanent}

There is a very close connection between the words "reconciliation" and "atonement" when their translation in the old and New Testaments is examined. In the King James Version of the Bible the word "reconciliation" occurs eight times in the old Testament and twelve times in the New Testament. In the Revised Standard Version the same word is translated in the old Testament seven times "to atone" and once "to reconcile" (and that in a person to person context in 1 Sam 29:4); while in the New Testament it is translated "to reconcile" eleven times and "to expiate" once. Strangely, the word "to atone" occurs only once in the King James Version of the New Testament (Rom 5:11), but in the Revised Standard Version it is rendered "to reconcile".

Obviously then, "reconciliation" and "atonement" are very close in their meaning, but "reconciliation" has no exact equivalent in the old Testament and the words are not exactly synonymous. Vorlander ${ }^{l}$ points this out when he notes that in translating the language of atonement taken from the technical priestly vocabulary,

${ }^{1}$ H. Vorlander, "Reconciliation," The New International Dictionary of the New Testament Theology (NIDNTT) (Grand Rapids: Zondervan, 1978, 3:167. 
the Lxx prefers similar cultic terms like purify, atone, expiate, or propitiate, because katallasso and its derivatives are not found at all in cultic and priestly contexts. They both involve a harmonious relationship between previously alienated and estranged parties. In the old Testament this involves more than reconciliation with one's neighbor; it includes reconciliation with God, with one's inner self and with the world of nature and humanity.

Reconciliation with God is necessary because sin, seen in its various phases as breaking covenant obligation, missing the mark, wandering from the right path, turning aside from the right way, or rebellion, the direct disobedience of a personal God, has separated man from God. The exact meaning of atonement is uncertain. The Babylonian root of the word implies "to wash away" but the Arabic root implies "to cover". ${ }^{1}$ one thing is certain grammatically, however, and that is that God is never the object of the verb "to atone". Some modern commentators ${ }^{2}$ make much of this structure and maintain that atonement is not placation of God so much as it is expiation of sin. God is portrayed as providing atonement for man, they say, but does not in Himself need to have His own attitude changed. The fact that propitiation is also included in atonement, however, has been successfully established by men such as D. Hill and L. Morris.

Early evidence of alienation appears in the old Testament

IE. C. Blackman, "Reconciliation," Interpreter's Dictionary of the Bible, 4 vols. (New York: Abingdion Press, 1962), 4:16.

2 For a good summary of these views held by men such as von Rad, Oehler, and Dodd, and their rebuttal by Hill and Morris, see NIDNTT, Pp. 151-154. 
between Adam and Eve, Cain and Abel, the different language of groups at the tower of Babel, and Israel in its conflict with surrounding cultures. After the time of the monarchy, further alienation appears between God and the king, rich and poor, prophet and priest, north and south. ${ }^{1}$

Alienation was overcome in the ritualistic form of the atonement with the shedding of the blood of animal sacrifices (Lev $6: 30$; $8: 15$; $16: 18-22$; 2 Chron 29:24; Ezek 45:20). Many ${ }^{2}$ have considered such sacrifices as crude and primitive, revealing the influence of surrounding cultures on Hebrew faith as Israel sought to propitiate the wrath of a capricious, temperamental, and angry God. The Bible reveals, however, that the Hebrew faith involved a deep moral consciousness intertwined with religious conviction. Without the shedding of blood there was no remission of sin (Heb 9:22). Gideon called his altar "The Lord is Peace" (Judges 6:24). Some $^{3}$ have seen a progress to higher concepts of reconciliation in the Psalms where man's penitence and God's steadfast love are portrayed (Ps $25: 7 ; 51: 1 ; 130: 3 ; 62: 1 ; 85: 8-11$ ). The major prophets supposedly reveal still more mature development as the ritualistic sacrifices are repudiated in the absence of ethical responsibility. Four concerns appear paramount in passages like Amos 5:21-22; Hos $6: 6$; Isa $1: 14-20$; Mic $6: 68$ :

${ }^{1}$ S. T. Kimbrough, Jr., "Reconciliation in the old Testament" Religion in Life 41 (Spring 1972): 37-45.

2 NIDNTT, $3: 150$.

${ }^{3}$ G. Harkness, The Ministry of Reconciliation (Nashville, N.Y.: Abingdon, 1971), P. 24. 
(a) supreme allegiance to Yahweh

(b) economic justice for all

(c) righteousness placed above ritualistic correctness

(d) inevitable doom which a loving God must send on the impenitent

The highest form of reconciliation appears in the new covenant (Jer $31: 31-34$; Isa $40 ; 54: 4-5)$ and is further embellished in the priestly code where man is pictured in ideal relationship with God.

There is a certain element of truth in this thesis of an emerging concept of reconciliation if it is considered from the point of view of man's awareness of what God envisaged originally. It would be false, however, to suppose that this in any way superseded the sacrificial aspects of atonement. The highest form of all, the "priestly code", can be shown to be Mosaic in origin and inherent in God's plan for reconciliation from its inception. God is revealed in the old Testament as the "merciful" and gracious one, who reveals "steadfast love" and who promises forgiveness and restoration of the covenant as His sovereign work.

Reconciliation between men is seen in the experience of Esau and Jacob (Gen 34) and David and Saul (1 Sam 24). The moral codes for group relations reveal social justice which is a form of reconciliation. The wisdom literature is full of statements concerning harmonious human relations (Prov 15:1; 17:14; $2: 10 ; 21: 19$; 25:21-22). The greeting "shalom" (peace be with you) evidences widespread use in the old Testament (Judges $6: 23 ; 19: 20 ; 1$ Sam 25:6; 1 Chron 12:18; Ps 122:8; Dan 4:1). And finally, the eschatological aspects of reconciliation are considered in Isa 2:2-4; Mic 4:1-3. 
Morrison ${ }^{1}$ summarizes this when he points out that the story of the whole Bible is one of "God reconciling". If the appearance of Jesus marks a new covenant, it nevertheless shares in the same purposes of the old.

\section{Reconciliation in Intertestamental Times}

The words $k x T \alpha \lambda \lambda \alpha T T G y$ and $K \alpha T \alpha \lambda \lambda \alpha T T E J O \alpha 1$ play no essential part in even the expiatory rites of Greek and Hellenistic pagan religion though they are used in a religious sense. The relation between divinity and humanity in these heathen religions does not have the personal sense of nearness implied in these words.

In Greek-speaking Judaism, if as a result of the prayers or confessions or conversion of men God renounces His wrath and is

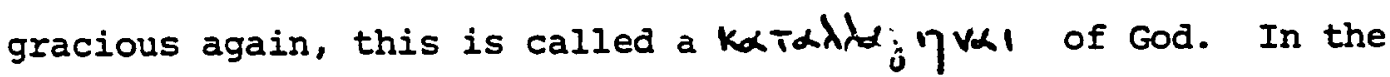

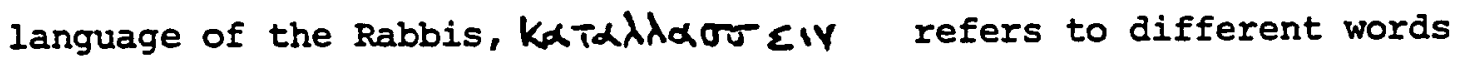
which have the meaning of "to make benevolent or well disposed," "to placate," "to reconcile oneself," "to be reconciled or appeased," "to be kindly disposed". These words refer to the relations between men, and between God and men. God is the subject to the reconciling action of men in prayer, sacrifice, etc. ${ }^{2}$ The old Testament proclamation of the grace of God is foreshortened in passages like 2 Macc 1:5; 7:33; 8:29; sir 16:12. ${ }^{3}$ Developing legalism is seen when the fulfillment of the law becomes a means to the end of achieving

Ic. Morrison, "God's Reconciling Word," McCormick Quarterly 19 (January 1966):87.

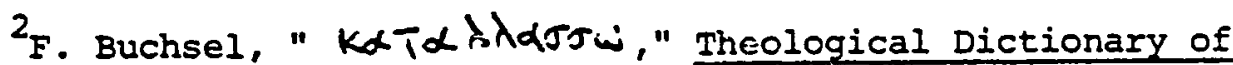
the New Testament (TDNT) (Grand Rapids: Eerdmans, 1964), 1:254.

3 NIDNTT, $3: 167$. 
righteousness before God with the consequence that the thought of reconciliation can find itself in close proximity to that of reward.

Leon Morris has summarized rabbinical understandings of reconciliation well when he says:

Thus the Jews certainly held that God was angry when men sinned, and that this demanded an act of reconciliation. They do not hesitate to speak of God as being reconciled to man, by which they mean that His just wrath is removed. There is divergence of opinion about the method of effecting reconciliation, but the best Rabbinic thought had risen to the idea that God himself brings about the reconciliation. On the human side the Rabbis lookepd for repentance and a readiness to be reconciled to other men.

Reconciliation in the New Testament

$\delta \alpha \lambda \lambda \alpha \sigma \sigma \omega{ }^{2}$ occurs once in the New Testament (Matt 5:24)

and involves an angry brother, who neither seeks nor envisages reconciliation, actually being led to renounce his enmity. $\delta 1 \alpha \lambda \lambda \alpha \sigma \sigma \omega$ is thus a two-sided process in which the hostility is overcome on both sides.

$K \propto T \propto \lambda \lambda \propto \sigma \sigma \omega^{3}$ involves the thought of change. In 1 cor 7:11 the usage is similar to that of $\delta \alpha \lambda \lambda \alpha \sigma o w$ in Matt 5:24. In this case the word implies an action on the part of the wife separated from her husband, and not merely something which happens to her.

In all other usages of the word the relationship between God and man is involved, and Paul is the only author to use it.

\footnotetext{
I Leon Morris, The Apostolic Preaching of the Cross (Grand

2TDNT, s.v. "Sk $6 \lambda \lambda \alpha \sigma \sigma \omega, " 1: 253$.

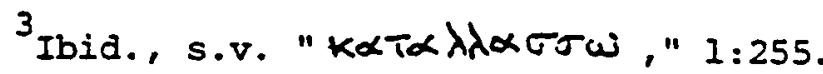
Rapids: Eerdmans, 1965), p. 219. 
$k \alpha T \alpha \lambda \lambda_{\alpha} \sigma \varepsilon l y$ is used only of God, $k \alpha T \alpha \lambda \lambda \alpha \gamma \eta v \alpha l$ only of man. God reconciles us or the world to Himself in 2 Cor 5:18-21. He is not reconciled. Nor does He reconcile Himself to us or to the world. on the other hand we are reconciled to God (Rom 5:10), or reconcile ourselves to Him $(2 \operatorname{Cor} 5: 20)$. Thus God and man are not on equal terms in relation to reconciliation. Reconciliation is not reciprocal in the sense that both equally become friends where they were enemies. The supremacy of God over man is maintained in every respect. Reconciliation is accomplished by the death of Christ. This is pointed out by both Fitzmyer ${ }^{1}$ and Berkouwer ${ }^{2}$ who note that the main effect of Christ's passion, death, and resurrection is "the restoration of man to a state of peace and union with the Father." Katallage has as its essence the concepts of access, boldness, peace, and trust since the removal of all obstacles to access to the Father has been accomplished.

wilder shows that even though the term katallage is a strictly Pauline one used on only a few occasions, it is still possible to go behind the variety of New Testament formulations of the work of Christ and see reconciliation in passages in the Gospels, "such as the Parable of the Prodigal Son, and motifs in the Gospel According to John, which are associated with the peace Christ bestowed on his disciples." ${ }^{3}$

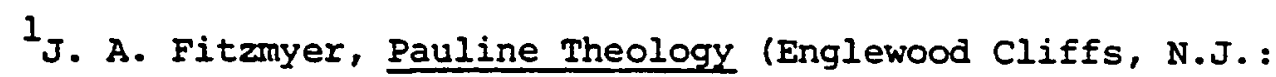
Prentice Hall, 1966), pp. 43, 44.

${ }^{2}$ G. C. Berkouwer, The Work of Christ (Grand Rapids : Eerdmans, 1965), p. 255.

${ }^{3}$ A. N. Wilder, "Reconciliation-New Testament Scholarship and Confessional Differences," Interpretation 19 (1965): 317. 
Reconciliation in the Patristic \& Medieval Periods

The church fathers rarely use the word "reconciliation." I

They thought more in terms of atonement but were even a long way from understanding that in the proper New Testament usage. Their theology revealed an embryonic form of sacramental reconciliation that was to come to full flower in Thomas Aquinas and the Tridentine theology of the Roman Catholic Church, and this can be seen in Justin Martyr, ${ }^{2}$ Tertullian, ${ }^{3}$ Hermas, ${ }^{4}$ and Ignatius. ${ }^{5}$

Thomas Aquinas viewed reconciliation as an appeasement of an angry God and did not seem to grasp the work on the cross as a representative expiation of mankind's guilt. The moral worth of Christ's death is the feature that seems to "appease" God" ${ }^{6}$, but in what sense the act was good is not made clear. In article 1 of question 49 in his Summa, Aquinas spells out his understanding of how Christ's passion is efficacious. The cross excites our charity, which procures pardon for our sins, and operates with divine power to expel sin. Thus the cultic activity of the mass was a ministry

${ }^{1}$ See G. W. H. Lampe, A Patristic Greek Lexicon (Oxford:

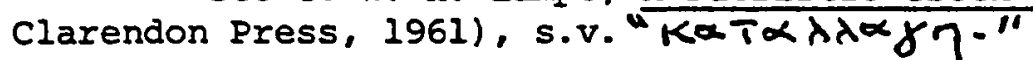

2 Justin Martyr Dialogue with Trypho 13. (Unless otherwise indicated, all references to church fathers are taken from AnteNicene Fathers.)

3 Tertullian Baptism $3: 669$.

4 Hermas Pastor Similitude 5.6.2:35.

5 Ignatius Epistle to the Smyrnaens 7.1:89.

6 Thomas Aquinas, Summa Theologica, 3 vols (New York: Benziger Brothers Inc., 1947), III.49.4. 
designed to bring about reconciliation or to reenact it. Vorlander ${ }^{1}$ points out from a consideration of the "message of reconciliation" and the "ministry of reconciliation" in 2 Cor 5:18, 20, that this patristic understanding is not biblically valid. Kasemann also argues persuavisely that

- . the basic meaning and actuality of reconciliation cannot be identified with official formulations or particular cultic channels defined by the church as normative. Sacrificial and expiatory aspects of such formulations, for example, rest on secondary elements in scripture. Even in the epistle to the Hebrews the cultic dimension is expressly superseded. "The New Testament is a breaking through of the whole cultic category." 2

\section{Reconciliation in Roman Catholicism}

Modern Catholicism has not modified the essence of Aquinas' position on reconciliation even though Catholic scholars have refined their Biblical study of the concept. Reconciliation is considered as a process rather than an act, and something done by the estranged parties rather than something that happens to them. This "process" is identified with that of redemption and issues ultimately into a "state" of reconciliation "by the fact that man is interiorly transformed and justified the root of enmity between God and man has ceased to be". 3 That this is just a modern restatement of a basic Thomistic position can be seen when comparison is made with the following words of Aquinas:

\footnotetext{
$1_{\text {NIDNTT }}, 3: 171$.

2 wilder, p. 212 .

3 New Catholic Encyclopedia, 12 vols. (New York: McGraw Hill, 1967) S.v. "Reconciliation with God."
} 
The change involved in reconciliation occurs on man's side, not on God's. Through a God-given change, man ceases to be the fit object of divine wrath and is embraced once more by God's eternal and effective love.

This highlights the classic Roman Catholic position that God accepts a person on the basis of his subjective inward renewal rather than the objective representative work of atonement worked out historically in the doing and dying of Christ.

The modern Catholic scholar Christian Duquoc recognized the tension between the sacramental understanding of reconciliation as a process and the Protestant view of a finished work and expressed the intrinsic problem facing every Catholic's experience of reconciliation when he pointed out that the two sacraments of eucharist and penance are superfluous if reconciliation is already achieved. ${ }^{2}$ The consequence of this Roman Catholic understanding of reconciliation is that the communicant never in this life experiences assurance of his at-one-ment with God. It is a work that is always progressing, always in the future in its completeness. Grace from the Eucharist purportedly cleanses and renews the Catholic with a power that "projects him towards a culmination which is nothing less than total reconciliation with God and with men, to be sought again and again because never encountered in its fulness". 3 Nowhere is this Catholic understanding of reconciliation more thoroughly

$1_{\text {Thomas Aquinas, Suma Theologica, }} 2: 2290$.

${ }^{2}$ C. Duquoc, "Real Reconciliation and Sacramental Reconciliation" in Sacramental Reconciliation, ed. E. Schillebeeckx (New York: Harder and Harder, 1971), p. 27.

3 Ibid., p. 45. 
demolished than in Barth, who after consideration of the church's teaching, concludes:

It would have to notice that the subjective side to which it has everywhere addressed itself in the sphere of those two-fold concepts is utterly dependent upon and can be known and determined only by the objective, which it has commemorated but then abandoned it as though it were only a conditio sine qua non. It would have to learn to trust that the genuinely subjective is already included in the true objective, and will be found in it and not elsewhere.

\section{Reconciliation in the Protestant Reformation}

Reconciliation does not figure prominently as a central

theme in the writings of the Reformers. Martin Luther did not leave a record of any sermon on the key passages in Romans 5 and 2 Corinthians 5. He does not seem to have even used the term at all. There can be little doubt that the two dominating conceptions of medieval piety and theology; grace and merit, and adjustment between them crowded out the idea of reconciliation. The strongly personalistic quality of the reconciliation theme was not considered important at this time because the forensic concepts of justification dominated reformation thinking. But as the Roman Catholic scholar Harry McSorley ${ }^{2}$ recognizes, Luther nevertheless had a very personal subjective emphasis in his understanding of the sacrament of penance, believing that it was necessary to grasp firmly by faith that his sins were forgiven when he heard the words of absolution.

${ }^{1}$ Karl Barth, Church Dogmatics, 4 vols. (New York: Charles Scribner's Sons, 1956), 4/1:87.

2 Harry McSorley, "Iuther and Trent on the Faith Needed in the Sacrifice of Penance," in Sacramental Reconciliation, p. 98. 
This position was taken by several distinguished bishops and theologians of Trent without their being censured. The reality of a deeply personal experience of being restored by grace to fellowship with God was there in Protestantism. The difference was that it was interpreted in terms of justification rather than the sacraments. Reconciliation was occasionally used as a synonym for justification. John Calvin has much more to say about reconciliation, but it is still not central. He only treats it in the due course of his commentaries and sees it as a synonym for the gospel, justification by faith and forgiveness. Calvin used the term in a polemical attack against the Tridentine understanding of the term when he wrote: "The ministry of reconciliation is not a magical application such as the papists contrive, but the preaching of the gospel." 1 He did not deny that the grace of God was applied to Christians in the sacraments and that their reconciliation with God was confirmed in their consciences, but he would not accept the sacrament as either the act or process of reconciliation. He very much set the stage for later Protestant thought regarding reconciliation as an objective work done for sinful man by God through the atonement.

Our reconciliation with God depends only on Christ, for he only is the beloved son, and we are all by nature the children of wrath. But this favour is communicated to us by the gospel; for the gospel is the ministry of reconciliation by the means of which we are in a manner brought into the kingdom of God.

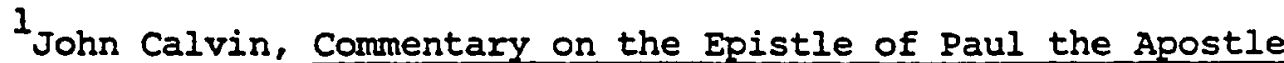
to the Corinthians, 2 vols. (Grand Rapids: Eerdmans, 1948), 2:229242 .

2 John Calvin, Commentaries on the Epistle of Paul the Apostle to the Romans (Grand Rapids: Eerdmans, 1947), pp. 187-199. 
Calvin had a strong view of the sovereignty of God and a radical view of sin. He had a problem with Paul's logic and could not accept that we were loved in any way for our intrinsic worth. It was only in Christ that God could love us, and only after Christ had propitiated His fierce wrath against us. Even though Calvin granted that the love of God was first in point of time and order, he could only conceive of God as angry with man without a mediator interposed to pacify Him. ${ }^{I}$

This concept of the need to propitiate God's fierce wrath often appears in both Calvin ${ }^{2}$ and the other reformation writers and has caused many contemporary writers to falsely label this as a crude "Umstimmung Gottes". Berkouwer ${ }^{3}$ shows convincingly that these charges from men such as Ritschl and Korff do not do justice to the reformers. He examines the Belgic Confession Article 2l, The Canons of Dort 11: 1, 2, 3; V:7; The Westminter Confession Article VIII.5; and the Heidleberg Catechism $Q 11,12,14,15,17$ to prove his point and shows how even in Calvin the initiative in salvation is taken by the Father Himself.

\section{Reconciliation in the Nineteenth Century}

Distortions of genuine Protestant Christianity began quite soon after Luther as a spirit of contention led all Christian groups

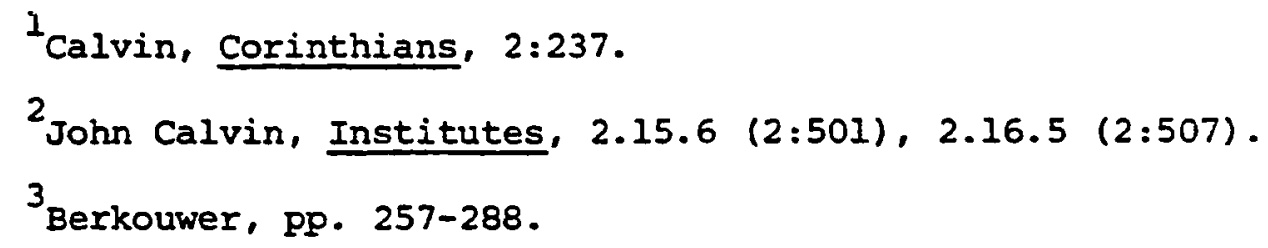


to identify themselves in terms of doctrinal purity. As the central religious reality of justification by grace through faith alone became converted by aggressive and ingenious minds into a series of dogmatic propositions, doctrine prevailed over life, and the gospel of free grace became a form of objective knowledge.

Albert Ritschl (1822-1889), one of the influential theologians of the nineteenth century, sought to recapture the deeply personal element inherent in Luther's idea of justification. To do this he took the term "reconciliation" and gave it a prominence it had never before had in Christian theology.

Reunion with God was shown to have a deeply personal and experiential character because of the dimensions of forgiveness and faith. Although justification and reconciliation were bound inextricably together they were not to be identified. If justification was effective it issued into reconciliation. Instead of the narrow scope traditionally ascribed to reconciliation in dogmatics, it was seen to be an expression of the actual result ever aimed at in justification, namely, that "the person who is pardoned actually enters into the relationship which is to be established." I Justification has a passive dimension to it so far as the sinners are concerned, but reconciliation has a more active component.

In giving reconciliation the place he did in theology, Ritschl was not altogether insensitive to the philosophic climate

IA. Ritschl, "The Christian Doctrine of Justification and Reconciliation," Vol. III, English trans. H. R. Mackintosh and A. B. Macaulay, eds., (Clifton: Reference Book Publishers, 1966), Pp. 85, 357, 78 in H. H. Ditmanson, Grace in Experience and Theology (Minneapolis: Augsburg Press, 1977), p. 156. 
around him. The distinctive needs revealed through the impact of events and movements within society at large made the theme of reconciliation particularly appropriate to the conditions of life in the nineteenth century. The age was one of ferment, confusion, revolution, and progress. Kenneth Latourette describes conditions ${ }^{1}$ at this time in terms of the effects of the industrial revolution. The ruthless exploitation of labor gave rise to long working hours, poverty accentuated by low wages, wretched housing, periodic unemployment, the menace to health and physical safety, intolerable conditions in crowded jails and prisons. The deterioration of morals in festering slums evoked angry assaults on the system of which they were a feature and on the failure of the Church to remedy them.

The series of scientific discoveries of this period seemed to give an aura of optimism and progress on the surface, but underneath it was accompanied by deep insecurity. The Darwinian theory provided ground for belief in a cold, relentless, and indifferent nature where man must struggle as best he can toward no particular goals other than those he himself was able to imagine. Paul Tillich points out that at the end of the nineteenth century people who were intensely sensitive to multiple estrangements of man "all seemed to live on the boundary line of insanity." 2 He mentions Nietzsche, Baudelaire, Rimbaud, Strindberg, Van Gogh, and Munch. They were

\footnotetext{
I Kenneth Scott Latourette, Christianity Through the Ages New York: Harper and Row, 1965), p. 237.

2 Paul Tillich, A History of Christian Thought, ed. Carl E. Braaten (New York: Simon and Schuster, 1967), p. 504.
} 
representatives and recorders, in an extreme sense, of the cleavage in the modern mind.

The theme of reconciliation was spelled out philosophically at this time by G. W. F. Hegel, economically by Karl Marx, and psychologically by Sigmund Freud, and showed the complete compatibility of Ritschl's concept to the climate of the age.

\section{Reconciliation in Contemporary Theology}

Contemporary theology has continued to use the concept of reconciliation as the answer to estrangement in this philosophic sense introduced by the nineteenth-century philosophers. The idea of God's atonement for man through Christ providing reconciliation between man and God sinks into the background, and the psychological, sociological, and political needs of the human race--reconciliation between man and man--has come to the foreground.

Early in the century men like James Denney, ${ }^{1}$ P. T. Forsyth, ${ }^{2}$ and Vincent Taylor ${ }^{3}$ sought to keep the Godward aspects of a substitutional, representative atonement central in the doctrine of reconciliation, but this has grown to be passe and, with the exception of Rarl Barth, completely out of favor with most contemporary theologians who conceive the church's mission to be that of a reconciling

IJames Denney, The Christian Doctrine of Reconciliation (New York: George H. Doran, 1918).

2P. T. Forsyth, The Cruciality of the Cross (London: Hodder and Stoughton, n.d.).

3 Vincent Taylor, Forgiveness and Reconciliation (London: Macmillan, 1948). 
agent in society. ${ }^{1}$ D. G. Miller expresses rather facetiously the

exasperation of many evangelicals at this trend when he says:

Reconciliation is often confined to the level of alienated human beings finally deciding to get along with each other, the appropriate hymn to celebrate the new relationships being the stanza frequently used to break the ice of social gatherings: When your friends are my friends And my friends are your friends The more we get together The happier we'll be.

Hamilton puts his finger on the theological shortcomings of this semi-humanistic approach when he points out that what has happenned is that "a biblical motif has found an extra biblical secularized equivalent." ${ }^{3}$ Man today tends to think of himself in categories of being parted from his own true seli and from a healing relationship with his fellows, rather than of being estranged from God because of his sin and all its ensuing consequences. Feuerbach's dogma that theology is actually anthropology stimulated the concept that in order to achieve reconciliation man must break down all the barriers alienating him. These barriers have been

${ }^{1}$ see, e.g., Arnold B. Come, Agents of Reconciliation (Philadelphia: Westminster Press, 1960); Dieter T. Hessel, Reconciliation and Conflict: Church Controversy over Social Involvement (Philadelphia: Westminster Press, 1969); Allen 0. Miller, ed., Reconciliation in Today's World (Grand Rapids, Mich.: Wm. B. Eerdmans Publishing Co., 1969); Georgia Harkness, The Ministry of Reconciliation (New York and Nashville: Abingdon, 1971.

2D. G. Miller, "God Reconciles and Makes Free," in Reonciliation in Today's World, ed., A. O. Miller (Eerdmans, 1969), p. 16.

${ }^{3} \mathrm{~K}$. Hamilton, "Reconciliation and the New Humanity," in Reconciliation in Today's World, p. 35. 
variously identified as different social, political, and economic forces. But whatever the cause of the problem, alienation is to be overcome through

- - strenuous effort directed at removing the causes binding man, individually and collectively, to his present estranged condition; and, once the impediments to reconciliation have been demolished, mankind will automatically find wholeness and harmony in a life of mutuality and freedom.

He goes on to point out that reconciliation can never be Christianity judged to be present in institutions or movements that seem to embody that general quality in a social, political, or economic sense. The Christian gospel affirms that reconciliation and the new humanity are both concrete actualities, already existing, brought by Jesus the Son of God. As Bonhoeffer remarks in his lectures on Christology: "Christ is the new creature. He thus shows all other creatures to be old creatures." 2

There are many recent theologians and churchmen, like the Catholic author Eugene Bianchi, who have endeavored to give a more sound theological basis and "radical rethinking of the theology of the rift" ${ }^{3}$ but still think of reconciliation as lying totally in the area of the church existing as a community of reconciliation ministering to a world of human alienations. They show the struggle between the Geneva architects in the World Council of Churches evident in the spirit of the Uppsala meetings and the basic evangelical segment of the church. This rift in theological approach

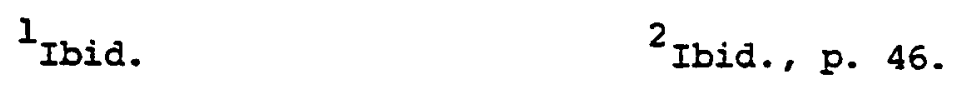

3Eugene C. Bianchi, Reconciliation: The Function of the Church (New York: Sheed and Ward, 1969), p. 4. 
seems to have been somewhat healed in recent years with the evangelicals' awakening sense of social responsibility ${ }^{l}$ and the world Council's return to a more biblical base. ${ }^{2}$

What still remains of concern to many evangelicals, however, is that even in this new return to a theological consideration for reconciliation between God and man as a basis of reconciliation between man and man, there is absent a biblical understanding of the atonement that affects that reconciliation. Typical of these is Georgia Harkness ${ }^{3}$ who sees Paul as having made two mistakes which have been transmitted to beset Christian theology through the centuries--an over-emphasis on the death of Christ to the exclusion of his life and ministry, and secondly, his virtual introduction of the doctrine of original sin as an inherited curse from Adam's disobedience. Berkouwer ${ }^{4}$ summarizes further views along these lines when he discusses the noetic subjective doctrine of reconciliation begun with Abelard and expressed in the moral influence theory of modern theologians such as Héring.

Such theologians see in the cross only a noble demonstration of Christ's commitment to His beliefs, a sign to move men to respond to God morally in a positive sense.

In considering this modern theology of reconciliation one cannot afford to neglect Karl Barth's massive treatment of this theme in the fourth volume of his Church Dogmatics. After exegeting

${ }^{1}$ J. D. Douglas, ed., Let the Earth Hear His Voice (Minneapolis: World Wide Publications, 1975), p. 4.

2 Ibid. $\quad 3$ Harkness, p. $40 . \quad 4$ Berkouwer, Pp. 273-275. 
the most significant biblical passage on reconciliation (2 cor 5:19), Barth then goes ahead to construct a whole Christology, harmatology, soteriology, and ecclesiology around this theme. Commenting on this, Berkouwer ${ }^{l}$ feels that while Barth avoids the shallowness of the noetic subjective doctrine of reconciliation, he almost seems to reveal the opposite extreme of universalism in trying to maintain that "if one has died for all, then are all dead." According to Barth, Paul's statement "Be ye reconciled to God" does not refer to - - an extension of the atonement in the form of something man himself can decide. . . . It is a request for openness, the attention and the obedience which are needed to acknowledge that what has happened in Christ, has really happened, to enter the only sphere which is now left to man, that of the new, that of the conversion to God which has taken place in Christ.

Berkouwer also accuses Barth of patripassionism ${ }^{3}$ (the doctrine that God the Father suffered and died in a redemptive way usually ascribed to (hrist) in such passages as his exegesis of "God was in Christ reconciling the world unto himself," and this accusation is spelled out again by klooster ${ }^{4}$ in terms of modalism (the doctrine that the one God revealed himself at different times in different modes; sometimes as the Father, sometimes as the Son, and sometimes as the Holy Spirit, but always it is the one God). It appears clear from this that despite Barth's impressive and original theology of reconciliation, there are aspects of his work that are subject to misunderstanding. He effectively implies that the incarnation is itself the reconciliation. It becomes evident that

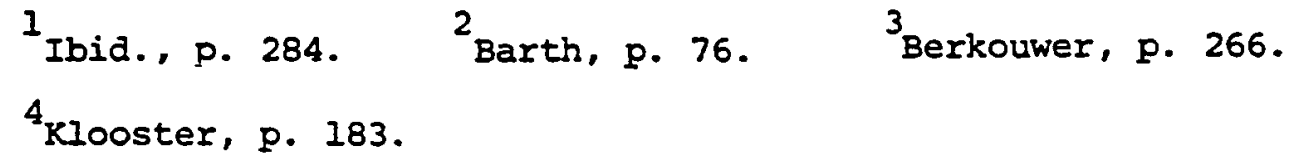


"Barth rejects the penal substitutionary theory of the atonement (p. 253) and that involves the rejection of what touches precisely the heart of scripture. "I

While the moral influence on men of the atonement is not denied by evangelicals today, and much of what Barth has said can really be appreciated, the flat denial of any substitutionary representative function in Christ's death is still resisted by a core of evangelical scholars. Foremost among these is Leon Morris, who with all the tools of modern biblical scholarship establishes the truly forensic base to the doctrine of reconciliation.

Although Morris does not adopt the radical Calvinist position that God hates all sinners and can only be placated in his wrath by the propitiatory sacrifice of Christ, he nevertheless points out how in a real sense sin has alienated God from man and that God needs to be reconciled to man as well as vice versa. Morris recognizes that when the New Testament is allowed to speak for itself that God is never said in so many words to be reconciled to man, but from a consideration of the terms "enemies of God" and "making peace" he shows that it cannot be maintained that there is no enmity from the side of God. "The point is that it is God's demand for holiness which causes the enmity, and not a conscious hostility on the part of man toward God." 2 Morris maintains the initiative of God in the act of reconciliaiion and shows how the love of God revealed supremely through the atonement is not to be set over against his wrath at man's sin but exists alongside

$I_{\text {Ibia }}$. 2Morris, p. 223. 
it. Neither negates the other; rather a creative paradoxical tension is maintained.

This is further supported by Buchsel who points out that - - in Rom 1:18-32 Paul speaks quite plainly of the wrath of God as a present and manifest reality, though His patience is also manifest and operative $(2: 2,5 ; 3: 26)$. . . Thus the God who reconciles, us to Himself is always at the same time the God who judges us.

Even though estrangement between man and God is described as enmity, this is to be thought of as an objective condition rather than an emotive hatred of God or man to the other. Divine wrath here in Paul's mind is the reaction of holy love to sin and secular attitudes.

James D. G. Dunn further refines the forensic concept spelled out by Morris and others like Nicole and D. Hill who retreat from C. H. Dodd's total rejection of all propitiatory significance for the word group in the Ixx. He points out that any thought of punishment, although legitimate, is secondary. "The wrath of God in the case of Jesus' death is not so much retributive as preventative" ${ }^{2}$ aimed at the destruction and expiation of the malignant, poisonous organism of sin. Another refinement he makes is to point out how "substitution" is too narrow a word, having individualistic connotations. "Representative" is a better word. "for as we have seen, in Paul's theology, Jesus represents man, not just a man, on the cross." ${ }^{3}$

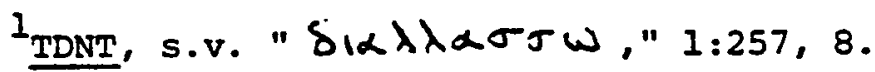

2J. D. G. Dunn, "Paul's Understanding of the Death of Jesus," in R. J. Banks, ed., Reconciliation and Hope (Exeter: Paternoster Press, 1974), p. 139.

3 Ibid. , p. 141. 
It is important to realize that the cross had cosmic dimensions affecting the reconciliation of the universe as well as man. Paul deals with these in Colossians where he talks of reconciliation and forgiveness in terms of victory over the spirits of the universe. ${ }^{1}$ Reconciliation is extended to beings other than man and the emphasis is here on moral perfection as the ultimate outcome.

Different aspects of the reconciliation theme can be gleaned from the writings of Matthew ${ }^{2}$ and $\mathrm{John}^{3}$ where the significance of atonement is considered from different viewpoints, but one cannot escape the fact that a representative forensic atonement lies at the basis of any biblical understanding of reconciliation, whether the strictly law-court imagery of justification is used or not.

\section{An Integrated View}

Leon Morris has reacted intelligently to the excess use of reconciliation in modern theology when he points out the comparatively few occasions in the New Testament when the term is actually used. Reconciliation is not as central as justification or love, for example. This does not mean that reconciliation is not important. "Though the passages in which it is mentioned are few they are highly significant. We should not overestimate them, but

$I_{R}$. P. Martin, "Reconciliation and Forgiveness in colossians," in Reconciliation and Hope, pp. 104-124.

2B. Gerhardsson, "Sacrificial Service and Atonement in the Gospel of Matthew," in Reconciliation and Hope, pp. 25-35.

${ }^{3} \mathrm{~J}$. Painter, "Eschatological Faith in the Gospel of John," in Reconciliation and Hope, pp. 36-52. 
neither should be minimize them."I Although from a Biblical point of view there are several passages that deal with reconciliation in terms of its practical implications in the lives of men (Matt 5:23, 24; 1 Cor 7:11; Eph 2:11-19), the main passages that deal with the essence of reconciliation from God's point of view are 2 Cor 5:1421, Rom 5:6-11, and $\operatorname{col} 1: 20-22$. It is profitable to briefly examine each of these passages and distill their central meaning as an integrated view is sought.

". . one has died for all; therefore all have died" (2 cor 5:14)

The first thing that becomes apparent is that reconciliation has a forensic base and rests on the legal concept of justification by faith alone. Buchsel makes this quite clear when he says that "reconciliation included justification." I The Interpreter's Bible assumes that the preposition "for" (unep) here means "for the benefit of others." 2 The full force of this text is only realized, however, when it is understood that the "for" here does not mean in this instance "for the sake of" but rather "instead of."

Since Christ has died for all and in the place of all, all are dead. Christ on the cross incorporated all men within himself, and represented all. Hence the death of christ is also the death of all mankind. In Christ, the verdict of God's judgment was pronounced on all, as upon sinners who were lost, and in this way judgment was executed upon all. All men can truly say: "I am crucified along with Christ" (Gal 2:19).

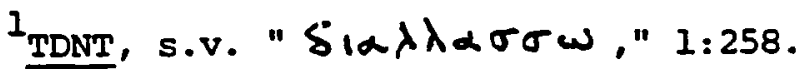

${ }^{2}$ F. V. Filson, The Interpreter's Bible, 12 vols. (New York: Abingdon, 1953), 10:334.

$3_{K}$. Schelkle, "The Second Epistle to the Corinthians," in The New Testament for spiritual Reading, ed: J. C. Mckenzie (New York: Herder \& Herder, 1969), p. 82. 
"For this reason reconciliation included justification. . . Yet as the kindling of love it embraces more than the removal of guilt in forgiveness." 1 Following convincing arguments, which are soundly documented, that the context here requires substitutionary understanding, Hughes asserts: "To interpret Christ's death as being merely exemplary or in some general sense as for the advantage of men, as an assurance of God's good will notwithstanding man's rebellion, is to destory the mainspring of the apostle's argument." 2 "The belief that Christ died representatively on behalf of the whole human race is the key principle of Paul's theology." ${ }^{3}$ This puts God's great act of reconciliation with man outside of each man and any faith response by man. " . . God did something of infinite and objective importance for the world regardless of whether it is appropriated by the individual or not." 4 In a very real sense every human being has paid his debt to $\sin$ in A.D. 31 when his representative died. This does not mean universalism, however, for it remains for man to accept his reconciliation (2 Cor 5:20). "Man carnot accomplish his reconciliation with God, but he can refuse it." 5

$1_{\text {TDNT, }}$ "Sla $\lambda \lambda_{\alpha} \sigma \sigma \omega, " 1: 257,258$.

2P. E. Hughes, Paul's Second Epistle to the Corinthians (Grand Rapids: Eerdmans, 1962), p. 193. See also C. K. Barrett, A Commentary on the 2nd Epistle to the Corinthians (New York: Harper \& Row, 1973), p. 168; R. H. Strachan, The Second Epistle of Paul to the Corinthians (London: Hodder \& Stoughton, 1954), p. 107.

3. E. Thrall, The First \& Second Letters of Paul to the Corinthians (Cambridge: The University Press, 1965), p. 149.

4W. M. Aldrich, "The Objective Nature of Reconciliation," Bibliotheca Sacra 118 (January 1961): 18.

5J. F. Walvoord, "Reconciliation," Bibiotheca Sacra 120 (January 1963): 4 . 


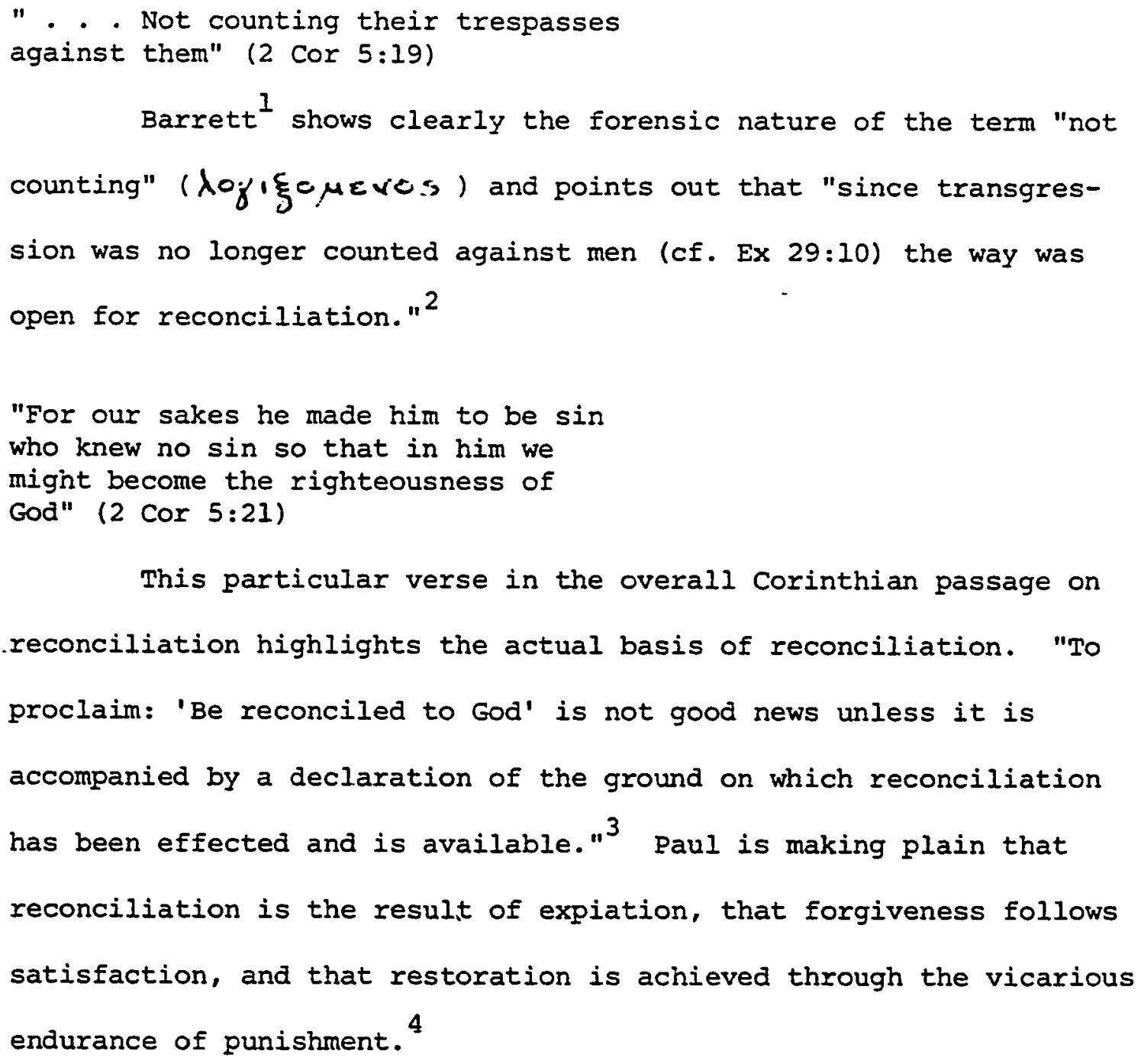

${ }^{1}$ C. K. Barrett, A Commentary on the Epistle to the Romans (New York: Harper and Brothers, 1957), p. 110.

${ }^{2}$ C. K. Barrett, Corinthians, p. 177.

3 Hughes, p. 211.

${ }^{4}$ See also Barrett, Corinthians, p. 180; C. Hodge, Second Epistle to the Corinthians (London: Banner of Truth Trust, 1959), p. 135. 
"Therefore since we are justified by faith we have peace with God through our Lord Jesus Christ" (Rom 5:1)

The peace here spoken of resulting from our justification is not primarily an experiential inner peace, although it will surely issue into that in a limited way. The apostle is concerned with our "whole relationship and state and not with our subjective feelings". ${ }^{1}$ The word peace is here primarily a martial term. Previously we were enemies of God because of our sin, but now the alienation and estrangementare over. The hostilities have ceased. God is no longer our "antagonist" in a judicial sense. Justification puts an end to the legal strife between the Judge and accused. No more than justification is "peace" an experience; it is an objective status or condition, $a_{2}$ relation which exists between God and those whom he justifies.

"For if while we were enemies we were reconciled to God by the death of his Son..." (Rom $5: 10)$

This verse emphasizes again that reconciliation comes "by" the death of Jesus. Paul's line of thought is here closely connected with being "justified by his blood" (vs. 9); "while we were yet sinners Christ died for us" (vs. 8); and "since we are justified by faith we have peace with God through our Lord Jesus Christ" (vs. 1) that come in the preceeding verses. Noticing the structural parallelisms between verses 9 and 10, both Barrett and Murray point out that "Justification and reconciliation are different metaphors

ID. M. Lloya-Jones, Romans (London: The Banner of Truth Trust, 1971), p. 143.

2 Barrett, Romans, p. 101. 
describing the same fact," ${ }^{I}$ and that "reconciliation must be interpreted in forensic terms. Otherwise the parallel would break

down. $" 2$

". . you ... he has now reconciled

in his body of flesh by his death, in

order to present you holy and blameless

and irreproachable before him"

(Col $1: 21,22)$

This verse again brings out the fact that it was the death of Christ that effected reconciliation on a substitutionary basis. It is the last clause that makes it especially clear that the death of Christ achieved this-not by way of example-but in such a way as to present man "holy and blameless and irreproachable" before God. This is a clear reference to the forensic nature of Christ's work. "The thought is of the blessed Body not generally, as regarding the incarnation, but particularly, as regarding the Propitiation." 3 The Colossians were to recall that their restoration was rooted in Christ's death. "The means of their reconciliation was the Son of God who by means of death effected the return to that status of fellowship with God for which he had created man and from which they had fallen." 4

This brief survey of the forensic nature of reconciliation

I Ibid., p. 108.

2 J. Murray, The Epistle to the Romans, 2 vols. (Grand Rapids: Eerdmans, 1952), 1:172.

3. C. G. Moule, Epistle of Paul the Apostle to the Colossians and to Philemon (Cambridge: University Press, 1906), p. 87.

${ }^{4}$ H. M. Carson, The Epistles of Paul to the Colossians and to Philemon (Grand Rapids: Eerdmans, 1960), 0. 48. 
has not been a purely academic exercise. It has critical importance in understanding the essence of reconciliation, especially as it relates to who was reconciled to whom. Some ${ }^{I}$ would maintain that God did not need in any way to change His relationship with man; that only man needs to change his attitude toward God. The scripture is very plain, however, that there is a very real sense in which God's wrath against man's sin had to be propitiated and expiated before He could reconcile man to Himself.

"All this is from God, who through Christ reconciled us to himself. . . God was in Christ, reconciling the world to Himself (2 Cor 5:18, 19); "While we were enemies we were reconciled to God" (Rom 5:10)

These verses emphasize the initiative of God in the act of reconciliation. Man is hostile to God. He neither obeys nor trusts Him but demands complete independence and wants to go his own way. It is this fact that makes it necessary for God to take the initiative. In his natural state man neither sees his need of reconciliation, desires it, nor is capable of affecting it. By sin man sets himself in rebellion against God; he becomes an enemy of God and is alienated from him. One must realize the deep radical nature of sin and its power over mais to fully appreciate the dimensions of God's initiative in affecting reconciliation. $\sin$ is the revolt of man both against God his Creator and also against his own constitution as creature. Thus Rom 5:10 says while we were "enemies" we were reconciled to God.

${ }^{1}$ See Reconciliation in the Nineteenth Century, p. 15 of this chapter. 
Reconciliation consequently has a double depth to it. ". . It is He who reconciles us, and it is to Himself that he reconciles us. Reconciliation proceeds from God and returns to God." I Hence the act of reconciliation substantiates the fact that God was not a helpless victim of the mutiny of man. God meets man's rebellion actively in two ways; by showing His wrath against sin, yet doing it in a way that also showed His love for man. It is God's "Divine aggression," says Strachan. 2 This presents a paradox which cannot be evaded. The one event reveals the exhaustion of God's wrath against sin and His surpassing love for man. It is at the cross that "love and wrath meet in a common purpose, that mercy combines with truth and righteousness and peace kiss each other (Psa 85:10; Rom 3:26)." 3

Another important point that emerges out of considering these passages is that God's reconciliation to us is not an ongoing process. It is rather "viewed as something accomplished ance for all in the death of the Son of God." 4 His reconciliation to us was an act that took place in a point of time in the past. We "were" reconciled to God, says Paul (Rom 5:10).

It is true that in the book of hebrews Jesus is portrayed in the role of High priest carrying on a continual ministry that facilitates the access of man to God. In view of the high priestly ministry of Jesus men and women are urged to "come boldly to the

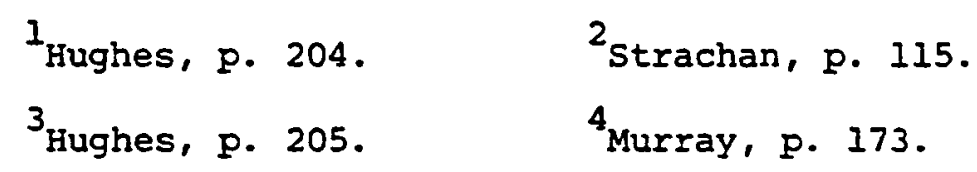


throne of grace"l and "draw near with a true heart in full assurance of faith." ${ }^{2}$ This is language describing a reconciled state. The alienation existing between man and God is expressed in Hebrews in terms of the veil which ever kept men from having access to God until the time of reformation came when Christ entered into the presence of God, having obtained eternal redemption for us. ${ }^{3}$ We now have confidence to enter into the presence of God (symbolized by the Most Holy Place) by the blood of Jesus, by a new and living way opened to us through the curtain, that is, His body. 4

There is a very real sense in which the present ongoing ministry of Jesus contributes to man's reconciliation with God and no attempt is made to minimize that fact. But at the same time that ministry rests solidly on His once-for-all act of reconciliation. It would be completely without force had that act on the cross not taken place in point of time in a once-for-all-time manner and been efficacious for all time. It is in this sense that God's reconciliation to us can not be thought of as an ongoing process. The high priestly ministry of Christ does not mitigate the finished nature of God's act of reconciliation any more than the completed nature of reconciliation mitigates the need for a continuing high priestly ministry by our Lord.

The scope of this act of reconciliation must of necessity be universal. Comparing 2 Cor 5:18 and 19, Barrett observes: "The only new thought. . Is that 'us' is expanded into 'the world'; this

$1_{\text {Heb }} 4: 16$ (unless otherwise stated all Biblical references are taken from the New International Version).

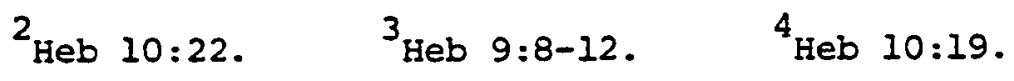


says no more than verse 14 , he died on behalf of all. . It was a whole world He reconciled, including perhaps the rebellious heavenly powers of col 1:19f." 1 God has thus offered all men total unconditional acceptance while they were "sinners", "ungodly", and "enemies". This is demonstrated in many of Christ's interchanges with men and women in the Gospels le.g., the paralytic, the woman taken in adultery, the thief on the cross).

The extent of this "all" is contested by many Calvinistic theologians who want to limit it to "the innumerable company of those who would enjoy the benefits of his redemption." ${ }^{2}$ According to Hodge: "He did not die for all creatures; nor for all rational creatures; nor for all apostate rational creatures. The all is of necessity limited by what the scriptures teach of the design of his death." ${ }^{3}$ Hughes, however, shows how Paul's use of the Aorist verb is critical here.

The two Aorist verbs-"one died . . . all died"-point back to one event, namely the crucifixion of Christ. A passage which is complementary to this is Rom 5:12ff., where the apostle teaches that when one man Adam sinned, death, the penalty of sin, passed onto all men on the ground that all sinned, that is were identified with Adam in his sin. In the case of both Adam and Christ, one action has had consequences of universal significance, and the involvement of all men in the action of each is a real involvement.

This chapter has traced in an historial sense the development and understanding of the concept of reconciliation from old

${ }^{1}$ Barrett, Corinthians, p. 177.

2R. V. G. Tasker, The Second Epistle of Paul to the Corinthians (Grand Rapids: Eerdmans, 1960), P. 84.

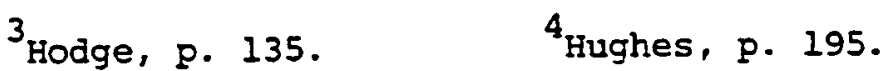


Testament times to this present day. The close relation between the cultic forms of atonement in the old Testament and reconciliation gave way to a legalistic man-centered means of breaking down alienation with God during Intertestamental times. In the New Testament Paul spelled out the forensic base to God's great act of removing the enmity that existed between God and man and vice versa, but this was rapidly lost sight of during the patristic period. The seeds were sown at this time for a sacramental form of reconciliation that came to full bloom in Aquinas and Tridentine theology. The Protestant reformers being preoccupied with the forensic nature of justification, did not place much emphasis on its final effect, but Calvin especially laid the groundwork for reconciliation to emerge in this respect. The nineteenth century saw a surgence of humanistic concepts relating reconciliation to the social order, but today there is still a solid core of evangelical scholars who maintain the objective nature of God's completed act of reconciliation whereby the enmity existing between God and mankind was removed in Christ. This does not mean that reconciliation has no subjective consequences, and it is to these that chapter III now turns as the implications of this theology to ministry are spelled out in terms of human experience. 
CHAPTER III

\section{RECONCILIATION IN MINISTRY}

In chapter II we have seen how the concept of "reconciliation," although not a dominant theme in the scriptures, is nevertheless a powerful model for integrating much that is involved in man's salvation. This theme has become especially relevant in modern times where alienation and estrangement characterize all aspects of society and life. The implications of a theology of reconciliation to ministry may be summarized by the following schema:

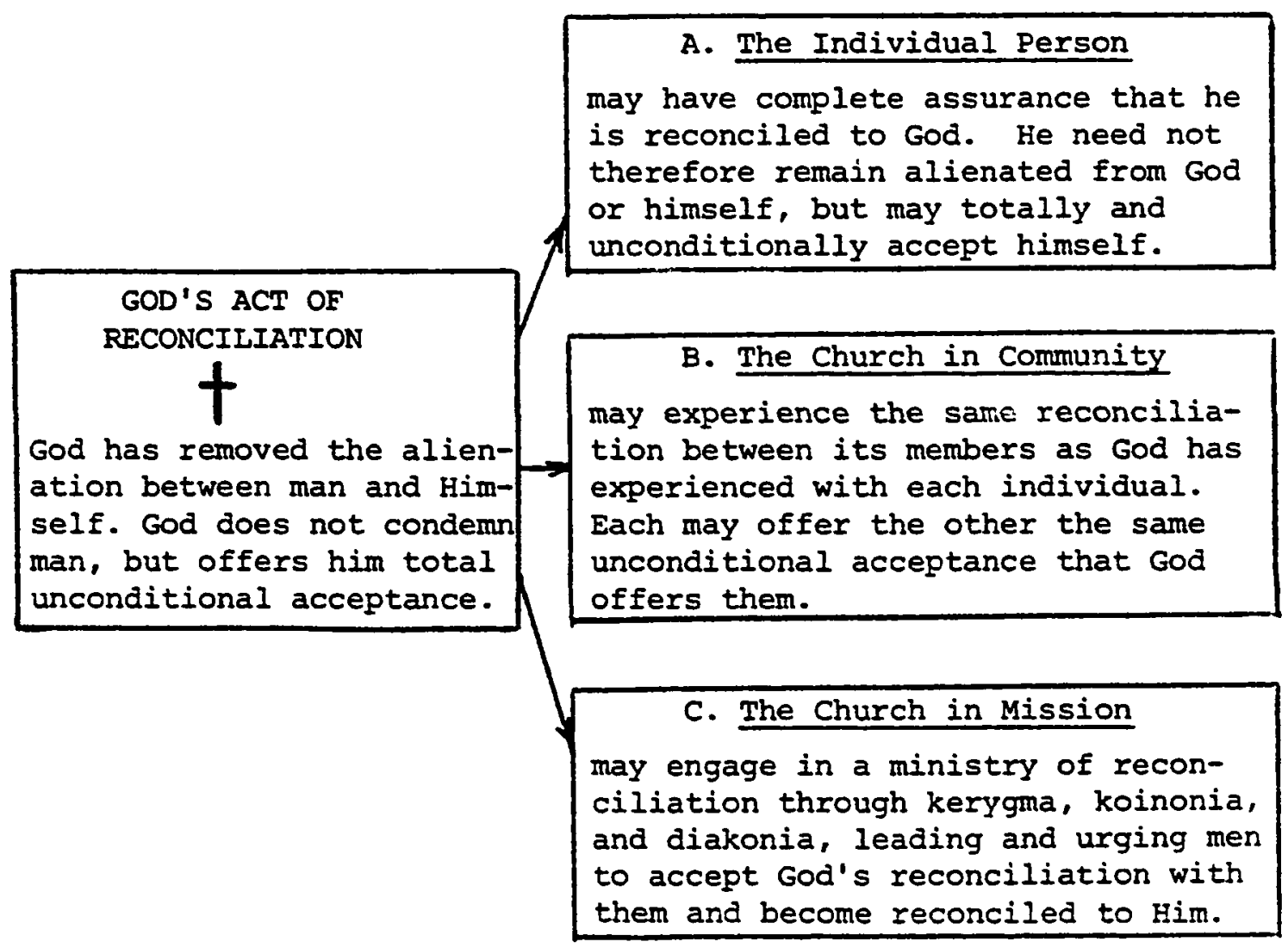

36 
The Individual Person

Modern man is alienated from God and himself. After describing the horrors of his and others' existence in the German death camps during World War II and his struggle to find meaning in life in the face of all that entailed, Victor Frankl describes what he calls an "existential vacuum" I as a widespread phenomenon in the twentieth century. Instead of being motivated to act by instinct, tradition, or even desire, men and women either wish to do what other people do (conformism) or do what other people wish them to do (totalitarianism). Despite this Frankl still tends to be optimistic about man believing that this vacuum does not "wipe out man's search for meaning, however, which is a 'primary force in his life and not a secondary rationalization of instinctual drives." 2

Many today, however, seem to have even given up that search for meaning and integration and, instead, have resigned themselves to a bleak existential despair. The despair is heightened by a consciousness of their human potential that serves to emphasize an inner dichotomy. Describing this condition of man Eric Fromm expresses the anguish of a dilemma in which man's "own existence is a problem which he has to solve and from which he cannot escape." 3 Man has no say over his birth or death yet he is aware of himself, with all the powerlessness and limitations of his existence. He knows that one day he has to die and yet his body makes him want to

\footnotetext{
IV. E. Frankl, Man's Search for Meaning (Boston: Beacon Press, 1962), pp. 107, 8 .

2 Ibid., p. 99.

3E. Fromm, Man for Himself (Greenwich: Fawcett, 1969), p. 49.
} 
be alive. In grappling with this insoluble dichotomy he cannot rid himself of his mind and thus reason, man's blessing, turns out also to be his curse. Man must live, and because this existence is a problem which he has to solve and from which he cannot escape, he is in a state of constant and unavoidable disequilibrium.

By considering observable attitudes of: (1) giving and getting affection, (ii) evaluation of the self, (iii) self assertion, (iv) aggression, and (v) sexuality, Karen Horney noticed in 1937 that neurosis in society was really only a matter of degree. The recurring problems of neurotic persons "differ only in quantity from the problems bothering the normal persons in our culture." 1 Problems of competition, fears of failure, emotional isolation, distrust of others and ourselves are common to all reople. This lays the basis of what she called "the neurotic personality of our time" which she attributed to a deep seated need for "genuine warmth and affection, $" 2$ for acceptance instead of "cruel rejection." ${ }^{3}$

Forty years after Horney, Christopher Lasch changes the metaphor from "neurosis" to "Narcissism"; a complex term describing sociological and psychological withdrawal into self from reality. Contemporary man has chosen narcissism as the best way of coping with the tensions and anxieties of modern life. 4 Drawing psychological analogies from the reference in the second chapter of Ephesians to the two strangers, Anne Ulanov sums up this whole condition

$I_{K}$. Horney, The Neurotic Personality of Our Time (New York: w. W. Norton, 1964), p. 74 .

2 Ibid., p. $80 . \quad 3$ Ibid., p. 84.

${ }^{4}$ C. Lasch, The Culture of Narcissism (N.Y.: Warner, 1979), p. 101 . 
of mankind eloquently when she says:

This passage . . . strongly calls to mind our own inner suffering from estrangement within ourselves, where our hopes pull one way and our despair another, where what we know to be the case is so different from what we want to be the case, where 1 our outer public face conflicts with our real inner condition.

Francis Schaeffer has well-documented the way contemporary philosophy, art, literature, drama, music, cinema, photography, and all similar forms of subjective expression reflect the inner alienation within man and its consequent fruitage of meaninglessness, hopelessness, and despair. Illustrating this thesis with a modern pornographic work, he gives a typical example in which a woman puts herself into the hands of a man to be beaten explicitly because she believed no God existed. ${ }^{2}$ she wanted to be possessed by someone and thus in her alienation was glad of the beatings and pain as a proof of possession by something, someone.

Maurice Wagner points out from a Christian perspective how the reality of this alienation is discovered early in life by children when they become separated from their parents. He asserts that this was God's way of getting humans to realize they are separated from Him because of sin. "We have been filled with terror at the thought of being separated, isolated, and alone. Such feelings imply rejection as a non-entity, a nobody." ${ }^{3}$ Whenever people are godless in their living and employ self-verification as a means of

${ }^{1}$. B. Ulanov, "The Two Strangers," Union Seminary Quarterly Review 28 (Summer 1973):273, 4 .

2F. A. Schaeffer, Escape from Reason (Downers Grove: Intervarsity Press, 1972), p. $6 \overline{6}$.

${ }^{3}$ M. E. Wagner, The Sensation of Being Somebody (Grand Rapids: Zondervan, 1975), p. 145. 
being somebody, then, he maintains, they actually are a non-entity having no self-identity.

Over against this all-pervading experience of mankind's alienation and estrangement from God and from himself, the Scripture presents the reality of reconciliation and integration:

We also rejoice in God through our Lord Jesus Christ, through whom we have received our reconciliation (Rom 5:11)

For through him we both have access in one spirit to the Father (Eph 2:18)

Be reconciled to God $(2$ Cor $5: 20)$

Therefore if anyone is in Christ he is a new creature, the old has passed ( 2 Cor $5: 17$ )

The love of God controls us (2 Cor 5:14)

And he died for all, that those who live might live no longer for themselves but for him who for their sake died and was raised (2 Cor 5:15)

Provided that you continue in the faith, stable and steadfast, not shifting from the hope of the gospel which you heard (Col $1: 23$ )

And having a high priest over the house of God; let us draw near with a true heart in full assurance of faith (Heb 10:21, 22)

\section{Assurance of Salvation}

The truth emerging strongly from these passages is that in view of the tremendous implications of the fact that historically in the death of Christ, God has reconciled man to Himself, the logical invitation--even imperative--resting on man is to accept his acceptance and become reconciled to God. Reconciliation is a "status once for all received and since it has been received we are to recognize the implications of this standing before God." ${ }^{1}$ The

\footnotetext{
${ }^{1}$ Murray, p. 176.
} 
now in Rom 5:11 "describes the anticipation in the present of God's verdict at the judgment." 1 There is no reason at all why the individual should stay in an estranged relationship to God or doubt God's unconditional acceptance of him. God's act of reconciliation has the power to bring assurance of his salvation to the individual because it rests in a completed historical action outside of himself, rather than a subjective experience within him. Any inner experience is always an ongoing process and lacks the finality and certainty of a "once-for-all-time act" of God demonstrated at the event of reconciliation.

Christ has in His act ushered in a new creation. Old things are passed away. In the person of Jesus Christ we see all that the new mankind is. Possessing eternal life, absolute peace, and perfect righteousness, Jesus' life on earth was an undeniable demonstration that the kingdom of God and all that the old Testament prophesied of the Messianic age was indeed in our midst at last. The newness of Jesus' mission did not really lie in his teaching. It was the nature of the event that constituted the newness. It brought to men an "actual foretaste of the eschatological salvation." ${ }^{2}$ In forgiving of sins, inviting men into fellowship with Himself, bestowing righteousness and delivering men from sickness and death, Jesus demonstrated the present existence of the Kingdom of God and Himself as its bearer.

1 Barrett, Romans, p. 109.

2G. E. Ladd, The Fresence of the Future (Grand Rapids: Eerdmans, 1964), p. 216 . 
The subjective experiential application that many commentators make of the expression: "If any man be in Christ he is a new creature"I does not hold up under exegesis. "The eschatological interpretation of the phrase advocated there is the only one that makes adequate sense of the present passage." 2 strachan has adequately expressed the significance of this latter concept when he says that the condition of being "in Christ" is 'Jeing in a "new world," a "new creation." Paul bases this whole concept on the Jewish doctrine of the two "ages" or "aeons" in which this present age, this world (Gal $1: 4 ; 1$ Cor $2: 6$ ) is under the sway of evil powers (2 Cor 4:4; Eph 6:12), while the age to come (Eph 1:21; Iuke 18:30) constitutes life when the Kingdom of God is ushered in. This teaching was not new with Paul; it was drawn directly from Jesus' own teaching (Luke $11: 20$ ). It is in this framework that one must think of what it means to be "in Christ". "The creature is new because the Creation, or world in which he moves, is new (Gal $6: 15) .1^{3}$

This does not mean, however, that there is no subjective impact on the individual as he begins to live in the new creation. ". . as a man-in-Christ he is in fact a new creation-a reborn microcosm belonging to the eschatological macrocosm of the new heavens and the new earth." 4 If anyone is "in Christ", that is, has accepted the reconciliation offered to him by God, then, 2 Cor

Isee Tasker, p. 88; The Interpreter's Bible, 10:338.

2 Barrett, Corinthians, p. 173.

3 strachan, pp. 113, 114. 4 Hughes, p. 201. 
5:15 points out, he may share in that new creation. Until the time of the consumation he still lives in this present age, the old creation, but that still does not detract from the possibility and privilege of exploiting to the full his legitimate heritage of the new creation. It is concerning this that Paul prays in Eph $1: 18$ : "The eyes of your understanding being enlightened; that ye may know what is the hope of his calling and what the riches of the glory of his inheritance." It is this concept that provides the starting point and basis for dealing with all forms of inner alienation and estrangement of the self. It provides the individual with a mechanism for dealing with guilt in its various rational and irrational manifestations.

In a perceptive study on guilt Paul Tournier speaks of three types of guilt experienced by man: a genuine guilt resulting from a known violation of moral standards; a false, irrational guilt experienced as a type of neurosis for which there is no legitimate cause; and a general, all-embracing moral guilt of which all men are held responsible by God whether they realize it or not. ${ }^{l}$

God's act of reconciliation gives man a way of handling all three of these forms of guilt. Man's genuine individual guilt and his universal moral guilt are both expiated by Christ's representative death. But the neurotic, false guilt man often takes upon himself because of his inner alienation also has the axe laid at its roots as man comes to see that through the cross God offers him

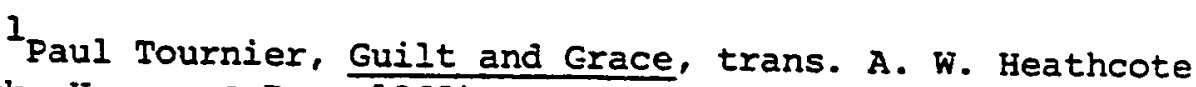
(New York: Harper \& Row, 1962), pp. 63-71. 
complete, total, unconditional acceptance no matter what his past sins, real or imaginery, may have been.

\section{Psycho-Emotional Stress}

Similar to the irrational type of guilt that becomes deeply embedded in the psyche of many people, there are other psychological disorders of a similar nature resulting in a disintegration of the self. These range on a spectrum all the way from a fuzzy concept of self-identity through neurosis to psychosis. Almost invariably these conditions stem from a feeling of or experience of rejection, alienation, and lack of self-worth in some way or other, whatever their cause may be.

It would be simplistic and false to suggest that a mere preaching of God's act of reconciliation cures these disorders, thus obviating any need for psychotherapy. But what is being suggested is that God's act of reconciliation provides a matrix and a goal for any therapy. The only real hope the disintegrated person has is that he "really" hears about the present existence of the new creation and his privilege of participating in it. It is the task of the therapist to help remove any roadblocks to that perception and help the individual deal in a constructive way with issues that may be hindering him in a psycho-emotional way from appropriating his already God-established state of reconciliation. Once the "indicative" of his relationship with God is grasped, then the "imperative" of living out of that relationship becomes much easier. Anne Ulanov expresses the futility of purely secular psychotherapy and this necessary base of reconciliation when she says that 
mental health is "not achieved if it is made a goal or an end in itself. Even in the course of therapy it comes about as a mere byproduct."I It is a by-product, she says, of a relationship to something beyond itself, the person of Christ. If mental health is pursued apart from this, people only get in touch with their own psyche--theix own version of mental health--and that only proves to be a caricature of real health.

And as Wagner draws to our attention, we only find in God, as the Bible describes Him, all those attributes we need for peace of mind and an emotionally mature sense of self-identity. Those attributes are "almighty sovereign, realism manifested in perfect justice, unconditional love manifested in grace and mercy." 2

In a similar way God's act of reconciliation provides a basis for dealing with all forms of grief as it springs from personal loss in areas such as death, divorce, work, and children leaving home. Without suggesting that a grasping of God's act of reconciliation waves a magic wand over the processes of grief and offers a person freedom from the dynamics of personal loss, it is still true that knowledge of and application of this great fact places the grief sufferer in an entirely different relationship to his loss and gives him a basis that no other person has to cope with and work through his grief.

God's act of reconciliation reveals the truths we need to hear in times of loss: that God is for us and not against us, and that he is also for the persons we have lost and not against them.
Iulanov, p. 283.
2 wagner, p. 143. 
Even if we through our mortality and sinfulness have caused irretrievable and irreversable harm to life and relationships, or whether the loss is a natural or tragic phenomenon of life, it still remains true that God's plans and providence for us are always ones of beneficence. The nature and magnitude of God's act of reconciliation becomes an anchor to that immutable fact and gives sorrowing man a perspective and meaning, similar to Frankl's logotherapy, that can help him work his way through the grief and come to terms with his loss. The person who accepts his reconciliation does "not grieve as others do who have no hope" (1 Thess $4: 13$ ).

As Paul said in 2 cor 5:14, the love of Christ controls or constrains a person upon whom the magnitude of the fact that "one has died for all; therefore all have died" has been fully understood and grasped. The response is not one of libertinism or antinomianism but a complete captivation of the emotions in gratitude and love. Paul's regular paean of praise that spontaneously breaks forth whenever he finishes considering the nature of God's reconciling work (e.g., Rom 8:31-39) is the natural response of every soul who grasps the same truth and steadfastly continues in the hope of the gospel. Even Frankl in his secular logotherapy la form of experiential psychotherapy centering around an inherent need for meaning and values in human life) grasped that this can be the only way to really deal with any problem situation. Values do not drive or push a person; they rather pull him. Man does not behave morally for the sake of having a gocd conscience but "for the sake of a cause to which he commits himself, or for a person whom he 
loves, or for the sake of his God." I

The realization that legally in God's eyes we died in A.D. 31 with the death of Christ enables us to see that not only have we paid the penalty of death for our sins through our representative, but that we no longer need live for our disintegrated selves (2 $\operatorname{cor} 5: 15)$. We are now freed to live for Him who has reconciled us on the level of the new creation. There now "exists the universal possibility . . of a new kind of human existence, no longer centered upon self but centered upon christ." 2

Thomas oden provides a useful model in the first thirteen chapters of his book The structure of Awareness ${ }^{3}$ for dealing with the personal implications of reconciliation in a way that incorporates much of what has been said here in the first section of this chapter. If God has no place in our value system (chapter 12), invariably we deify finite contextual values in His place. Things and other values take the place of a transpersonal (I-Thou) relationship. When God's act of reconciliation is perceived, faith in God beyond the pseudo-gods is awakened and idolatry is shattered. The self (chapter 13) comes to the place where instead of experiencing despair because of impotence in actualizing itself. it achieves a totally new self-image as a result of reconciliation. Perceiving the depth of God's act of reconciliation enables the individual to gain a totally new perspective of his own personal

IFrankl, p. $101 . \quad$ 2.arrett, Corinthians, p. 169. don, 1969).

${ }^{3}$ T. C. Oden, The Structure of Awareness (Nashville: Abing- 
value in God's eyes. This has a tremendous impact on self-esteem. The individual sees his right to be a part of the new creation ushered in by Christ. He begins to discover himself and all the potential of his God ordained actuality, including spiritual gifts to carry out his role in the mission of the church. This new identity gives the individual a sense of affirmation and enables him to rise above the lostness and despair of identity diffusion that previously existed.

The security coming to the individual resulting from the unconditional acceptance offered him through God's act of reconciliation enables him to deal with guilt from the past (chapters 1-5), anxiety about the future (chapters 6-8), and boredom in the present (chapters 9-11). The memories of past relationships that produced guilt and alienation lose their tyrannical nature. In the reconciliation God offers the individual forgiveness and freedom from guilt. The apprehensive imagination of future uncertainties is also negated. The individual has the assurance that no matter what transpires, God's attitude towards him as a person is always one without condemnation. This does not mean that God condones sin or opens the door to cheap grace, but it does mean that the individual can be assured no matter what the depth of his sin that God is still willing to forgive him because of the historical nature of the great act of reconciliation. And finally, the paralyzing web of boredom in present experience is broken as the individuai is liberated to respond to existing relationships. Walls of alienation are broken down and avenues of comunication and communion are opened up. God and other people are no longer perceived as enemies, 
and all the possibilities of exploring and experiencing the depth and richness of those relationships lies before the individual. In Oden's words:

The Christian community does not merely teach the "idea" that we are being valued despite our value negatives. It celebrates and proclaims a particular historical "event" in which we are once and for unconditionally valued amid our value negations.

\section{The Church in Community}

Gavin Reid has shown in a powerful way how the forces and structures of men's relationships with each other have quickly changed from a community basis in medieval times to one of complete isolation of the individual today, a process which began with the effects of the industrial revolution and climaxed with television. He maintains that genuine communication does not occur in 80 percent of such industrial countries as Britain and the United states. ${ }^{2}$

This lack of community exists not only in society but is also "critically lacking in much of the institutional church today." 3 True Christian fellowship, what the Greek New Testament calls koinonia, is the Spirit's gift to the church, and much of the impotence, rigidity, and seeming irrelevance of the modern church can be traced to its absence. This is manifested in the growing popularity of house and store front churches today.

\section{Ioden, p. 90 .}

${ }^{2} G$. Reid, The Gagging of God (London: Hodder \& Stoughton, 1971), p. 22.

3H. A. Snyder, The Problem of Wineskins (Downers Grove: Intervarsity Press, 1975), P. 89. 
Biblical koinonia is very broad in its implications and sphere of application. It touches the alienation experienced in the church between different races, between different cultures, between the haves and the have nots, between men and women, between husbands and wives, between parents and children, between the young and the old, between laity and clergy, institution and people, or just between brethren over some local and personal conflict. All these estrangements have the potential of reconciliation as God's one great act of reconciliation is brought to bear on interpersonal relationships. This is indicated in the following scriptural passages bearing on the theme of reconciliation:

From now on then we regard no one from a human point of view $(2 \operatorname{cor} 5: 16)$

Gave us the ministry of reconciliation (2 Cor $5: 18$ )

- . the wife should not separate from her husband [but if she does, let her remain single or else be reconciled to her husband] ( 1 Cor $7: 10,11$ )

So if you are offering your gift at the altar, and there remember that youx brother has something against you, leave your gift before the altar and go; first be reconciled to your brother, and them come and offer your gift (Matt 5:23, 24)

Therefore remember that at one time you Gentiles in the flesh, called the uncircumcision by what is called the circumcision, which is made in the flesh by hands-remember that you were at that time separated from Christ, alienated from the commonwealth of Israel, and strangers to the covenants of promise, having no hope and without God in the world. But now in Christ Jesus you who once were far off have been brought near in the blood of Christ. For he is our peace, who has made us both one, and has broken down the dividing wall of hostility, by abolishing in his flesh the law of commandments and ordinances, that he might create in himself one new man in place of the two, so making peace, and might reconcile us both to God in one body through the cross, thereby bringing the hostility to an end. And he came and preached peace to you who were afar off and peace to those who were near; for through him we both have access in one Spirit to the Father. So then you are no longer 
strangers and sojourners, but you are fellow citizens with the saints and members of the household of God (Eph 2:11-19)

God's act of reconciliation does something to the way we regard other people. It enables us to see the breadth of the "all" who died when the "one" died. We realize that God does not condemn the other person any more than He condemns us. He offers to them the same unconditional acceptance that He offers us. When we look at other people through the eyes of the cross, we see them as part of the new creation and relate to them accordingly. "No human being, then, can ever be approached as anyone other than a person whose rightful place is within the divine relationship." ${ }^{1}$ Barriers of alienation are broken down and we can offer them the same unconditional acceptance that God offers them. Our old way of regarding people from a human point of view, based on estimates formed "upon purely human and especially self regarding considerations" ${ }^{2}$ does not apply anymore. The tendency to judge people's lives by those elements that reveal the unfortunate fact that they are still part of the old creation (this present age rather than the age to come) no longer prevails. We look at others now through new spectacles; they, like us, have been reconciled to God. "Here then is part of what koinonia means. It is basically a common participation in the life of God in Christ, and that in turn implies a common participation in the whole sweep of his mission. ${ }^{3}$

IK. Griffen, "The Church as a Therapeutic Community," in Theological Foundations for Ministry, p. 735.

2 Barrett, Corinthians, p. 170.

${ }^{3}$ B. Milne, We Belong Together (Downers Grove: Intervarsity Press, 1978), P. 30 . 
God has not kept to himself the work of making His act of reconciliation known to men. He has called us to a ministry of reconciliation where in all possible cases and all possible ways we are to effect reconciliation between parties that are estranged, irrespective of whether we are personally involved or not. It is an echo of Jesus' words in the Sermon on the Mount where He said: "Blessed are the peacemakers for they shall be called sons of God" (Matt 5:9).

The peace which Christ brings does not necessarily wipe out our differences or conflicts with one another. It does not mistake unity for uniformity. It crosses the barriers of human differences without nullifying the differences. Instead of seeing people through the cowboy morality of good guy or bad guy, Anne Ulanov says the ministry of reconciliation "dares to see every person as special," and no matter what their situation "every person is seen as worthy of serious hope, help, support, and reverence." I

In Thomas Oden's schema of awareness, the ministry of reconciliation is depicted as love overcoming alienation in interpersonal (I-you) relationships manifested in such things as overdependence, depersonalization, withdrawal, and aggression. These are replaced with a covenant concern and care for others, a genuine love. ${ }^{2}$ Milne points out that this love cannot be mustered up by any amount of human exhortation, no matter how biblical or passionately it may be presented. Nor is it achieved by any type of "fellowship structures, however imaginatively organized." 3 It is

$$
{ }^{1} \text { ulanov, p. } 47 . \quad \text { 2oden, pp. 251-261. 3Milne, p. } 39 .
$$


only awakened and summoned to constrain man's relationship with his neighbors when the great act of God's reconciliation is perceived in all its fulness and implications.

Such a ministry of reconciliation applies specifically to the following different areas of alienation and interpersonal conflict in a local parish.

\section{Church Conflict}

In the Sermon on the Mount (Matt 5:23, 24) Christ counsels the Christian to take the initiative before worshipping God and effect reconciliation in the event of an existing interpersonal conflict. This seems on the surface to reverse the theological basis of reconciliation. But such is not really the case. The worshipper is already in a covenant relationship with God, and any failure to deal with and put right any estrangement that may arise shows a failure to understand the nature and implications of God's act of reconciliation.

Seeing the need to achieve reconciliation and being able to facilitate it in practice may be two different issues. As Dennis Kinlaw points out, "Christians may have very powerful theological imperatives to establish community, but they may be totally lacking in behavioral skills to enact such a community."l The skills of conflict resolution are developing rapidly today whether it be in

${ }^{1}$ D. C. Kinlaw, "Sharing the Ministry of Interpersonal Help," instruction material for Commonwealth Training Associates, Norfolk, Va., received when taking the class M-608 Pastor as Skilled Helper, in the Winter Quarter 1979-80 at the McCormick Theological Seminary. 
the area of peer counselling ${ }^{I}$ or professional consultants, ${ }^{2}$ but for the use of these skills to be really effective in a church it is imperative that the parameters be set, not by humanistic behavioral skills but, rather, by the theological undergirding and motivation of God's act of reconciliation.

Kinlaw's program of developing helping skills in the area of solving church discord lends itself beautifully to building on this theological undergirding. This is because the characteristics of his helping process are:

(a) a disposition by the helper to understand with the helpee

(b) a relationship of "respect" (a technical term placing value on people and facilitating behaviors)

(c) a problem-centered rather than person-centered approach ${ }^{3}$ All these characteristics reflect a complete unconditional acceptance of people, even in conflict.

The process itself is described as a "Generic Model for Interpersonal Help" 4 and has four stages:

(a) Moving Together - in which trust and rapport are gained

(b) Moving Down - in which full awareness of the problem is sought through searching and appropriate disclosure.

$I_{\text {For good approaches in this field see: P. M. Miller, Peer }}$ Counselling in the Church (Scottdale: Herald, 1978); D. C. Kinlaw, Helping Skills for Developing Human Resources (Norfolk: Commonwealth Training Associates, 1978).

${ }^{2}$. Leas and P. Kittlaus, Church Fights (Philadelphia: Westminster Press, 1973).

3 Kinlaw, Heloing Skills for Developing Human Resources, p. 3. ${ }^{4}$ Ibid., p. 1. 
(c) Moving Out

(d) Moving Apart
- in which definitions of the problem are sought and owned, and action plans formulated for change

- in which resolution is accomplished with confidence and anticipation

\section{Marriage Conflict}

First Corinthians 7 deals extensively with various marriage problems and it becomes evident as Paul's counsel is studied that every effort should be made to effect a reconciliation (vss. 10, 11) in the event of estrangement and alienation. In Matt 5:27-32; 19: 3-9 and Mark 10:2-12 Jesus addresses the question of divorce and adultery. By comparing Acts 15 with Leviticus 17 and 18 Boltensweiler' argues forcibly that Jesus' use of the word "porneia" is a technical term for incestuous marriages common among Gentiles of the Middle East. Jesus speaks as the new Moses and takes his listeners back beyond rabbinic and Mosaic tradition to God's original purpose for marriage as he himself had instituted it in Eden. Commenting on the passage in Mark 10 Stauffer says that the fundamental unity of marriage partners "is posited and actualized in accordance with creation." 2 He emphasizes that this means "quite clearly and unambiguously" that dissolution of marriage may be conceded at a pinch, but that there must be no contracting of a new marriage.

Jesus does not open the door to divorce through

$I_{\text {Heinrich Boltensweiler, Die Ehe in Neuen Testament }}$ (Zurich/Stuttgart: Zwingli Verlag, 1967), pp. 92-119.

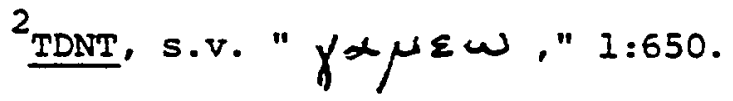


unfaithfulness or sexual deviances of any other kind except an incestuous marriage, and even that, Boltensweiler maintains, was more an annullment than a divorce. Jesus is asserting the life-long nature of the marriage covenant that partners ought to recognize. This is a reflection of the everlasting covenant God has made with His people and is meant to be a tableau that no matter how many times unfaithfulness has occurred, God is willing to renegotiate and reestablish the covenant--make it new. Looking at. these same texts from a slightly different viewpoint, Barth nevertheless comes to the same conclusion. "Divorce is quite impermissible. . . The reservation 'except for unchastity' or something similar is found in some of these texts, but it seems to be a later addition to soften the original and unqualified direction." 1

In practical encounters with adultery (John $4: 16-19 ; 8: 1-11$ ), however, Jesus showed the depth of grace in meeting people where they were in their cultural and personal morality by offering them unconditional acceptance. He relied on the power of their love response and the outworking of the cross in its applied sense to control ethical issues and heal marriage tensions.

It becomes clear that no matter how deep the rift in a marriage relationship may be, even if there has been repeated adultery, that reconciliation is possible and should be sought. Only if one partner refuses to bring the principles and implications of God's act of reconciliation into the relationship and physical and psycho-emotional life is threatened, is separation permissable. p. 31 .

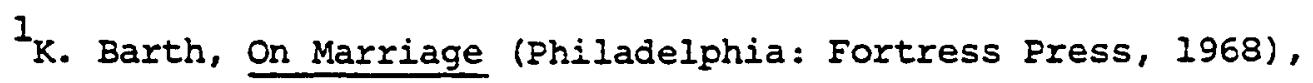


But even then, the Christian party should not initiate divorce. When both parties, however, are willing to let God's act of reconciliation work itself out in their marriage, a basis has been formed to offer each other total unconditional acceptance no matter how guilty and faulty each party has been.

Christ's pattern of accepting lost mankind in his spiritual adultery becomes the motivating, constraining well-spring of estranged husbands and wives. In actual practice, as $c$. W. Stewart recognizes, ' it may not always be possible because of the highly charged emotive issues and deeply rooted causes of hostility to start with a pure theological basis to effect reconciliation. In such cases it is still possible for a counsellor to lead such a couple through steps that facilitate the same dynamics in their experience that are embodied in God's act of reconciliation. Just as God faces the sin problem squarely and deals with the cause of his hostility to mankind and wants mankind to face those causes too, "the primary function of the early session with the husband and the wife is to allow the expression of deep seated resentments and hostilities." 2

Here the counsellor can help the couple immensely by modelling to them complete acceptance of them both, without arguing as to the rightness or wrongness of the provocation. After allowing a cooling-off period and facilitating further realistic

${ }^{1}$ c. $w$. Stewart, The Minister as a Marriage Counsellor (Nashville: Abingdon, 1970), P. 111.

2 Ibid., p. 107. 
confrontation, Stewart maintains the basis of reconciliation has been reached when "each accepts the other as he is, with both his assets and his liabilities, rather than operating in terms of a fantasied picture of the other." 1 Gibson winter writes that a couple must actually decide to enter a covenant of intimacy. ${ }^{2}$ Having done this, viz., laid the basis of reconciliation, they proceed to become reconciled to each other by harmonizing their desires and working out their fears. "So each issue-in laws, personal appearance, division of work responsibility, respecting privacy, the use of alcohol-comes up with some possibility of a working agreement to be arranged." ${ }^{3}$

It is very interesting to notice that at this stage the "courtship period begins again quite naturally. When reconciliation actually starts operating between two people, each is spontaneously motivated to 'win' the other again." 4 How perfectly this echoes Paul's sentiments in 2 Cor 5:14 when he says the love of Christ controls us when we become convinced that in the death of one for all, then all have died. "In all such cases the participation in the gospel is not on the level of explanation but of meaning, " 5 what P. F. Wilczak called "meta communication" of reconciliation.

${ }^{1}$ Ibid., p. 109.

${ }^{2}$ G. Winter, Love and Conflict (Garden City, N.Y.: Doubleday \& Co., 1958), p. 111.

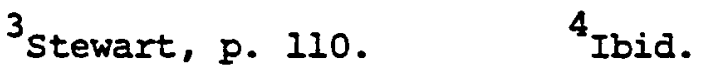

5. F. Wilczak, "The Pastoral Care of Families: A Ministry of Reconciliation," Encounter 39 (Spring 78): 180 . 
The ability to establish, nurture, and sustain in intimate human relationship, and the ability to commune vitally with nature, the universe and God, are vitally connected. Furthermore, each of these kinds of relatedness profoundly influences the other. He who loves his spouse, whom he has seen, is better able to love God whom he has not seen, and vice versa.

\section{Parent-Child Conflict}

As well as husband-wife relationships, God's act of reconciliation provides the basis for resolving alienation between parents and children. Merton strommen has documented valuable research revealing the extent and depth of alienation experienced by youth. The unvoiced cry of self-hatred "haunts the lives of one young person in five. It rises out of feelings of worthlessness, self criticism and loneliness. . . When (self-esteem) is lacking alienating and self destructive types of behavior appear." 2 The second of Strommen's five cries of youth (that of psychological orphans) rises from "young people who desperately need the stability, support asd love of a home they don't have to deserve. The cry of these young people is: 'I need to be part of a family where we love and accept and care about each other'. " 3

Roger Dudley has spent much time studying the reasons why teenagers leave the church and concludes that poor relationships with parents or teachers, where the teenager does not feel accepted,

$1_{H}$. J. Clinebell and C. H. Clinebell, The Intimate Marriage (New York: Harper \& Row, 1954), p. 180.

2M. P. Strommen, Five Cries of Youth (New York: Harper \& Row, 1974), Pp. 12, 13 .

3 Ibid., p. 34. 
is the biggest factor likely to alienate youth from religion. ${ }^{1}$ He strongly recommends parents adopt Carl Rogers' principle of "unconditional positive regard" ${ }^{2}$ which is a warm acceptance of, and a prizing of, the other person as a separate individual. Parents should place no conditions on love for their children and seek to convey that although some of their actions may cause deep pain and not meet with parental approval, yet nothing they may do or say could cause love to cease. In so doing parents reflect God's reconciliation with mankind. The realization of this unconditional positive regard is the only thing, Dudley says, that will melt people's hearts and lead them to surrender to Him.

There have been many manuals published on child training, but one that possibly comes the closest to basing its principles on God's act of reconciliation is Ross Campbell's How To Really Love Your child. ${ }^{3}$ Campbell recommends a superabundance of eye contact, physical contact, and focussed attention as a means of loving children unconditionally. He warns against the poor relationships between parents and their child resulting from loving with possessiveness, seductiveness, vicariousness, role reversal, and punishment without a firm foundation of loving training. ${ }^{4}$

$I_{R}$. C. Dudley, Why Teenagers Reject Religion (Washington, D.C. : Review \& Herald, 1978), p. 120.

I Ibid., p. 125.

3 Ross Campbell, How To Really Love Your Child (Wheaton: Victor Books, 1977).

4 Ibid., pp. 101, 102. 
Generation Conflict

One final area of family relations in which God's act of reconciliation can heal alienation is the relationship between the family and the older person. Too often a situation described by Robert Butler as "ageism" arises--a process of " . . systematic stereotyping of and discrimination against people because they are old, just as racism and sexism accomplishes this with skin color and gender." 1 young people come to think the aged as senile, rigid in thought and manner, old fashioned in morality and skills. Thus they are categorized as being different and even less than human.

Even though an older person may have had a sound religious experience in his earlier years, this may readily be clouded over by the unique stresses that face him. Gray and Moberg ${ }^{2}$ have succinctly sumarized the emotional, mental, and spiritual factors that old people have to grapple with which produce a loss of self-worth and facilitate a sense of alienation from their own personal perspective. Without minimizing the sociological and behavioral dynamics involved in relating to the aged, the offering of complete unconditional acceptance to them in a way that genuinely affirms and supports their self-worth provides the only basis to achieve p. 12 .

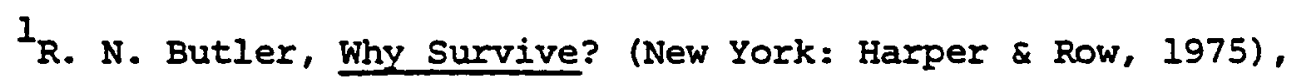

2R. M. Gray and D. O. Moberg, The Church and the Older Person (Grand Rapids: Eerdmans, 1977), pp. 42-49. See also Elizabeth B. Hurlock, Developmental Psychology (New York: McGraw Hill, 1980), PP. 389-452. 
reconciliation. Acceptance and affection are two of the three "A"s (along with achievement) that Hurlock says are necessary for happiness in the experience of old people.

Racial Conflict

The church has long known, in theory at least, that "There is neither Jew nor Greek, there is neither slave nor free.. . for you are all one in Christ Jesus" (Gal 3:28). In actual fact, racial tensions still have a tenacious hold on the church today. William Rader notices that the beginnings of the church "took place amidst forces of group hostility similar to those of today."I He goes ahead to make an historical study of Eph 2:11-19 to see how theologians down through the Christian era have applied this great reconciliation passage to contemporary racial conflict and concludes that the church should show visible as well as invisible unity in this area. It is obvious to him that implications of Christ's reconciliation of Jew and Gentile through his life, death, and resurrection has had little effect on the church and should receive more attention. C. H. Dodd is another who treats this theme. In his Christianity and the Reconciliation of the Nations he states: "We may fairly treat it (Eph $2: 11-15$ ) as a model of the progress of reconciliation between nations" ${ }^{2}$ as it illustrates how longstanding and deep rooted enmity may be effectively overcome.

Close examination of this passage in Ephesians reveals that

$1_{W}$. Rader, The Church and Racial Hostility (Tubingen: J. C. R. Mohr, 1975), p. 254 .

${ }^{2}$ C. H. Dodd, Christianity and the Reconciliation of the Nations (London: S. C. M. Press, 1952), P. 25. 
it is God's great act of reconciliation that lies at the basis of this healing of hostility and hatred. It is "the blood of Christ" that has brought the Gentiles "near" to God. Similarly, the blood of Christ offers "peace" to those who are already "near" (used in the sense of privilege). It is their common "nearness" and their common "peace" with God that radically alters their estimation of attitudes towards each other. Instead of two different groups there is now only one "new" man in Christ. Such a work of unification of two opposing camps on this theological basis "surpasses anything that might be called merely peaceable or conciliating or even loving." 1 Furthermore, "Gentiles do not simply rise to the status of Jews, but become something new and greater." ${ }^{2}$ F. F. Bruce points out that "Paul uses three figures to express the unity of Jewish and Gentile believers in the new fellowship which Christ has created: (i) a city; (ii) a family; (iii) a building, " ${ }^{3}$ and each of them springs in an eschatological sense from God's great act of reconciliation. They convey the completeness, intimacy, and unconditional acceptance offered to all that become reconciled to God. This passage becomes especially relevant to the church when theological positions are formed and defended largely because of cultural heritage. Those Christians from nations having a Calvinistic Reformed background often have difficulty relating to

$I_{M}$. Zerwich, The Epistle to the Ephesians (New York: Herder \& Herder, 1969), p. 66 .

${ }^{2}$ F. Faulkes, The Epistle of Paul to the Ephesians (Grand Rapids: Wim. B. Eerdmans, 1963), P. 83.

3F. F. Bruce, The Epistle to the Ephesians (Iondon: Pickering \& Inglis, 1961), p. 56. 
Christians who look at theology through the spectacles of Arminianism. It is then, even when theological differences lie at the basis of alienation, that God's act of reconciliation needs to undergird their relations. Dietrich Bonhoeffer pointed out that no Christian has the right to endeavor to regulate, coerce, or dominate any person with love. Each must maintain his independence, to be loved as an individual for whom Christ became man, died, and rose again in order to bring forgiveness of sins and eternal life. "Because Christ has long since acted decisively for my brother, before I could begin to act. I must leave him his freedom to be Christ's; I must meet him only as the person that he already is in Christ's eyes." I

In drawing to a conclusion this section on the working out of koinonia in different areas of life, we need to point out that achieving real and effective fellowship among Christians is no easy matter. Tensions, strains, and division are distressingly common experiences even where there is a basic concord of outlook. And yet as Bruce Milne points out, the New Testament "assures us that these Christian people for all their apparent inability to live together in harmony really do have a basic unity." ${ }^{2}$ Their call to live together in love and harmony in Christ is a call to become in practice and in outward life what they already are by virtue of their share in Christ's victory. p. 35 .

1D. Bonhoeffer, Life Together (New York: Harper \& Row, 1954), 2Milne, pp. 32,33 . 
Koinonia is not something to struggle after in order to attain. It is rather a call to realize something that already exists because of Christ's reconciling act. This is the consistent biblical teaching on this matter, that fellowship with one another issues from an exposition on the basis of that fellowship: our common union with Christ in death and resurrection. ${ }^{l}$ In Christ sin and all its powers have been overcome, including that which separates us from our neighbor.

\section{The Church in Mission}

This alienation of man from God, himself, and his neighbors, which has intensified with the passage of time, has made the church's traditional modes of evangelism increasingly difficult and fruitless. This is reflected in both Seventh-day Adventist and other evangelical journals where an increasing mood of analysis and reassessment is evident. These churches, especially in the first and second worlds, are grappling with evangelistic impotence, declining growth rates, and a deteriorating quality of intraexperience.

The report of the Ministerial Association Advisory held between 30 April and 2 May 1979 epitomises this mood among Adventists where foremost among the specific aims and objectives was the desire to "clarify the mission and purpose of the church." 2 The introduction to the Lausanne Covenant drawn up at the International

${ }^{1}$ C.f., Rom 6ff. and $12: 3-13 ;$ Gal $2: 20$ and $6: 1-5 ;$ Eph $2: 5,6$ and $4: 7 f f . ; \operatorname{Col} 2: 12 f ., 3: 1 f$, and $3: 8-17$.

2 "Ministerial Association Advisory Report," Ministry, October 1979, p. 20. 
Congress on World Evangelism in 1974 expressed the same mood among the evangelical churches when it said: "We are... moved to penitence by our failures and challenged by the unfinished task of evangelism." 1 More recently this mood was deepened as the evangelical churches entered the 1980s and considered their condition and task. After describing the advances of the church in the 70 s and the potential for world impart, Carl Henry observes that "all this is far from being an effective evangelical penetration of public mood and conscience." 2 The church, not the world, has confidence that God and not earthly Caesars govern the daily fortunes of history.

These different conditions, all suffering from the same pervasive malaise, make a theology of reconciliation especially relevant and necessary in all areas of ministry and evangelism. Biblically, this is revealed to us in the following passages: - Christ. . gave us the ministry of reconciliacion (2 Cor $5: 18$

So we are ambassadors for Christ, God making his appeal through us. We beseech you on behalf of Christ, be reconciled to God (2 Cor $5: 20)$

The great bulk of literature written today about the ministry of reconciliation deals with the church's role in removing alienation in the areas of political, racial, economic, sociological, cultural, ecological, and sexual estrangements and hostilities in a purely

IJ. D. Douglas, ed., Let the Earth Hear His Voice (Minneapolis: World Wide Publications, 1975), p. 3.

${ }^{2}$ C. F. Henry, "Evangelicals: Out of the Closet but Going Nowhere," Christianity Today, January 1980, Pp. 18-20. 
humanitarian sense. ${ }^{1}$ And all this is apart from the framework of first seeking to effect the individual's reconciliation with God. While not denying the idealistic comnendability of most of these humanitarian projects, a Christian is denying the theological undergirding of reconciliation if he pursues it in a merely secular way. He is doomed to failure in the absolute sense.

The Ministry of Reconciliation in Proclamation

A study of contemporary theology has shown that reconciliation is often thought of in merely humanistic terms. But " . . granted that such terms are certainly relevant to our understanding of the distinctively Christian meaning of them, we must guard against making them decisive." ${ }^{2}$ From an exegetical point of view "the ministry of reconciliation" is not primarily between estranged men, although that will follow when men are truly reconciled to God, but comprises a proclamation by men to men about God's act of reconciliation, followed by carnest efforts and appeals to "persuade" and "beseech" men to accept the work provided for them. This objective content of the proclamation cannot he too strongly emphasized. God does not call us in the first place to an inner experience, although that too will follow. He is summoning man to accept God's act of reconciliation done for him, outside of him, in Christ's death on the cross. The ministry of reconciliation is

${ }^{I}$ See for example D. T. Rowlingson, "The Minister's Role as Reconciler," Religion in Life 35 (1966): 57-66.

2D. G. Miller, "Toward a Theology of Evangelism," Christianity Today, May 1980 , p. 6 . 
"the office and duty of announcing this reconciliation." 1 The word K $\alpha T \alpha \lambda \lambda \alpha \gamma \eta T \varepsilon$ is passive and invites the hearer to "embrace the offer of reconciliation. - . All we have to do is not to refuse the offered love of God." 2 This is not to imply a lack of concern with the results. We cannot fail to note "the strong note of urgency and compassion in the Apostle's language." ${ }^{3}$ Yet despite this, the main thrust of the ministry of reconciliation still remains the proclamation of God's act.

Barrett emphasizes that in a very real sense this preaching about God's act of reconciliation belongs to the event of salvation itself. In such preaching "God's own word to man is encountered." 4 Preaching must never deteriorate into a narrative account of a past event that once happened. It is not a message "about" reconciliation. Neither must it strive to exhort or achieve reconciliation on philosophical grounds. In proclaiming God's act of reconciliation "the reality and power of the event of reconciliation are brought near." 5 In saying this it is not necessary to go to the extreme of Bultmann in limiting reconciliation to an encounter in the "Now" severed from a significant fact of world history in the past. 6 And yet having said all this on the ministry of reconciliation as proclamation, it must still be made clear that this

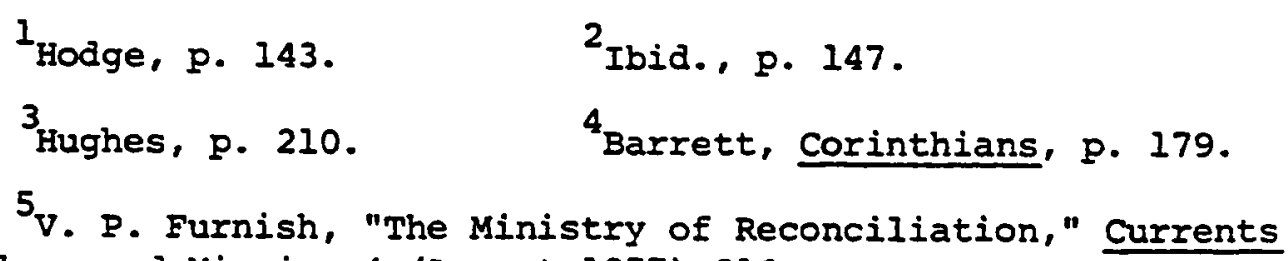
in Theology and Mission 4 (August 1977): 216 .

6R. Bultmann, Theology of the New Testament (New York: Charles Scribner's Sons, 1951), 1:302. 
ministry is larger than just helping people get to heaven when they die; it is rather to the whole man in his total environment.

A genuine theology of evangelism is all inclusive, dealing with the total human situation. It encompasses the whole range of man's reconciliation to God and to his fellow man, and concerns, itself with the unshackling of men's bodies, minds and spirits.

\section{The Ministry of Reconciliation}

in Health Programs

The Seventh-day Adventist Church has a unique opportunity with its many Better Living programs offered to the public to turn these into a ministry of reconciliation. The many stop Smoking Clinics, nutrition and cooking schools, Stress Management classes and risk tests in the area of coronary and cardiac diseases could readily be used for more than a public relations venture or an interestgetting bridge to spiritual and doctrinal concerns. There is a difference between a community service and a ministry of reconciliation. The former, no matter how altruistic, leaves the person a bit healthier but still part of the old creation, still unreconciled to God.

The many Total Health clinics springing up in the United States where doctors, psychologists, and ministers work in cooperation with all aspects of a patient's needs is getting closer to what is involved in reconciliation. If health is set in the framework of experiencing the life of the new creation, in the here and now, then it forms a legitimate part of the ministry of reconciliation. Instead of becoming merely good secular counsel (albeit in a

\footnotetext{
${ }^{1}$ D. G. Miller, "Toward a Theology of Evangelism," p. 5.
} 
spiritual atmosphere) it then becomes a tasting of the firstfruits of the Kingdom of God already ushered in at the time of God's great act of reconciliation. It becomes an anticipation of life in the new creation after the consumation.

As such, the practical presentation of these programs to the public needs to have a different theological base and different theological goal. The church must use man's quest for health to open his eyes to the depth and extent of his alienation from God, for this alienation is the real essence of his unhealth. To instruct people to keep the laws of health as we often do in these programs is actually an antithesis of the ministry of reconciliation. To do so only increases man's alienation from himself and from God because of the dynamics of guilt involved in inherent failure in such an approach. It is only when Jesus is portrayed as the One who is truly human; rightly related to God, man, and the world; wholesome, holy, and healthy; and in harmony with God's laws that health becomes part of the ministry of reconciliation.

We may have all this by faith. We say faith because perfect health, wholeness, absolute harmony with God's perfect law, is not in us but in Christ. It is like a fabulous inheritance given to a child. . . I He can even draw upon the inheritance
for his present needs.

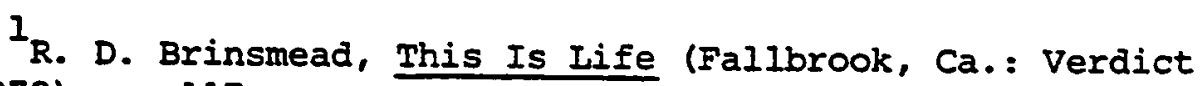
Pub., 1978), p. 117
} 
The Ministry of Reconciliation

in Counselling

In his Kerygma and Counselling ${ }^{l}$ Thomas Dden has endeavored to form a model of secular counselling based on the analogy of God's self-disclosure to mankind. This provides us with a stepping stone to turning counselling into a ministry of reconciliation in the fullest theological sense we have been considering. Corresponding to God's revelation of His incarnation, divine congruence, forgiveness, grace, and Divine love, ${ }^{2}$ the therapist extends to the individual being counselled an empathetic understanding, a therapeutic congruence, an acceptance, a permissiveness, and an unconditional positive regard, respectively. These attitudes are modelled on God's attitude towards alienated mankind. ${ }^{3}$ This approach leads to a response in the individual of increased self-understanding, increased self-identity, increased self-acceptance, increased selfdirection, and increased love for others, respectively. It is an effective growth on his part toward authenticity and as such an experience in the secular realm similar to the spiritual dynamics of entering into the reality of all which God's act of reconciliation provided.

All this is very helpful to a Christian therapist counselling someone who is either too confused to hear any theological principles in dealing with his problems or he is not inclined to enter

\footnotetext{
${ }^{1}$ (San Francisco: Harper \& Row, 1978).

2 Ibid. . p. 49. $\quad 3$ See also x. Griffen, p. 735.
} 
into therapy on a spiritual basis. The therapist's behavior, attitude, and techniques all model to the individual God's dealings with him and allow him to experience vicariously in his therapist the spirit of God's act of reconciliation. To remain there, however, is still to fall short of the ministry of reconciliation. If the individual remains part of the old creation and does not ultimately seek reconciliation with himself or with others in the framework of God's act of reconciliation, he is still doomed to ultimate alienation even if the dynamics of his self-understanding are somewhat improved through the skills of behavioral science. Oden overlooks this when he equates the experience of therapy modelled on God's reconciliation with reconciliation itself. All kerygma does in his understanding is witness overtly to the hidden source of healing that has already taken place through God's silent working in therapy. Kerygma involves the explicit clarification of the meaning of events that transpire in therapy. ${ }^{I}$

The great fallacy of this notion is that even an atheistic therapist who has not become reconciled to God can, by modelling his therapy in a secular way on God's act of reconciliation with man, effect reconciliation in his patient. Man in the old creation can still reflect the image of God, but this does not mean he is reconciled to God. Ultimately the therapist must lead his patient to see that God was in Christ reconciling the world unto Himself and lead him to accept and experience his reconciliation, or else his work is not a ministry of reconciliation at all but an imitation

Ioden, Kerygma, p. 152. 
of it. A human incarnation of God's ministry can never take the place of what was involved in God's incarnation in human ministry. The former must lead to the latter or else it is mere humanism and tragically incomplete. Of the Christian counsellor it must be said :

His constant aim will be to unmask the conflict between men and God, and open the way to reconciliation. Psychological insight will help him to reveal men to themselves, to disentangle the confusions, and to uncover the insincerities with which men screen themselves against the truth. It will help him to lay bare the hidden roots of fear and resentment that often run back into the forgotten past. But final healing and the integration of the personality can come only from reconciliation to God.

The Ministry of Reconciliation

in Ecology

". . and through him to reconcile to himself all things, whether on earth or in heaven, making peace by the blood of his cross" Col 1:20. Paul indicates in this passage of scripture that reconciliation has much wider dimensions than the spiritual factors related to man's salvation. It encompasses the whole of the natural world and even the universe itself. The "blood of his cross" has affected reconciliation in the universe already, but it still waits for that reconciliation to be openly disclosed.

For the creation waits with eager longing for the revealing of the sons of God; for the creation was subjected to futility, not of its own will but by the will of him who subjected it in hope; because the creation itself will be set free from its bondage to decay and obtain the glorious liberty of the children of God. We know that the whole creation has been groaning in travail together until now; and not only the creation, but we ourselves, who have the first fruits of the spirit, groan

\footnotetext{
IF. V. Filson, The Interpreter's Bible, 10:343.
} 
inwardly as we wait for adoption as sons, the redemption of our bodies (Rom 8:19-23).

The consumation spoken of here is a fulfillment of the covenant made with Noah recorded in Gen 9:13, that embodied not only mankind but the earth and all creation. In the words of T. F. Torrance: ". God declined to allow His creation to lapse from Him into degeneration and corruption." 1 In the incarnation God began the first steps of entering into the disorderly depths of our creaturely existence in order to ultimately integrate all things visible and invisible in the universe once again. Commenting on the term "all things" in 2 Cor 5:18 Barrett says: "Héring and Barth (C.D. 111.i. 3.) take "all things" to refer to the universe, creation as a whole, and the proposition that it is the Creator who reconciles is theologically correct." ${ }^{2}$ John Murray supports this when he says: "Sin cannot be isolated in its effects; it is the contradiction of God and the wrath it must evoke has its cosmic repercussions." 3 The Fall not only separated man from God but also caused other deep separations, including man from nature, and even nature from itself. God's act of reconciliation provided ultimate healing for all alienations. Talking about the rift in nature caused by sin Francis Schaeffer expresses the thought that Christians are not to put off that healing process until that one day when Christ comes

1T. F. Torrance, "The Church in the New Era of Change," in Theological Foundations for Ministry, p. 767.

2 Barrett, Corinthians, p. 175.

${ }^{3} \mathrm{~J}$. Murray, "The Reconciliation," Westminster Theological Eournal 29 (November 1966) : 3 . 
back, but on the basis of the work of Christ "substantial healing can be a reality here and now." ${ }^{1}$ This thought captures the essence of a Christian's ministry of reconciliation in the area of ecology. By becoming conscious of the effects of pollution in a theological framework, and seeing it as the end result of alienation in nature, he can radically reorient his behavior and incorporate nature into his sphere of making reconciliation a realized event in the present as much as possible. In Oden's schema ${ }^{2}$ the sub-personal (I-it) relationship with the world of non-human creation and natural environment changes from one of abuse and defilement to one of reclamation amid desecration.

\section{The Ministry of Reconciliation} in Society

Ignacio Ellacuria is perhaps one of the most radical theologians in this area of social reconciliation. He reasons that the church

must foster the full integral salvation of man and that entails a political dimension. . . Like christ, the church is here to take away the sin of the world . . . the objective shackles of hunger, sickness, ignorance, and helplessness, and from the artifically created shackles of a consumer society.

There is some truth in what Ellacuria says. The betterment of society in history has always been the result of individual christians using their influence in political ways to establish more

IF. A. Schaeffer, Pollution and the Death of Man (Wheaton: Tyndale, 1970), p. 67.

2 Oden, Structures, pp. 262-270.

3. Ellacuria, "Liberation: Mission and Charism," in Theological Foundations for Ministry, pp. 612, 616, 621 . 
humane conditions in line with Christ's estimate of the dignity of man. But in the real sense of biblical reconciliation Ellacuria's approach confuses the work of God with the work of man and turns out to be an effectual negation of all that reconciliation involves. Social reconciliation is not an imitation of, or re-enactment of, God's act of reconciliation on a secular level. To say that is to make the same mistake Oden made in establishing a secular counselling methodology on the model of reconciliation and identify it as effectually the same thing.

The kingdom of God does not come by secular politics. The church has a moral responsibility to act as conscience for society and speak out against flagrant injustices and immoral forces. But it can go no further. If proclamation of the great act of God's reconciliation cannot change the springs of man's being, all the political machinery in the world cannot usher in the new creation. The church can best perform its ministry of reconciliation in society by acting out the new creation which has been fulfilled in the life of Christ; by feeding the hungry, clothing the naked, comforting those that mourn, crossing racial barriers, and becoming poor for the sake of those in need. Effectually this is giving society a preliminary disclosure of the creation reconciled once and for all by the blood of Christ. Building on the statement in Heb 13:12, 13, that Christ suffered outside Jerusalem, J. Moltman emphasizes that "we cannot confine reconciliation to the ghetto of our hearts." 1 The christian is to go forth outside the camp,

IJ. Moltmann, "God Reconciles and Makes Free," in The Reformed and Presbyterian World 31 (Sept \& Dec 1970):112. 
bearing abuse for him. Just as God's act of reconciliation was accomplished not in a sanctuary but in the lowest point of the world, so the Christian cannot celebrate that reconciliation isolated from the world's suffering.

In summarizing this chapter it can be said that God's act of reconciliation in Christ is not without very real implications in the realm of our human alienations. It provides the basis for effective therapy to the individual grappling with the psychological, emotional, and spiritual problems in our modern existential society. It offers a foundation for the healing of interpersonal rifts in the church, in the family and between different races. It spells out how the church can do its work of mission through proclamation, health programs, counselling, and ecological sensitivity.

In the next chapter the ways in which these principles were enacted in a local parish setting will be documented. 
CHAPTER IV

IN PRACTICE

Having considered both the theology involved in God's act of reconciliation and the implications flowing from it in the area of human experience, this chapter deals with a practical outworking of the principles involved.

A project was carried out in an actual parish setting, extending over a period of eighteen months from July 1979 to January 1981. The population involved was the Glen Ellyn Seventhday Adventist Church in the Illinois Conference. It is a small, struggling church in the western suburbs of Chicago, and, at the end of the project, had an official membership of thirty-six. Of these only eighteen members attend on a regular basis, but the number is augmented by nine non-members, who attend regularly, and twelve children, who have not been baptized. During the period there were three baptisms, five additions by profession of faith, six transfers in, one death, thirteen transfers out, and none dropped from membership for apostacy.

On 6 August 1979, a special board meeting was held in which a basic outline of the project was shared with church officers. Two diagrams were given to each member present: a pictorial outline of the underlying theology of the project and a tentative schedule for different stages of the project (see appendix A). The whole 
concept was met with an open and sympathetic response, and board members ultimately voted to enter into and cooperate fully with the different aspects of the project.

At the end of the eighteen months both the members and visiting non-members were asked to write out an evaluation of the project by answering in essay style specific questions (see appendix B). It is from these evaluations, together with personal interviews and the writer's own reflection that the overall project was appraised.

The Experience of Individuals

Every possible opportunity was sought to bring all of the members to an understanding of the theology of reconciliation and its implications in their personal lives, their life in the community of faith as a whole, and their witness to the world in a life of mission. This was done in the following ways:

An introductory Sabbath morning sermon was preached in which the general principles of reconciliation and its implications were outlined and a handout about the underlying theology of the project was given to every person. An overhead master was made of this diagram and it was used repeatedly and referred to as a coordinating technique throughout the duration of the whole project.

Full advantage was taken of the Sabbath morning worship hour to preach a series of sermons over the eighteen months that sought to explain and highlight different aspects of reconciliation and its implications (see appendix C). A perusal of these sermon subjects and themes reveals that no attempt was made to rigidiy and 
artificially force every Biblical passage into the mold of reconciliation in a purist sense. The Bible has many themes other than this one. Nevertheless the theme of reconciliation was cognate in some way or other to the themes presented and provided an overall framework that consistently coordinated the messages. On most sabbaths a ten-minute period was reserved at the close of the sermon so members of the congregation could ask questions and reflect on the material given. This time was always used profitably, and at different stages during the project nearly every person participated to a greater or lesser degree. Because of the smallness of the group, great intimacy between the preacher and the congregation developed and, on some occasions, certain members even interrupted the sermon to ask questions. This was never discouraged, though members generally waited until the end of the sermon to express any queries or add any insights.

By the end of August 1979 all members and attendants of the church had been visited in their homes. The purpose of these visits was three-fold: first, it was to provide a low-key way to get to know the parishioners; second, it was to give opportunity to briefly review and clarify the introductory sermon on reconciliation and its implications and to outline the basic direction of the project over the eighteen months to follow; and third, it was to enable the pastor to tentitavely ascertain the parishioner's spiritual condition and his existing grasp of reconciliation as a Biblical concept. It was found that while reconciliation was a term with which everyone was familiar, its meaning to a great majority of the parishioners was limited to the human social level. Neither the theological 
meaning of the term nor its implications on the life of the church were grasped. Because of the small size of the church membership it was also possible over the eighteen months to develop an intimate relationship with the parishioners in their homes. Through various crises and the ordinary flow of parish life, opportunities to visit them often in their homes, at their work, and over the telephone arose. Even when these visits were on a social basis they were all used to gently move the parishioners towards a clearer understanding of and experience in reconciliation and its implications.

On the Sabbath of 16 December 1979, an invitation was extended to the church members from the pulpit and through a letter (see appendix D) to avail themselves of the Sixteen Personality Factor Test and the Motivation Analysis Test. Fourteen people attending church ultimately took the tests and through their influence an additional twelve people who were not church members participated.

During the subsequent interviews the test results were discussed with each individual or couple. Full opportunity was taken of those scores which revealea guilt, anxiety, loneliness, rejection, poor social relationships, a fragile ego, and a lack of selfacceptance to explore with the person his understanding and grasp of reconciliation and all its implications in his relationship to God, himself, and others. This was a very effective medium for allowing the individual's basic approach to life from a theological and practical point of view come into contact with the concept of reconciliation and its implications. Many insights occurred in this process. 
Because of the ongoing nature of the pastoral life of the church, it would be improper to document intimate records of these interviews, but it can be said that they dealt with such areas as prospective marriage, poor marriage relationships, prospective separation and divorce, vocational guidance, singleness, parental conflict, and other unresolved relationships with friends.

The tests together with the sermons and home visitation prompted one parishioner to write two letters (see appendix E) which reflect the critical bearing she understood this theological framework offered to her personal life.

The Experience of the Church in Community

The church was led into an experience of community through a number of mediums. The main and most effective instrument in achieving this was a series of seminars held in the church--and on one occasion in the home of a member--on Sabbath afternoons (see appendix F). The seminars were held every second Sabbath following a fellowship luncheon. A large majority of members stayed for these meetings which lasted about two hours. Throughout the eighteen months, they became a focal point in the life of the church, and general attendance did not wane during that time. These seminars had a two-fold aim. They sought first to educate the congregation into the biblical teaching on community. But second, and more important, they allowed the people present to experience community in the ongoing developing dynamic of the seminars themselves as they continued from month to month. 
To facilitate this the seminars were conducted in an informal manner which at any stage afforded a high level of interaction and freedom to talk. Though informal, the seminars were nevertheless structured and always began with the congregation divided into small groups to discuss the question presented. The purpose of the question was to bring into focus the subject of the seminar which followed. When the groups came together, a spokesman for each group would share the consensus of his group, together with any variant views, to the congregation at large.

The educational content of the seminars was presented - through the medium of an overhead projector. From the information presented in the overhead projections, participants filled in the blanks of the participation manuals with which they had been supplied. At strategic points the congregation again divided into small groups to discuss questions that arose or to give direction to the seminar as it proceeded (see sample participation manual in appendix G) .

The actual content of the participation manuals was a distillation of material gathered from course work on the Master of Divinity and Doctor of Ministry levels at Andrews University, from similar work at McCormick Theological Seminary, and from independent reading. The seminar topics were arranged in an order that would guide the congregation into dealing with specific issues in a sequential, and progressive manner. This was especially true of the first twelve seminars where each successive seminar was built on the concepts of the one before it and followed a natural line of thought. These early seminars sought to awaken a sense of the 
priesthood of all believers and to heighten the understanding that each local church community is the locus of denominational life and activity. The seminars were aimed at developing initiative from within the church for all aspects of koinonia and service.

The order of later seminars was not so critical. The aim for these was to equip the church members with various skills and an understanding of how to cope with different aspects of living and service. The material for these alternated between subjects of a theological nature and those of a practical nature, but all related to real issues faced by the parishioners in their everyday lives--whether as people facing stress or as Christians in witness. A brief description of each seminar, stating its purpose, theme, and effectiveness, follows:

\section{Group Dynamics and Human Relationships}

Since the church was going to be doing much of its work as small groups, it was decided that this seminar should convene at the outset of the overall project to develop skills in communication. Since the topic was new to most people it proved to be extremely enjoyable as well as effective.

2. The Nature of the Church

The church is not primarily institutional in essence nor hierarchical in structure: it is centered in the people of God as a local community. The church responded well to these concepts. 3. The Laity and the Clergy

The artificial and unbiblical distinction between "laity" and "clergy" was disclosed and the priesthood of all believers established. The topic was closely associated conceptually with the 
previous seminar, and the response was very similar.

\section{Baptism}

An outline of the theology of baptism was presented preliminary to the concept that baptism involved incorporation into the Holy Spirit with His sovereignly distributed gifts. This seminar was necessary but its intended significance was not seen by all of the participants.

\section{Spiritual Gifts}

This seminar was divided into three sessions. The first outlined the basic theology of spiritual gifts. The second endeavored to help each individual discover his or her spiritual gifts. The medium used was a questionnaire of 130 questions. The third presented a group exercise in which each member's perception of his spiritual gift was tested in a supportive way by the experience and perceptions of the church at large. Of all the seminars this proved to be the most popular and effective. The third session was powerful in its effect of koinonia. Being foreign to the experience of most of the church members it took them a while to enter into the real purpose of the seminar. Many people were reluctant or unable to confront an individual with his or her misperception of his or her own gift. Eventually this was achieved in a beautifully supportive eay. The congregation felt very close emotional ties at the end of this seminar.

\section{The Role of Your Pastor}

Twenty different role conflicts experienced by the minister and complicated by differing expectations from individual church members, the church as a whole, the conference president, the 
community, the pastor's own family, and his personal concepts of meaningful ministry were explored and documented (see appendix $\mathrm{H}$ ). A negotiated contract was drawn up with the church in the form of a verbal understanding of the pastor's priorities, especially in the area of mission. This proved very helpful and profitable. Very few people had any conception of the breadth of a pastor's work. 7. Mission

The history, theology, and nature of mission were discussed in a practical way, and the three-fold emphasis of proclamation, service, and fellowship was accentuated. This seminar was more theological in nature and did not seem to have the deep emotional or practical impact on the hearers as some of the previous subjects. 8. A Case Study of Mission in the S.E. California Conference

Results of the theology of mission applied to a contemporary situation were studied and the factors inhibiting and facilitating successful mission were documented on a resistance-receptivity Axis diagram. This seminar proved extremely interesting to the participants and provoked a lot of discussion on the relative effectiveness of different evangelistic methods.

\section{Establishing Our Mandate for Existence}

A Statement of Mission was drawn up by consensus of the local church. This was done after attending the eight previous seminars and by distilling the principles learned into something relevant to the present situation (see appendix I). The two sessions for this seminar proved to be the most arduous of the whole series. They required a lot of concentration and the slow, laborious process of arriving at a consensus was difficult for many of the church 
members. Since they had largely been used to directives in the past, they found the whole concept was new and somewhat painful. Nevertheless, when the task was completed, a very effective and complete statement of mission resulted.

10. Examination of Our Glen Ellyn Church Growth Patterns and History, and the Characteristics of Its Surrounding Environment

Charts were drawn up of yearly rates of growth, actual growth, and gains and losses. The factors that facilitated early growth and inhibited later growth were discussed in light of the history of the church. Relevant statistics of the surrounding local area were studied from the 1970 Census figures (see appendix J). This session was somewhat difficult for some of the long-time members, but it was very informative for the newer members as painful incidents from the formative years of the church were sensitively discussed.

\section{Establishing Specific Goals}

The church set specific goals in the area of koinonia, proclamation, and service for the next twelve months (see appendix R). Of all the seminars this one demonstrated the most conflict. The wide range of interests and different ideological approaches to mission work made it difficult to keep goals specific, attainable, measurable, and realistic.

\section{Koinonia}

The bibical concepts of the common elements in church life were shared and a group experience was entered into to enable church members to taste this commonness at a deeper level. This was very much needed after the previous seminar and proved quite helpful. 


\section{Caring for Persons: Skills in Helping}

This was more of a workshop than a theological seminar. Insights from the behavioral sciences in problem solving and in dealing with conflict were used to create role plays and exercises to enable members to practice and develop skills of helping in reallife situations of community. This was a fun time as well as a training time and was one of the most helpful sessions of the whole series.

\section{Justification by Faith Alone}

This seminar dealt with the relationship of the doctrine of justification to sanctification as a polemic against perfectionism. It was purely theological but received with avid interest and provided a good balance to the previous practical sessions.

\section{The Journey of Faith}

In a further extension of the work of Piaget and kohlberg (by Jim Fowler and Sam Keen ${ }^{1}$ ), six different stages of development of faith in the lives of children through to mature Christianity were examined for the benefit of parents and Sabbath School teachers. This was the first seminar to deal with real-life situations and was received very well, even with deep emotion by some. 16. The Theology of Marriage

The biblical perspectives on marriage were considered under the headings of revelation, God, sin, Christ, salvation, the church, and the last days. The very restrictive view taken on divorce

${ }^{I}$ Jim Fowler and Sam Keen, Life Maps; A Journey of Faith

(Waco, Texas: Word Inc., 1978). 
created opposition on the part of some, but in the overall picture, the seminar was very effective.

17. What Our Church Historians Are Discovering about How the Spiritual Gifts Given to Ellen White Actually Worked

The problems posed by Ellen White's literary borrowing and her disclaimers on historical and theological infallibility were addressed through a discussion on the minutes of the 1919 Bible Conference and the article by Donald McAdams, Spectrum, Vol. 10, No. 4, "Shifting Views of Inspiration: Ellen G. White Studies in the 1970s". Some feared this issue would be too sensitive to deal with, but all present craved an openness on the subject and expressed deep, genuine appreciation for the material presented. 18. The Sabbath and Justification by Faith Alone

The way in which the Sabbath can forcefully express justification as a central pillar of Christianity was dealt with in conjunction with the correctness of the seventh day as the Sabbath. Although theological in content; this presentation was well-accepted by the church members.

19. Worship

The history of worship practices from the time of the patriarchs to this present day was considered. Different orders of service were studied and a specific order was drawn up to suit the needs of the local church. This seminar extended over three weeks and like the session on drawing up a mandate it proved arduous and provoked arguments because of the differing needs and viewpoints. Some aspects of the resultant order of service, especially the sung responses, were not readily accepted. 
20. Revision of Specific Goals

The earlier goals established in March 1979 were assessed and revised in November for the following twelve months. A more realistic set of goals were established on this occasion.

\section{Practicum in Sharing the Gospel}

Following a viewing of the film "Ben Trying", a case study from the actual life of the congregation was examined through role play. The most effective way to have shared the gospel in the specific set of circumstances was discussed. This seminar was deeply appreciated and many requested a repeat of this type of program.

\section{How to Study the Bible}

The various tools for Bible study--whether theme by theme or book by book--were discussed, both for beginners and advanced students. This study met with a good response, and several members purchased concordances, dictionaries, and commentaries to aid them in a rejuvenated program of self-study.

\section{Prayer}

The nature of prayer was considered under the rubric of need, thankfulness, and God's covenant loyalty. The Lord's Prayer was examined in the light of these principles. This was an effective seminar.

\section{Practicum in Sharing the Gospel}

This was a repeat of seminar 21 , but a case study from the congregation was used rather than a role play (which the members had previously found hard to relate to). The ensuing discussion proved very provocative. 
25. Understanding the Mid-Iife Crisis

This seminar discussed the various dynamics of mid-life as presented in the works of $\mathrm{Jim}_{\text {Conway }}{ }^{2}$ and Gail Sheehy ${ }^{2}$. It proved extremely practical and revealed a deep need among the members to deal with psychological, emotional issues that people have to encounter in the daily stress of life.

26. Understanding Old Age

The factors that old people have to encounter were discussed in the light of how members may both bring happiness to the elderly and prepare for old age themselves. Some members found it painful to face their advancing age and mortality, but generally this seminar was well received and effective.

Following the seminar on Koinonia, meetings were begun 7 May 1980 and subsequent Wednesday evenings to develop the Koinonia experience among church members. These meetings were held in the church or at various homes of members and had an average attendance of about ten.

The meetings were conducted along the lines of the six steps of shared Christian praxis developed by Thomas H. Groome ${ }^{3}$ of Boston College, Massachusetts. The first step comprised a focussing activity in which a passage of scripture was read slowly and expressively. The second step was an invitation to the participants to

${ }^{1}$ Jim Conway, Men in Mid-Life Crisis (Elgin, Illinois: David c. Cook Publishing Co., 1978).

${ }^{2}$ Gail Sheehy, Passages (New York: E. P. Dutton \& Company, Inc., 1976).

3T. H. Groome, Christian Religious Education: Sharing Our Story and Vision (San Francisco: Harper \& Rwo, 1980), pp. 184ff. 
name their own "knowing" about this passage. Rather than expressing what they or the church or society thought this passage meant, they were encouraged to name their own feelings about the passage and express what the passage said to them and to their lives. The third step involved a critical reflection on the passage of scripture, which, together with the second step, involves a strong praxis approach to knowing. This step was facilitated by asking each person: (a) "What memories does this passage conjure up for you?" and (b) "What hopes and visions do you hear this passage calling you to?" The fourth step "shifted gears" and involved a "theoria" approach to knowing--Groome's technical term for that type of learning coming from an awareness of what others have learnt before us, as distinguished from our own experiential learning. Here the knowing of the broader community was shared with the group by the leader. The members' "story and vision" (a technical term for what the scriptural passage meant to each individual and what they heard it calling them to in their lives) was supplemented by "The story and Vision" (an exegetical understanding of the scriptural passage and God's call to man through that understanding). This section was short but needed to be done thoroughly and in a well-informed manner. It was the moment of teaching as all the insights of thorough exegesis on the passage and its application to our social situation today were shared with the group. It was important to make all this available to participants so that they could appropriate it and dialogue would not be cut off. The fifth step gave the participants an opportunity to appropriate the theoria of 
"The Story" into the praxis of "their story" through dialogue between the two. This idea is an attempt to see the why of "The Story" and can be elicited by asking, "What in this presentation made sense to you?" The sixth and final step was a dialogue between "The Vision" in "The Story" with their visions. Here again is an opportunity for decision making and asks people to act or respond to their new knowing. It can be facilitated by asking, "What impact do you want this to have on your life?"

Even though these six steps formed a structured process they provided a framework for understanding in the group and a strong supportive atmosphere where people gradually felt free to express their needs before the group in a secure way developed. The meetings always closed with a conversational form of prayer ${ }^{1}$ in which anyone could express his or her petitions at any stage as many times as desired.

A church wedding provided an ideal opportunity to implement some of the principles of koinonia. A sermon on how Christ brings tones of reconciliation into a marriage was preached the Sabbath before the wedding. Following the sermon, the couple came and sat in the center of the church and the congregation sat in a circle around them. A moving season of prayer in which many of the parishioners upheld the couple in supportive petition and welcomed a new home unit into the koinonia followed. The groom's marriage vows (see appendix $L$ ), which he composed and expressed at the

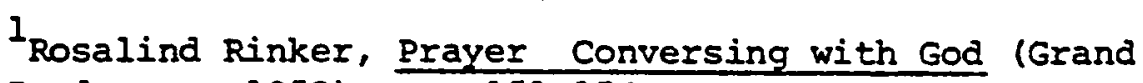
Rapids: Zondervan, 1959), Pp. 151-154. 
nuptial, revealed good insight into the theology of reconciliation. Another opportunity to bring out the principles of koinonia arose when the head elder announced his impending transfer, and a successor was elected. A sermon on the biblical view of the role of the community in choosing church officers was examined. After the sermon, the new elder came and sat in the middle of the circle of parishioners. The membership was small enough so that each person who felt inclined could come and lay hands on him and thus have a part in ordaining him to leadership. It was an effective and practical way of bringing out the theological principles.

The Experience of the Church in Mission

A ministry of reconciliation by the members was facilitated in various ways. The main revitalization came from the understanding, motivation, and direction of the Sabbath afternoon seminars. It was recognized that another "program" or "soul winning training session" was not the answer. In the past such programs had largely failed to activate the church. Desmond Ford has pointed out, in response to the report of the General Conference in Vienna, that over 90 percent of the Adventist membership has no record of soulwinning activities, that the average for Bible studies is one Bible study per person per year, that the equivalent of approximately one whole world division is lost to apostasy each year, and that ". . the real reason why people in our churches are not enthusiastic, overflowing, witnessing with the gospel, is because they are not sure themselves that they are right with God."I

${ }^{1}$ Desmond Ford, "The Valley of Desperation," Australasian Record, August 29, 1977, p. 10. 
The quintessence of the author's struggle over this problem is reflected in "One Man's Odyssey" published several years ago. 1 Consistent with this, the dominating, almost obsessive, purpose of each Sabbath sermon, pastoral visit, counselling session, discussion group, koinonia meeting, and seminar was to convey the assurance of salvation through sharing the essence and meaning of God's completed act of reconciliation.

The secondary purpose of the seminars was to channel the new found spiritual energy that always comes from understanding this truth into lines that were compatible with the spiritual gifts given to each believer. The first six seminars were preliminary to this end, but the next five specifically dealt with the theory and practice of mission.

These processes carried on in community were reinforced in personal pastoral visitation. Ways for each of the parishioners to exercise his or her spiritual gifts in specific instances were discussed on these occasions and encouragement to begin was given. Some of the responses included a Natural Foods Cookery Class, the continuation of stop Smoking clinics, the conducting of an organic gardening class, the organization of children's meetings during a subsequent evangelistic program, the commencement of a women's morning study group, study programs from the New Earth Vegetarian Restaurant in nearby Wheaton, the opening of homes for social functions organized around service, the creative use of art and

IG. S. Loftus, "One Man's Odyssey," Australasian Record, October 15, 1979, pp. 1, 2. 
photography as a medium of the message of reconciliation, the spontaneous support of needy persons within and without the church, and individual Bible studies with friends and work companions.

On Wednesday, 13 August, an evangelistic seminar on "Studies in Daniel" was initiated for the public in the Holiday Inn at Glen Ellyn one night a week for ten weeks. These seminars were not restricted to a study of prophecy but were deliberately slanted towards proclaiming God's act of reconciliation. Each night dealt with a successive chapter in the book of Daniel, which consistently lends itself to this theme through the central place the sanctuary occupies in its theology. Each night the words "Justification by Faith Alone" were written on a chalkboard and, without trying to artificially impose Pauline thought on Daniel's theology, New Testament principles were also drawn out. Personal testimonies of those who attended revealed that studying the book of Daniel with the emphasis on the theme of justification was largely responsible for the success of the program. From the teacher's point of view it was the only thing which made it consistent with a ministry of reconciliation.

Some forty non-Adventists attended regularly for the whole series, and many of these followed a series of Revelation lectures held in the nearby Elmhurst Church by evangelist Mark Finley of the Lake Union Soul Winning Institute. Of those who attended the Glen Ellyn Daniel seminars, ten were baptized into either the Glen Ellyn or Elmhurst Churches; an additional five were still worshipping each Sabbath as of April 1981. Church members responded well to the 
seminars and several gave travel assistance to those who had no means of transportation.

The series of Revelation lectures held in the Elmhurst Church introduced the members to this form of evangelism. The Glen Ellyn members successfully negotiated Elder Finley's services for a similar series to be conducted in Glen Ellyn during the fall of 1981.

The Sixteen Personality Factor Test and the Motivation Analysis Tests were found to be useful instruments in the ministry of reconciliation for those who were not church members. Many. people who attended the Daniel seminars and Revelation lectures were experiencing difficulties in their marriage relationships or in their general approach to life. These responded readily to suggestions to take the tests. This exercise enabled the pastoral staff to sit down with these people and interpret the results of the test. It provided an ideal framework in which to address in a very effective way the issues of reconciliation to the specific needs in the people's lives. As a result, two couples and one divorced person gained a deeper measure of healing in their relationships. They began to attend church and to live together in greater understanding and awareness of each other.

\section{Evaluation}

By the Church

Examination of the written evaluations finds a mixed response to the project in its different ohases. This was born out fairly consistently in any conversations that took place in pastoral visitation and the general matrix of church life. 
of the twenty respondents, eleven seem to have exhibited a genuine understanding of the principles conveyed and revealed evidence of a tangible impact on different aspects of their lives. of the other nine, four seem to have partially grasped the concepts and reveal a limited corporation of these principles into their lives. Of the five remaining members, three appear to have remained completely unaffected by the project and two to have set themselves militantly against the principles involved. They have demonstrated their feelings by emotional withdrawal or aggressive confrontation on different occasions.

It seems fitting to record a few selected responses to the questions on the evaluation sheet that specifically illustrate these tentative conclusions.

QUESTION I DO you think you have a clearer mental understanding of God's act of reconciliation with the human race than you did eighteen months ago? Share with me what your understanding is at this time?

Responses which reflect a positive understanding of the underlying theology of the project are:

God is Father personified. I can now lay claim to all the rights and privileges of a child of God.

YES! For the first time in my life I understand what the gospel of Jesus Christ is 211 about. Jesus has already saved me! My salvation is secure through His living and dying and I don't have to worry about it, not ever. I am free to be me! God does not condemn me. Therefore I do not condemn myself or anyone. (In condemning I would exhibit disbelief). The cross has never been so clear to me as it is now. I love Jesus because He gave me an escape from certain death through His own cruel death. I want to follow Jesus and let Him direct my life daily, because I realize the significance of His life and His death. I don't have to do anything to be saved. I am saved because I believe in and accept the gospel of Jesus Christ. 
Now I do the will of God because I want to (not because I have to). When I see how much Christ lived for me and how much He suffered for me, I cannot help but love Him. Because I love Him I love to do His will.

I guess that the awareness of what God has done for me has dawned gradually over the past $18 \mathrm{mo}$. I knew before that Jesus' life and death were necessary to reconcile God and man, but it has only been in the past $18 \mathrm{mo}$. that I have come to see that as a personal, real, elemental fact in my life. It has been a great mental struggle to give up the idea that I had to do something to merit favor with God. (This, by the way, I am coming to see as a view of colossal egotism). It has been the revelation of the incredible love and character of God, in its many reflections, and subtleties, and unimagineable splendor, that has convinced me that I can do nothing to "make points" with Him. It has been contemplation of the character and love of God, especially as reflected in the life of Jesus, that has convinced me of my own abject sinfulness.

To put it simply (and that is the only way I understand it right now), my understanding of the reconciliation effected with God by the life and death of Jesus is this: The only merit that I can claim before God is that of my substitute, Jesus. He bore every bit of condemnation that I deserve. When God looks at me he doesn't see my sinfulness, but the perfect life of Jesus that I have claimed.

I see the relationship of obedience as this: the only response to the love that God has shown to me is loving Him in return. This has to include doing tis will as He has revealed it. As I contemplate the cross, how can I want to hurt Him? I realize that my living is horribly imperfect, and I think that only a better understanding of the cross and the love it reveals is the solution.

His act of atonement for mankind is our only hope now, during the judgment and for eternity.

Jesus is much better than I had understood and I am much worse, which I always suspected . . My reconciliation with God is not something to be hoped for and prayed for. It is a fact when I accept the free gift of His son.

Who am I that through His perfect life my life is justified? - . Who am I, so imperfect, become perfect through His righteousness? . . . He said: "I love you; trust Me." I said, "I do; forgive me."

Justification is a verdict of not guilty. It comes by recognizing our continuing debt to God's law and counting Jesus' righteous life and death as our own. The righteousness of Jesus that justifies us is alien and cannot be confused with the righteous living He works within us. 
I understand that "God sent the Son into the world, not to condemn the world but that the world might be saved through Him." Jesus is our Redeemer and our Substitute. Salvation was accomplished through the living and dying of Jesus and all we have to do is accept that. We can add nothing to it.

These responses offer some insight into the parishioners' understanding of God's act of reconciliation. They are heavily weighted towards a forensic concept of justification and generally miss the theological nuance of alienation and reconciliation. In practical terms, however, the heightened awareness of justification led to a real grasp of the implication of reconciliation and that was revealed in the responses given to the later questions.

Statements which reveal a cautious attitude toward the theology of the project, and even basic rejection, are seen in the following responses. The first statement reveals a basic lack of assurance of salvation, while the second blatantly confuses gospel with law.

I have found my self-condemnation to be less but also I have a sneaking suspicion I'm getting away with something. Like its too good to be true. . . like a school boy on a holiday soon to end... it gnaws at my joy-but slightly.

The seeds of the gospel are IN the law. The law is not something different than the gospel in the end. When we say that the law and the gospel are different sides of the coin, there is still just one coin. The apostle Paul seems to illustrate this principle in Romans 7. Without the seed-power of "Thou shalt not covet" he would never have had such a full flowering personally in the gospel.

Jesus, the CREATOR, has illustrated this principle in nature, through biological transmutations if you are familiar with them. Louis Kervan has written a book giving examples. Basically, for example, there can be chickens without any potassium in their diet-potassium deficient. They are then fed some feed that has no potassium in it, but say, only iron. Upon chemical analysis it is found that the deficiency in potassium is gone, and the amount of iron ingested has "disappeared". Somehow, the iron has transmuted, through the living chicken, into potassium. The law transmutes into the gospel. 
QUESTION II Has your understanding of God's act of reconciliation with us through the living and dying of Jesus made any significant difference to your own private way of living in the past eighteen months? Have you had any personal crises in your life during this time that you could risk sharing, specifically including how you dealt with them? Have you been able to deal with feelings of guilt, rejection, or other bad feelings about yourself? Have you developed both an assurance that you are at present in a saving relationship with God, as well as a sense of self-acceptance? Have you discovered any spiritual gift He has given you?

Perhaps the clearest insights and effective outworking of

the principles of reconciliation were seen in the following response.

It expresses beautifully the insight the gospel brings to a person

who has been living by a perfectionistic framework.

The past eighteen months have been unusual. The concepts listed under QUESTION I were not my first thoughts about God. I had a framework for my relationship with God-mostly a form of legalism, which I had entered into 5 years ago. To be completely honest, I feel I approached God sincerely and with a teachable spirit. I attempted to please God in my dress, work, worship (Sabbath observance), relationships with others, with my health habits. And if success could be rated by comparison, or with degree of change, I was successful. But life being what it is, the inadequacy and futility of that framework began to become apparent. It just didn't work. The result: I felt guilty-maybe I hadn't done enough, and until I could be better God couldn't bless or accept me. Why was I so sinful? I felt like a failure with God. I felt rebellious-the only virtue I thought I had was that I had come to God and he had let my life get totally messed up. Was He impotent? Did he care about me? I have never, or at least can't remember, feeling worse about myself or more frustratingly angry. So the framework presented at the G.E. church has to fit into that. I believe that anyone who truly has some margin of self-knowledge would find the gospel philosophically perfect. It ties everything together (the reality of our condition + God's love and acceptance of us), in a wonderful surprise ending-we are salvageable wherever we encounter God.

But I had a deep distrust by this time of ever solving the problems of my existence and wasn't sure I wanted to risk another theological framework, that last one was so disastrous and I was still bruised and bleeding from it. So at times I have been unwilling to accept the gospel. Life demands a reason, and if there was no God then life was meaningless. And if there was a God then the God of the gospel was certainly the most appealing to the reality of the human condition. So at 
times I was willing to accept the gospel. The gospel provides much more freedom and coming from a very legal framework I sometimes felt as if it was appealing but didn't have enough substance. Take loneliness. When you are lonely and legal there is something you can do. (1) Feel guilty-after all, isn't Christ enough? So feelings of loneliness can be dismissed. (2) Do something for someone else-its only because you are so self-centered and sinful that you feel lonely, if you get busy you'll be okay. (I do feel that there is some truth in the action taken here, even if the motivation is not correct). With the gospel and my past experience I found myself in a different frame of mind. I wasn't willing to overlook my immediate condition. God loves me, Jesus died for me, I am reconciled to God, there are angels in heaven that love $m e$, and I am lonely. I am lonely because I was created in the image of God and need fellowship and companionship to be complete. My condition was not unnatural or sinful. This is very hard for me to get together. This is the conclusion I've reached at this point. The gospel leads you to deal directly with problems. God is ultimate reality and because He is for you, any problem in my life can be looked straight in the eye and dealt with-it fits somewhere. Because of God's wonderful reality as shown in Jesus He is my top priority. When I get an attack of loneliness I take it to Him and tell Him what's happening. I rehearse the gospel facts sometimes, and sometimes I accept the fact that He still loves me by faith alone with no emotional tie in at all, and I ask that He would strengthen me not to meet my needs myself, like Abraham and Hagar. This really seems to work. The one pitfall I see in directly facing your problems is that you can go overboard into self-pity. The gospel brings you back on course because if God is for you, who can be against you? I guess it is a surprise to me that the gospel, which is often seen as dangerous because it doesn't demand enough human performance, has led me to a more aggressive, active way of life. There's another comment I need to make that I believe fits in here. In the last 18 months I have "sinned" more frequently that in the prior 18 months. I have done things I previously held to be wrong. I've eaten ice cream, pizza-eaten occasionally between meals, bought some shoes I thought were pretty, on down the line to some heavy duty, hard core transgressions. Some of these things were done from a rejection of legalism, some from a sense of freedom, and some in complete rebellion. I'm finding that believing the gospel and reading the Bible are helping me to find true values. I write this to indicate a person's outward life may not be the indication of whether the gospel is taking root, although I am convinced it will prove ultimate acceptance.

What God has done for us is certainly wonderful. 
Another clear insight came from a woman who had suffered a

serious illness during the eighteen months and had been brought near

death.

Many times over the past years I have wanted to "run" from life or perhaps I should say "my life." This spring and early sumer I did run by becoming weak and sick. I believe God allowed this so that all my doubts and fears about life, as I seemed to be living it, had a chance to rise to the surface, and I had to take a good look at them.

I do not feel rejected by God-by man, yes, and am still struggling with acceptance of self.

Other positive responses include the following statements:

Their (friends) unconditional acceptance of me and their spiritual walk reminded me continually how God viewed me, how I was to view myself and others. God knew that my confidence in myself was conditional.

The greatest single change in my life has been that I no longer fear the future and what the course of my life will be.

Even greater than that, as I think about it, and the thing that any other change must spring from, is that I have a genuine sense of self-worth for the first time in my life. I say genuine because I had a false sense before, based on human pride and ego. As I realize the love that God has for me, as shown through Jesus' life and death, I realize how much I must be worth to God. I look back on how He was calling to me all of my life, and am amazed at His patience. This sense of selfacceptance because of God's acceptance is tremendously important to me. I've always wanted acceptance so much, and sought it in many unsuitable ways. I can resist the crowd more, which makes me very happy.

I do have a feeling of assurance of my acceptance with God, although there are times when this feeling makes me feel guilty. I feel that I don't deserve it, and probably should be worrying more. I very much don't want to be smug.

I almost divorced by husband because I would not appreciate his way of thinking and behavior. I had also decided to forget about church and wanted to change the direction in my life completely, including friends and family and religion. I blamed my ignorance for everything ( $I$ mean the lack of knowledge and understanding) and felt unwanted by anyone. As I listened to the new messages from your podium I began to more fully understand God's love for me, and also began to feel better about myself and realized I was worth something. I was able to forgive my husband as well and recognize some worth in him too. Because I realized that God recognizes my worth, I knew that I 
had to be willing to let Him help me recognize the worth of my husband and other family members, and consequently my marriage and home was reunited. We have a long way to go yet, but things are so much better than before and I am so grateful

Looking and longing a lifetime for the words that dispel the heart's fear of rejection is in one word, "Relief."

Understanding the cross has aided me in courting and entering the marriage covenant. I constantly need to hear the message of forgiveness to combat feelings of guilt and rejection.

Responses that revealed a failure to incorporate God's act of reconciliation into the personal life seemed to center mainly around fear that this theology opened the gate to cheap grace and even libertinism. Typical of such concerns were the following:

There has been a lack of works brought up in these seminars as I perceive them and almost to the point of "beware of works because you can't work your way into heaven."

The loophole that haunts away from the perfect assurance of His saving grace is obedience. I have an idea of what you believe but maybe a person like me can benefit more since it radiates into our relationship with Him, service, Christian walk, etc.

I believe it is an integral part of salvation as displayed in the beginning--Gen 2:17--where by eating of fruit resulted in death all the way to the rich young man asking Jesus what to do to have eternal life in Matt 19:21. Even though I know that the law is made to condemn us and helps us to realize how much we need the gospel, I sense that the act of trying to obey the laws of God is almost a tabooed act. I realize (by now) that Adventism has swung too hard in the pendulous direction of sanctification and salvation through works. I believe God wants and expects us to try (there is victory in acting it sometimes) and with the promise that the Holy spirit will help us to keep the law (and I don't mean perfectly) Rom 8:4.

I know your loving relationship with God has caused you to love to obey Him and His laws, but I feel emphatic about the law for the complacent that axe bathing contentedly in His blood. If we know Him we keep His commandments (1 Jn $2: 4$ ).

I have gone through a degree of confusion of almost saying go ahead and do things God has forbidden; His grace will cover us anyway. 
Ninety percent of me feels I shall endure. Ten percent says you are fooling yourself. In terms of behavior its definitely worse but I'm not too concerned. I think it is in limbo due to transition of governments in my mind. I expect Christ to take over in my behavior any day now. I see my failure but I refuse to lower the standards of behavior Christ wants for me.

Two others demonstrated confusion and lack of assurance when it came to their relationship with God:

I'm not really sure if I have developed an assurance that I'm saved or in a saving relationship with God. Yes, I think I do accept myself, but I'm not really sure.

2 Cor 5:17 gives me problems. "Therefore, if any man is in Christ he is a new creature... (And further)... (2 $\operatorname{cor} 5$ : 20) "We beg you on behalf of Christ, be reconciled to God." This is a two-edged sword: I see it as a declaration, as well as a responsibility or evidence. I see nothing but my faults and continuing sins . . . if being a new creature is an "evidence" I'm in trouble because my "evidence" takes me back to court and I'm found guilty again and again and again. I realize that this act of santification is necessary but $I$ see myself as not making headway. I constantly have to cling to Jesus and keep rny eyes shut. I sometimes think He allows me to sin so I can cling closer. If I have a problem, its how to change my bad habits and turn away from evil: not to gain favor but to feel less a hypocrite-its this hypocrisy that is a block for me to preach/ reach the unsaved. I know that even by my own standards I'll never be "good enough" but I sure would like to see some progress. To me, lack of progress means backsliding and then I start doubting my relationship to Jesus and just how sincere it is. See the circle? Know how to break it? God is not mocked; I accept His love and acceptance as a richer gift than anything a man can give... I only wish I wouldn't disappoint Him so, you hate to disappoint anyone you love and loves you! How much greater the disappointment to someone who can love you perfectly. I can accept this perfect acceptance (its the only thing that keeps me sane) but shouldn't it be transforming as well? What's wrong? I know God is for me . . But I question the depth of my following of $\mathrm{Him}$.

One statement revealed a radical failure to grasp the bles-

sings of God's act of reconciliation:

I believe God loves me. But I'm not sure He'll save me because I'm such a rebel. That thing (an incident) was just the tip of the iceberg. I love God's principles and Christ is my hero, but I have a strong sense of pragmatism and situation ethics that is constantly at war with them. Sometimes I think 
God will tenderly kill me when judgment comes. And I'll deserve it. He is good and righteous. I wouldn't want to jeopardize heaven myself.

QUESTION III Has your understanding of God's act of reconciliation through the living and dying of Jesus had any noticeable effect on your ability to experience reconciliation with other church or family members? Are you better able to accept others in the church or your family with whom you may have had open or unspoken conflict in the past? Are there any specific concrete examples of this you can give without necessarily disclosing names if you don't wish to'? Do you feel that the Koinonia (spiritual fellowship, sense of community) has increased in our church over the past eighteen months? In what ways?

Positive responses to this aspect of reconciliation are

revealed in the following:

There seems to be more openness of feelings, more willingness to show affection for each other.

The most important change in my attitude towards other has been the knowledge that unconditional acceptance is essential in my relationships with others. I did not hold this position before. It appears clear and unrefutable to me now, whereas in the past I have easily justified my rejection of some people.

I have a tendency toward criticism, and condemnation comes easy. Now I am committed to accepting everyone as worthy of my acceptance because of the value humans have since Jesus died for all. This is tremendously hard for me to put into practice and the examples I would give would seem very insignificant compared to the majesty of the concept.

Basically, the way I've tried to show my acceptance of others is by not rejecting them. I often feel uncomfortable when I am doing this, because I've been used to making so many judgments. I find myself thinking about how I can show others I accept them and still be honest myself. In other words-to accept where they are and not let it cinange me. It has always been too threatening to do that in the past and this is where the gospel is amazing because it frees me to accept and be myself and to accept others, even when we are different. Eph 2: 16,17 is really a good summary of this.

The basic tension I feel from the fellowship is when I feel I'm not accepted because I'm not willing to see things the way someone else does. Basically in our church I pick that up from only 1 or 2 people. 
This concept of unconditional acceptance is exciting to me. I believe it has made a big difference between myself and my parents and brothers and sisters. I am depending on it to pave the way for me to present the gospel to them.

Yes-friendliness-genuine concern for each other-we even bring things to fellowship luncheons that we know will please everyone, including those who are especially concerned about natural food goodness and nutrition. We are all careful to bring dishes with less starch, more protein, no sugar, etc. I think our Glen Ellyn Church potlucks are entirely different from other Adventist Churches. We all feel a concern for each other which brings us close to each other like a family. The small church group is the secret of koinonia I believe. Most of us, most of the time, feel free to express our thoughts and feelings even though we know there is the possibility of rejection (I mean rejection of ideas, not a person). I need to work on this myself; but I notice that others express themselves freely without fear of being personally rejected and I admire that quality in them.

God's love helps me love and accept my parents in a way I could not do before. My mom and I are a lot closer than before these eighteen months.

When I began to keep the Sabbath I became bitter against those Christians not accepting this truth when presented to them. Through the constant hearing of justification by faith I an gradually becoming more accepting of those who adopt other views.

We are learning more about each other through the seminars and the spirit of God is silently carving the corporate clay.

My understanding of God's act of reconciliation to man (i.e., me) through the life and death of Jesus has helped me in my dealings with people, in general, and my family (church and biological), in specific, by making me more tolerant of people. Part of accepting the message of justification by faith is realizing that $I$ am a sinner, and that my first sin (indeed my nature) rendered my totally unfit for the company of God. Realizing this makes me very aware that I cannot judge others. In fact, I believe that judging others is blasphemy, because judgment is the prerogative of God alone.

This has helped me a great deal in my relationships with others. In fact, this is the only thing that helps me overcome my incredible natural arrogance. There is one example that I can use, from within our church family. There is someone within the congregation with whom I have always had a hard getting along. I'm afraid that I was very rude on occasions. Then, during a sermon one sabbath you went through the ten commandments in great detail. When I thought about how completely I had broken the law, and yet God has forgiven me because of the life \& death of 
Jesus, I realized how rotten I had been. I asked this person's forgiveness, and things have been better from that point onward. We still aren't best friends, but...

I do recall an incident in which, because of the circumstances, involved, re-evaluation was required. I believe it was a test for both this member and me. Even though I believed injustice and non-Christlike actions were present, I tried picturing this person's life and problems which helped me to better understand, accept, forgive, and love, in spite of what happened. The problem involved my paying several hundred dollars (which could have been alleviated by much less cost, if any). I would never have asked the person to pay if I were in his/her situation. The Lord taught me to love that person by picturing how He viewed him/her. There is always victory in Christ. I believe what happened has affected and changed this person's life in relation to me and God. What was guilt (and maybe there still is) on his/her part, has developed into a beautiful "koinonia" relationship between he/she and me.

All of a sudden we're in the same boat-equals, equally priceless.

I've found recently, though, that discipline can be love too: "Those whom I love, I rebuke and chasten." Also: "Be as kind (harmless) as a dove and wise as a serpent"-you have to have wisdom to soften rebuke with loving concern (or keep out of the correction business). How wonderful it is to have a Redeemer who cares for man's fragility, and what a lesson study this is for His character.

A particular member was driving me crazy for a long time, but recently I decided to just accept her as my Savior has accepted me. My feelings of holier-than-thou have diminished somewhat to better understanding God's perfection and His holiness-that one's attempts at holiness though needed, can't be "lorded" over someone else, because no matter how sanctified we are, we fall infinitely short of the standard. We can not judge. Conversely, all who are in Jesus are perfect in Him and are accepted, so not accepting another is denying Christ's acceptance for others or His ability to save. To accept your own acceptance and not another's is to deny the entire Christ redemption senario.

There were three responses that revealed a failure to understand the basis of or to enter into the experience of koinonia. The first stated that she believed koinonia had caught on well, but then paradoxically revealed an inability to join in that experience. This 
was evident in a physical and emotional withdrawal from the seminars and the following plaintive expression of loneliness and a burdened outlook on life.

I have a few questions, one or so is somewhat burdensome to my heart, I just wish I could unburden my thoughts to someone, I may not be necessarily right in my thinking, but I wouldn't know unless I am able to communicate my thoughts to someone, and have a discussion on these matters. Many times things arise that could cause discord mostly because of my outspoken nature, however, I sense the tragic situation, and where all this could lead, so I oft times try to shun the evil, take the problems to the Lord in prayer, and I am able to overcome. Hence, no problems getting along with others. I don't know about others and me.

The second assumed that the basis of koinonia was the essential loveliness of man and in his church relationships demanded that koinonia overlook completely his personality deficiencies whatever they might be. He felt that koinonia had increased in the church - . in giving us impetus to open up to each other. To know is to love... I will have no relationship that dwells in the miasma of discontent and disapproval.

The third failed to enter into the koinonia of the church at any stage. He continually stood apart from the body of Christ in a private relationship with God alone and repeatedly took a prophetic stance against the members of the church. The pastor often had to minister in a healing way to such members and often had his own theology of reconciliation tested by statements written to him, such as the following:

I sense in this evaluation the type of evil present when David wanted to number Israel. (You have asked me to be honest and a man is nothing if not honest). So let me quickly first say "positive" things: you preach the gospel and your flock loves you. 
I'm afraid, human nature being what it is, that you're going to get a lot of praise in these evaluations, so I am here as one to remind you that after you have done all, you are still an unprofitable servant. The fruit of the gospel comes forth "by itself", so we must continue to labor in all things with the gospel and in the gospel and leave all results with God. What the people think is not pertinent if we are laboring rightly with Jesus. Laodicea means "judgment by the people"-a democracy-let every man have a say.

On one occasion this person submitted a document to the conference executive committee for consideration. The document was on prophetic interpretation on the book of Daniel relative to the judgment which he believed the Lord had revealed to him as new light, setting a date for the close of probation. The conference president subsequently appointed a three-man committee to consider its content (see appendix $M$ ). The committee duly met and following rebuttal of the doctrinal positions set forth in the manuscript, the pastor included in his reply to the author a personal letter (see appendix $\mathrm{N}$ ) setting forth the principles of koinonia and appealing to them as a basis for reconciliation in the church. The plea was largely ineffective.

QUESTION IV Has your understanding of God's act of reconciliation through the living and dying of Jesus made an appreciable impact on both your attitudes toward and work for the unreconciled (the lost) over the last eighteen months? Can you share with me any specific examples of people you have been instrumental in leading to understand, accept, and experience God's act of reconciliation? Are there any areas in ecology or society in which you have been able to effect reconciliation?

Positive responses to this question were revealed in the following:

It is in this area that I feel most abjectly guilty. I have a very small circle of non-Christian friends, and they all go out of their way to avoid speaking about spiritual things in my earshot. I'm afraid I've turned people off by the didactic way 
I used to approach witnessing. I want very much to present the gospel to people, but I need to overcome the damage that I did before. I realize that I'm not a friend at all to those I know unless I do present the good news to them. People that I know tend to come to me with problems, and I always try to point them to God, and reveal to them what I know of God's character, but I know that isn't nearly enough.

I'd like to talk more with you about this.

I have definitely felt more at ease when talking about God, Jesus Christ, prayer, my salvation, and my hope for theirs.

A lady at work, whose children have been a great disappointment to her and have blamed her for their mistakes, has confided in me. She asked me to go to the Methodist Church with her on Wednesdays (at the place where her daughter was married to one who is the cause of some of her heartache), to pray for her children and granddaughter especially. We go to pray and meditate, and after several weeks now she is seeing some results. Her son has come to her and put his arms around her and hugged her for the first time in years. The daughter and grandaughter have not shown any change at this point but she is confident they will.

My children-particularly my daughter--has needed my understanding and companionship. We've talked for long periods of time and she's expressed her feelings of guilt and rejection and despair. After explaining to her many times that God does not condemn her, how Jesus stands in our place before the Great Judge, she said "it's too good to be true." I assured her that it was true and she is beginning to believe it; I know because I've seen some changes in her life and she feels a deep sense of responsibility in bringing up her child to know and understand God. She has even invited her neighbor and friend to churcin with her.

Attitudes and work for the lost-there has been a big change here. I have been actively involved in soul-winning work in the past and with my framework of theology I considered people as souls whom I had a responsibility to give information about God and what He expects from them and tried to encourage them to come up to His standards to please Him. I evaluated my success by their rate of change, and exclusively by works.

This is now the area in which I experience the most confusion. One reason for that is that $I$ am no longer involved in a job that is directly related to soul-winning. If it is the burning desire of my fellow-workers to bring others to God it is not often verbalized, yet everyone has some degree of interest in that. It seems logical to me that I should be in a job with soul-winning as its \#l goal. Yet, the job I had where that was true, I was not successful. I'm not convinced that Bible work is my vocation. In reality, I'm good at what I am doing now. But I have my doubts about its ultimate value, considering the reality of God. I feel suspended-like I'm waiting for an answer. 
Additionally, I no longer consider it my responsibility to change people. I don't care if they wear jeans or a skirt. They are peripheral and unimportant actions of people that I am no longer out to change. I don't greet people with a "plan" in my head-but because of that I don't have the moments of satisfaction I used to when I was busy telling people "the truth". The fact is I don't know how to spread the gospel. Accepting people makes you a popular person-but I'm not sure what to do once people let down their barriers. God-talk is often not the answer, even though it is true. My position here is not quite right. I'm very sure of what I don't want to do for people. I don't want them simply baptized, or dressing right, or keeping Sabbath, or conforming to some other set of meritorious behavior standards. I don't want to give them doctrinal Bible studies that miss the source of the doctrines. I don't want to pressure them into decisions. I have a whole bunch of negatives that I'm really sure of but not much on the positive side that is working for me right now. Its coming slowly, however. I suppose its best that I'm not in some active work right now. I'd probably quit out of frustration.

I guess my understanding of my acceptance through Christ has made me less concerned over artificial barriers. I'm less afraid to read non-"Kosher" books, meet with non-"Adventist" Christians, and, in short, do a lot less running around shouting "unclean"! If I judge the validity of anything now, I judge it by its standing with the gospel rather than the "church": realizing that any church, God's remnant or otherwise, is under the same judging measuring stick; that of scripture. This has helped me better understand the place of correct (scriptural) doctrine, as all true doctrine leads back to the gospel and proceeds from it. Any false doctrine-no matter how seemingly insignificant--leads away from the cross and its finished work and eventually denies Christ. An understanding of the cross and how its utter completion was typified in the sanctuary service has helped me learn that we can be reconciled through that Iamb of God who takes away the sins of the world. How simple-how perfectly complete. I've had some experience in sharing this understanding with a person at work and I think helped him better understand how complete His acceptance is and how this acceptance is typified through all doctrines like the Sabbath, etc.- how instead of a law ready to condemn, that these are celebrations of reconciliation.

I use the gift God has given me to make the physical bread so as to draw souls to the True Bread of heaven. There is a little lady with whom I have had opportunity to share truths from the Bible.

Desiring to share the gospel in a greater way I left the business $I$ was in and came to the New Earth Restaurant. There as opportunities are opened, I try to shed light on spiritual topics. 
I am beginning to experience a desire and intense need to help people in whatever way possible. Simple things like driving a neighbor to the R.R. station or calling on the phone just to say "How are you? I've been thinking about you."

These responses reveal the seeds and existence of a ministry of reconciliation for the unsaved. The remaining responses exhibited an uncertainty about this area of life. Comments ranged all the way on a spectrum from "desire" to talk to people, to an unfocussed "living the life" before friends and family, to plain unawareness of involvement in any aspects of this type of ministry. The number of people baptized to date as the result of the members exercising their spiritual gifts at any stage of the project was two, and it may well be the lack of such criteria of "success" that caused many to feel vague in response to this question. One perceptive person wrote:

I am not afraid that I have no numbers in my society to give to my Heavenly Father. I believe He loves me without my knowledge of His fruits.

Nevertheless, it was recognized by several that this area of the project was largely unfocussed and needed to be more specific and productive in some way. One very valid criticism came in the following statement:

At first I was thinking mainly about what direction should be taken now, but that only becomes clear when the value of the seminars is defined. That ultimately ends in a discussion of the gospel use of methods and techniques and, if you remember, I am a little confused in my thinking on that subject at the moment.

I believe the seminars were instrumental in confronting the G.E. church community with the gospel, giving them a biblical self-image as a group, and providing the beginings of some practical skills that would help them reach out to others with the gospel. For a church group like ours (theologically and culturally) you started in the right place and laid the only foundation that is worth building on. 
If I were you and Glen Ellyn was my church I would be expecting the seminars (and sermons) to present and facilitate the acceptance of the gospel by the church members. I would expect that they would then move the church into a position to fulfill the gospel commission.

This is where my thinking is most confused. We live in a very non-participating culture. Even after the gospel enters a church, do we need to be led into its practical application or will each member begin to apply it spontaneously to their own lives? Probably both. Would a "gospel practicum" be the best plan for year three if you ever get to stay in a church that long?

The gospel movement in our church seems to have been started by Bible scholarship. Right now it seems that those embracing it are those who are willing to do the most studying and are open to change. But eventually, I'm thinking, maybe there will need to be some gospel pastors who teach people methods judged by the gospel. That would mean gospel evangelistic series, gospel 5-Day Plans, cooking schools, gospel ways of getting decisions, gospel visitation.

As I see it, your seminars are the closest thing to this right now because you are taking the gospel and trying to get its principles functioning at the local church level.

Here's the direction I'm coming from-in our local church people have to find ways of reaching out with the gospel, using gospel motivation and techniques. If they do this it will, of course, strengthen their experience in the gospel and fulfill the gospel commission. It will protect them, if they have this experience, when a new pastor comes who doesn't understand the gospel, with programs and techniques that miss the mark.

The idea here expressed of a "gospel practicum" was picked

up. An ongoing series of seminars was commenced in which real-life situations were enacted in a role play, followed by a discussion of effective ways to perform a ministry of reconciliation in those circumstances.

For those who wanted to develop specific skills in holding Bible studies and bringing people to the point of decision, plans were laid for the Lake Union Soul Winning Institute to come in and hold their lay-training program in the Fall of 1981. That would provide the members opportunity to combine the principles of this project with the skills of actually giving Bible studies. 
QUESTION $V$ What is your evaluation of the Sabbath afternoon seminars? Which ones would you rate as most helpful, and which would you rate as least helpful? Why?

Most evaulations of the seminars lay in the area of tech-

niques employed. Several found that filling in blank spaces in a participation manual from information displayed by an overhead projector was distracting from the flow of thought. Others felt the seminars were too structured and the information too centered, preferring more time for interaction and discussion in small groups.

Valid criticisms of the overall series of seminars pointed out that they were mainly preliminary in nature. They tended to set the groundwork for "practical" applications to follow. These sentiments were pointedly expressed by one participant who said:

These seminars have been valuable to me and to others I'm sure, but I feel they have been strong on lecture and short on practice. I happen to be geared to learning by doing, but I don't think I am entirely unique. Over the years I have seen the "penny drop," as it were, after a "hands on" experience.

Helpful for what? For inspiration yes, for works-perhaps not enough. There seems to be very little said about how to do works that result from being saved, and very little is said about how the observer, be he pastor or layman, "judges" when a person is doing which kind of effort in behalf of God's plans for this world.

I think you are prepared for the next step, which is, "Now that we have come this far this is how we will share with others."

Another said:

There are topics I'd like to see for future seminars; they have mainly to do with the practical aspects of sharing the gospel, and letting someone know that they are accepted while at the same time letting them know that there is a right and wrong (for instance, how do I deal with my co-worker who is living with her boyfriend?). How do you tell someone that, just because they've rejected something (i.e., the gospel) it does not become invalid? 
On the other hand, one person specifically mentioned that the real

value of the seminars was just the motivating power of their content, especially in their ability to integrate overall themes into clear capsules.

I found the seminars that were like in-depth sermons most enlightening-the putting together of individual factual tidbits into a well-designed fabric to see the whole tapestry. For instance, especially numbers $2,3, \& 7$ helped me to better understand primitive Christianity in all its simplicity.

Several people emphasized the side benefits of the seminars as a way of developing and experiencing Biblical koinonia.

The first gift of Christ that thrilled me through, that is the one that first got through to my soul, was that heaven was a place where one would be understood, where love and kindness were the mediums of exchange.

So Glen Ellyn, in the context of the seminars, has been this. We have focussed best our "togetherness" around the lofty themes of scripture. I like it. Whether the same seminar material would have that effect in a big audience I can't say. Your thoughts and your organization gave us the attraction we needed to come together the way we did. They helped us to know each other because they frustrated us to think. They were not lectures only but social experiences. Thanks, they were good times.

The seminars which received consistent mention as being most helpful were: "Justification by Faith Alone," "The Nature of the Church," "The Laity and the Clergy," and "Spiritual Gifts". The seminar that ranked least helpful by most was the one on "Worship". Several found the vigorous interaction demonstrated in writing up the church mandate and specific goals hard to handle, but felt the end product was worth it.

By the Author

To any person who may wish to run a similar series of seminars the following guidelines are reconmended:

(a) Do not spend an undue period of time on instruction 
(b) Do not cram too much material into each seminar. It is better to let a subject spill over into two seminars than overpack one.

(c) Allow more time for discussion groups and community participation.

(d) While it is important to encourage free interchange in the seminars, it is also important not to let one or two individuals dominate the conversation or lead the seminar in an unprofitable direction.

(e) It is very helpful to keep a balance between purely theological topics and practically oriented topics.

By the Author

From a realistic point of view it became evident that not everyone in the church grasped fully the theology of reconciliation. Nor was there a mass apprehension of the concepts presented among those who did eventually understand. The theological ideas opened to minds slowly and individually in the counterplay of events in parish life. The Sabbath morning sermons appeared to have the most formative influence on grasping the project's underlying theology and comprised its main focus.

The vicissitudes of life for each individual were next in importance on influence, providing golden opportunities to bring the implications of this theology home to each person. These opportunities were always maximized and took the form of marriage conflicts, mental/emotional stresses, dissolution of engagements, loneliness, sickness, death, and financial straitness. It was found that an understanding of the Biblical concept of reconciliation brought an experiential stability to over half of the parish members, and provided a matrix from which they could relate constructively to these existential crises that came their way. 
It was noted that those who did not seem to understand, or even rejected the principle of the project, were less able to handle crises and more prone to guilt, worry, anxiety, tension, and alienation.

One such person rigidly resisted experimenting with any new forms of community life, withdrew from the seminars, and although hanging onto a relationship with Christ as she understood it, was critical and intolerant of anything that wasn't accepted, conservative, traditional practice. Her personal life was marked by a high level of tension and heaviness of spirit, and on the occasion of a great tragedy in her family, found herself unable to share feelings of grief and anguish with other members. She chose to keep these feelings to herself, and her whole demeanor lacked that of joy or assurance.

Another person, after initially seeming to enter into the experience of koinonia, eventually withdrew when his personal life goals did not eventuate. He appeared to make his presence in the group dependent on an unconditional acceptance of all of his actions, as well as himself as a person, and had great difficulty in personal relationships because of this. Private conversations and the sixteen Personality Factor Tests revealed a deep insecurity, but the theology of reconciliation never seemed to open fully to his mind, with the result that questions of his non-acceptance with God always haunted him.

The main negative factor that emerged was a reaction that expressed itself in the minds of several members that Christian 
works and obedience did not play a role central enough in the project. Since the apostle Paul took the same high risk in preaching the gospel ${ }^{l}$ and was often similarly misunderstood as preaching a cheap grace, that reaction was to be expected from some and worth the risk. However, in order not to deliberately cause misunderstanding it was deemed wise in the future to clarify how koinonia and service are in fact the fruitage of the theology presented. Many of the church members found themselves better able to relate to the denominational crises presently facing the church. The seminar on Ellen White successfully explored one such crisis and that on justification another. The seminars on "The Nature of the Church" and "The Laity and the Clergy" appeared to help the members in exploring these crises by giving them a strong congregational orientation. This did not mean disloyalty to the denomination's administration, but it did mean a lessening of dependency on administration to motivate the church members to think and serve. Church members thought of themselves as more directly and personally related to God as individuals and as a community. They did not have to wait to be told what to do. The recurring theme of God's objective act of reconciliation and the seminar on "Justification by Faith Alone" as the framework of their assurance gave members grounding in that act rather than in the stability and success of the church. Whether or not people fully grasped the theology of the project, I feel that the community life of the church within the body of Christ

INoel Mason, "The High Risks of Preaching the Gospel," Australasian Record, November 17, 1975, p. 2. 
developed to a high level in the overall period.

The seminars provided a forum for the church members to enter into closer personal intimacies with each other than they had ever done before and to explore issues of a theological, practical, or personal nature that had been hitherto impossible in their church life. This was especially so in the seminar on spiritual gifts. Even though the seminars provided the matrix for koinonia to happen, it was on the theology presented primarily in the worship services on Sabbath morning that church members built and found their real fountain.

There is one sense in which I feel the koinonia developed had only an experimental nature and not a lasting nature. The church lacks a permanent long-term committed membership. Many of the members who are committed to Christ in a genuine and lasting way are transitory in their occupation or lifestyle, and in several years the actual church membership could be radically different. Most of the members are fairly scattered geographically, and this, together with the demands of modern living, makes it difficult to operate a mid-week fellowship meeting over an extended period. This meant that the church was forced to depend mainly on the Sabbath afternoon seminars for this experience. Even allowing for this, koinonia ran at a very high level.

The power of the koinonia developed among most of the members has had a powerful effect on my own life personally. It has been hard to leave this little group of people. Because of the openness of the group to experiment with new forms of community life, I was able to risk revealing my own humanity as a pastor and enter 
into more intimate relationships with this congregation that any other parish with which I have been associated. In every sense the risk was worthwhile and I have found the theology of koinonia and its unconditional acceptance to be beautifully validated. The effectiveness of the mission of the church was not readily apparent. The results of the Daniel seminars were statistically quite high, but baptisms were mostly among people who attended the program as a result of advertising rather than through the spiritual gifts exercised by church members. It appears that further thought and training needs to be given to exercising spiritual gifts so they become a functional part of the soul-winning program. 
CHAPTER V

\section{CONCLUSION}

I feel that this project has substantially supported the thesis that God's act of reconciliation constitutes a paradigm of ministry. It gave meaning, coherence, and productivity to my work and to the experience of the church at large. I can thoroughly 'recommend this type of project to anyone who is looking for a motivating and integrating framework in which to approach the tasks of ministry. In its theological base it is a stabilizing force that allows both the pastor and the members to cope with theological, personal, and community crises that come their way. During this program both came to see that despite the outcome of these crises, their personal reconciliation with God was not effected. Their security and frame of reference lay not in the vicissitudes of life but in a theological reality that no stress nor crisis could take away.

The quality of the life of the church in community increased significantly. Members were bound to one another in a supportive way and were able to deal with differences in a constructive manner. The extent of the apparent mission engaged in by the church members individually was a disappointing aspect of the project. It is true that time was needed to present and explore the concepts of the project and then to allow them to take root in experience, so 
it may well be that the fruitage in the form of actual growth in church membership will be seen in the years ahead. I had hoped that by the end of the project a greater gain in membership or attendance would have been evident. While it is true that we live in a nonparticipating society, it does seem that for church growth to take place on the basis of members' spiritual gifts, an optimum membership higher than that of Glen Ellyn is needed.

Suffice to say that the successful aspects of the project for me lay in experiencing the validity of reconciliation in areas of the individual's life and church in community.

I did, however, learn much about reconciliation personally in the course of the project. The purely academic research into the background theology of reconciliation made evident to me the ineffable depths and implications of God's great act of reconciliation to my life as a pastor. It enables me to rest in His unconditional acceptance of me even when I do not have many baptisms to present to Him at the end of the year. It enables me to relate in a constructive and healing way to those who point out that after all is done I am still an "unprofitable servant". And perhaps most of all it helps me to live with the ups and downs of my own psychological/ emotional frailties, knowing that I am not condemned, nor cast off, under any circumstances.

From a professional point of view it provided deep satisfaction to see this theological pattern of doing the tasks of ministry bring healing into the lives of individuals and into the church as a whole. 
It would be profitable to construct approaches to ministry on other theological bases such as "redemption" or "adoption" or "liberty". 
$\begin{array}{llllllllll}A & P & P & E & N & D & I & C & E & S\end{array}$

Reproduced with permission of the copyright owner. Further reproduction prohibited without permission. 

$\begin{array}{llllllll}A & P & P & E & N & D & I & X\end{array}$
A

1. Pictorial outline of the theology of the project

2. Tentative schedule of the project 
2 COT 5:10 - 6:10 THE COOD NEWS OF RECONCIIIATION AND ITS IYPLICATIONS

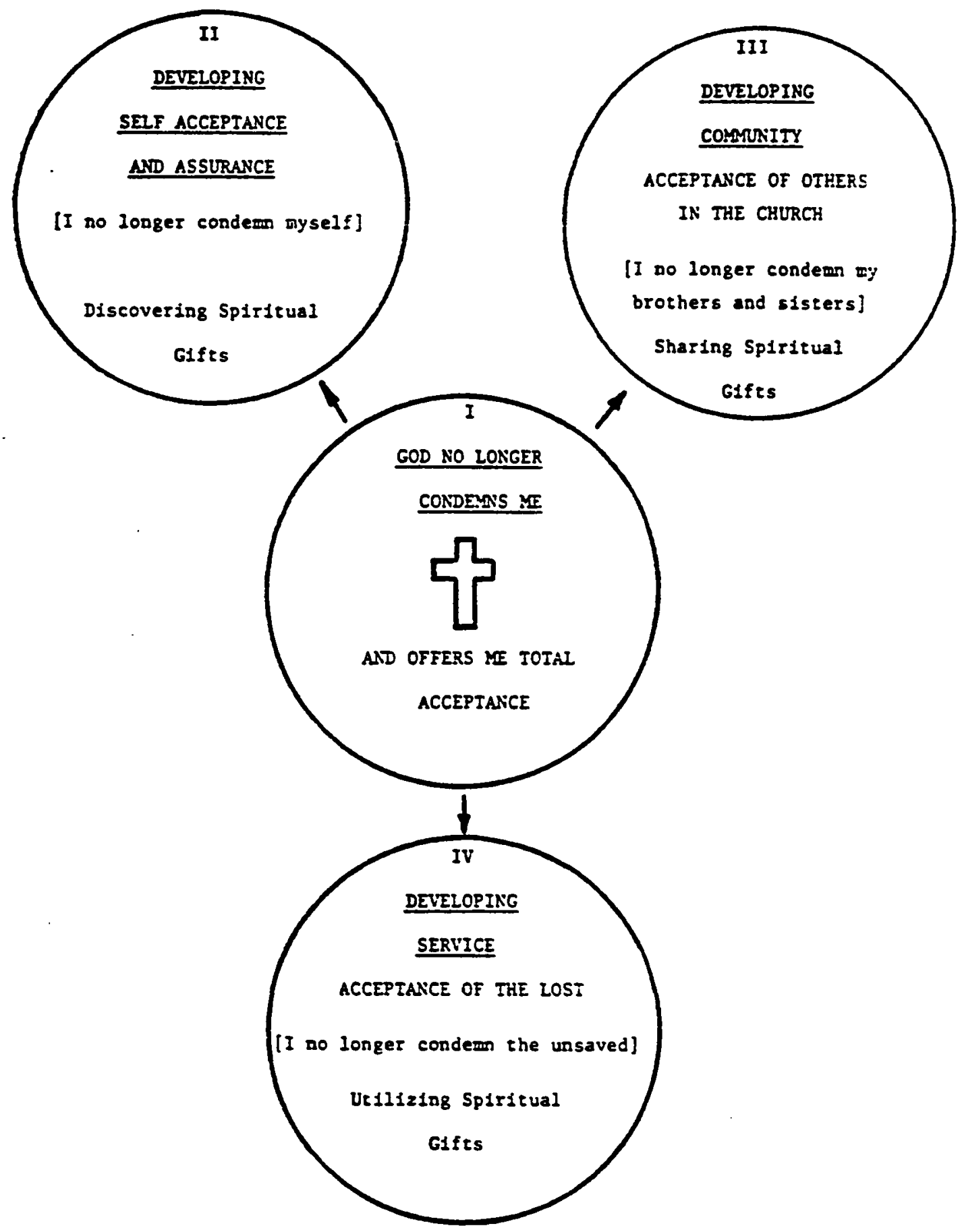

Fig. 1 Underlying theology of project 
Exhibit $A-2$
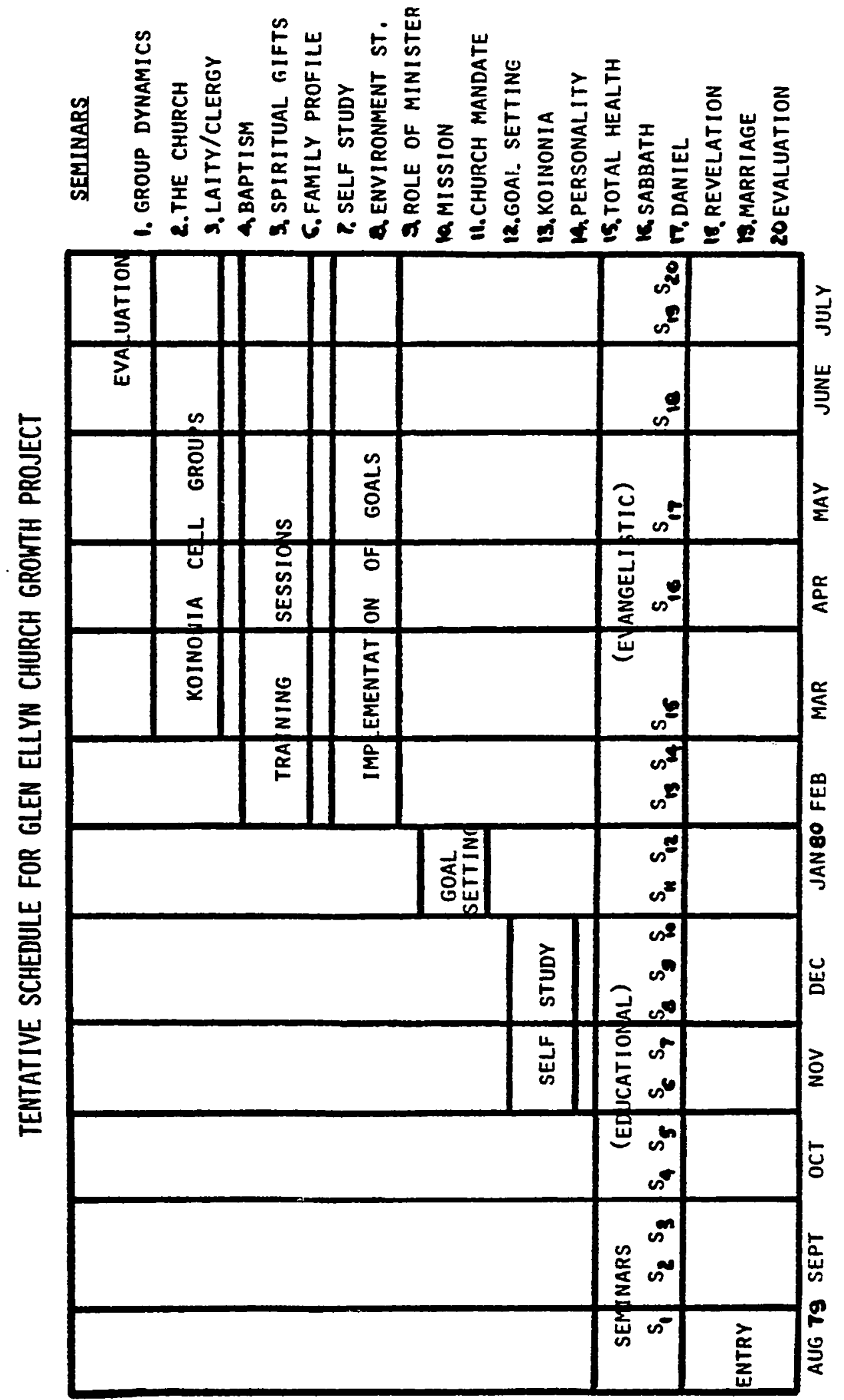

$\begin{array}{llllllllll}\text { A } & P & P & E & N & D & I & X & & B\end{array}$

1. Letter requesting participation in the evaluation

2. List of evaluation questions 
4014-2 Arthur Avenue Brookfield, Il. 60513

November, 1980

\section{Dear}

The last one and a half years have slipped by incredibly quickly and $I$ feel it is time to pause for a moment and take stock of what we have been doing in our Glen Ellyn Seventh-day Adventist Church and just how effective it has all been. For this reason I have attached an evaluation sheet that I would like you to fill out when you have some time to sit and quietly reflect on this period of our church life.

I want you to take this serlously. It will mean a lot to me to get your feedback. For this reason I have not given you an objective type of evaluation; rather I want you to write out your own thoughts honestly. Share what you feel have been the strong points and the weak points of our time together, and any suggestions as to how things could be improved.

To help you remember what we have been doing I have included a copy of the diagram I often use to sumarize the underlying theology of our church life, and a list of all the Sabbath afternoon seminars we have held. Then there are a few blank pages with questions at the top to which I would like you to respond. If you do not have enough space write on the back of the page or enclose extra pages yourself. Even if you have not attended all of the seminars please respond to as many questions as you are able.

Yours for a more effective ministry and in deep appreciation,

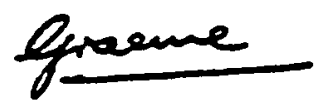

G. S. Loftus - Pastor

485-2385 
QUESTION I

Do you think you have a clearer mental understanding of God's act of reconciliation with the human race through the living and dying of Jesus than you did eighteen months ago? Share with me what your understanding is at this time.

\section{QUESTION II}

Has your understanding of God's act of reconciliation with us through the living and dying of Jesus made any significant difference to your own private way of living in the past eighteen months? Have you had any personal crises in your life during this time that you could risk sharing, specifically including how you dealt with them? Have you been able to deal with feelings of guilt, rejection or any other bad feelings about yourself? Have you developed both an assurance that you are at present in a saving relationship with God, as well as a sense of self acceptance? Have you discovered any spiritual gift He has given to you?

\section{QUESTION III}

Has your understanding of God's act of reconciliation through the living and dying of Jesus had any noticeable effect on your ability to experience reconciliation with other church or family members? Are you better able to accept others in the church or your family with whom you may have had open or unspoken conflict in the past? Are there any specific concrete examples you can give of this without necessarily disclosing names if you don't wish to? Do you feel that the koinonia (spiritual fellowship, sense of community) has increased in our church over the last eighteen months? In what ways?

\section{QUESTION IV}

Has your understanding of God's act of reconciliation through the living and dying of Jesus made any appreciable impact on both your attitudes toward and work for the unreconciled (the lost) over the last eighteen months? Can you share with me any specific examples where you have been able to use your spiritual gifts to minister to people? Can you give any specific examples of people you have been instrumental in leading to understand, accept and experience God's act of reconciliation? Are there any areas in ecology or society in which you have been able to effect reconciliation?

\section{QUESTION V}

What is your evaluation of the Sabbath afternoon seminars? Which ones would you rate as most helpful, and which would you rate as least helpful? Why? 
$\begin{array}{llllllllllllllllllll}A & P & P & E & N & D & I & X & & C\end{array}$ List of Sabbath sermons 
SABBATH SERMONS

DATE

July 28, 79 "Jesus Among the Candle-
Sticks" Rev 1

August 4

August 11

August 25

Sept. 1

Sept. 8

Sept. 15

Sept. 22

Sept. 29

oct. 6

Oct. 13

Oct. 20
"Reconciliation"

2 Cor 5:10-6:10

"Yahweh"

Exodus 6:2-8

"Baal Worship"

1 Kings 18:17-24

"Into a Far Country"

1 Cor 1:18-25

"The Great Pretender" Revelation 13

"Don't Underestimate the Church"

Ephesians 3:4-12

"Song of Solomon"

Song 5:2:10

"The Righteousness of God" I

Romans 3:19-31

"The Righteousness of God" II

Romans 3:19-31

"Job"

Revelation 3:14-22

"Nature of Sin"

Genesis $3: 1-15,21$
THEME

The one who has reconciled upholds church members and their ministers

Introductory outline of reconciliation and its implications

Reconciliation is the fulfillment of God's covenant

Counterfeit endeavors to experience reconciliation

The relationship between theology and culture

Satan seeks to imitate and re-enact the work of Christ and seeks to lead us to do likewise

The church vindicates God by reflecting His acceptance of men

Analogies of reconciliation

The objective nature of justification

Jesus our mercy seat

Repentance

The deep radical nature of $\sin$ in areas of relationship, behavior and inner nature 
DATE

oct. 27

Nov. 10

Nov. 17

Nov. 24

Dec. 8

Dec. 15

Dec. 22

Dec. 29

Jan. $5 \cdot 80$

Jan. 12

Jan. 19

Jan. 26

Feb. 2

Feb. 9
SUBJECI

THEME

Prayer

Forgiveness

"The Paralytid"
Luke 5:17-26

"Thinking with Sober Judgment"

Romans $12: 1-8$

"The UItimate Thanksgiving"

Revelation 15:1-8

"On Bums and

Billionaires"

Ephesians 1:15-23

"Our Second Greatest

Gift to the World"

Genesis 2:1-3

"The False Gospel of Tongues Speaking"

1 Cor 15:1-11

Ordinances

"This Is My Body"

Matthew 26:26-31

"For Those Who Despise

the Day of Small Things"

Zechariah $4: 1-14$

"The Two Witnesses"

Revelation 11:1-14

"The Model End Time

Sermon"

Acts 2:14-42

"What Shall Separate Us From the Love of God?"

Romans $8: 31-39$

"Mary \& Simon"

Luke $7: 36-50$

"Religion in the Dung Heap"

Philippians 3:1-9
The significance of spiritual gifts

Deliverance from the seven last plagues

Living in the two ages

Reconciliation as seen in the Sabbath

The dangers of subjectivism

How the Christian church has understood this expression through history

Drawing encouragement from the work of our advocate to face difficulties

God's act of reconciliation polarizes the world

The kerygma of the first apostles

The relationship of reconciliation to doctrine and lifestyle

Repentance

Paul's conversion 
Feb. 16

"Uncontrollable

Temptation"

Romans $6: 1-14$

Mar. 1

Mar. 8

Mar. 15

Mar. 22

Mar. 29

April 5

April 26

May 3

May 10

May 17

May 24

May 31

"Asking the Right Questions"

Genesis 2:15-17

"The Scroll and the

Lamb"

Revelation 4 \& 5

"The Near Kinsman"
"Death and Life"

Mark 14:32-38

"Annointing"

James 5:13-18

"Prayer"

Deuteronomy 7:6-9

"Second Advent Delay

in the New Testament"

2 Peter 3:3-10

Ordinances

"One Loaf"

1 Cor 11:23-33

"The Resurrection"

Matthew 28:1-15

"Earth's Last Message"

Revelation 14:6-12

"The Intimacy of Jesus" John 17

"The High Priest"

Hebrews 10:19-23

1 Peter 1:18-21

Applying reconciliation to severe crippling habit patterns such as homosexuality, depression, etc.

Greek and Hebrew thought on immortality

The role of the community in annointing

The function of prayer in maintaining a reconciled relationship

How the early church coped with the delay in the parousia

The role of the community of faith in the ordinances

The Lordship of Christ in our lives

God's act of reconciliation polarizes people

Reconciliation with God and men maintained by study, prayer and sharing

Understanding Christ's work of reconciliation through the old Testament High Priest

Justification by Faith Alone in the experience of Adam

Receiving our inheritance through redemption

The redemptive and avenging work of Christ 
DATE

SUBJECT

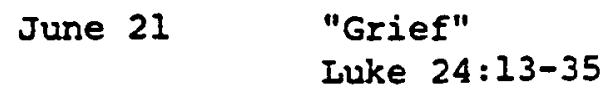

"Grief"

Iuke 24:13-35

"Knowing God" Deuteronomy 4:9-14

"Virgin Birth"

Matthew 1:18-25

"Total Health"

Matthew 19:16-22

"New Wine \& Old

Wineskins"

Acts 15:1-6

Ordinances

"God's Great Yes"

2 Corinthians 1

"Forgiven \& Forgiving"

Luke 18:9-14

"Cain and Abel"

Genesis 4:8-17

"Sovereignty and Goodness of God"

2 Peter 3:1-18

"The God Who Makes

'Old' New"

Hebrews 8

"Loneliness"

Ecclesiastes 4:7-12

"Water Into Wine"

John 2:1-11

"Dealing with Conflict" Isaiah 58:1-12

"Choosing an Elder"

Acts $6: 1-7$; Mark $2: 1-12$
THEME

Understanding the grieving process through the Emmaus experience

Propositional and experiential ways of knowing God and $\mathrm{His}$ work of reconciliation

The sinless nature of Christ

The relationship between reconciliation and health

The reasons why Judaism failed to understand reconciliation

The faithfulness of God

Learning to forgive

Security

The injustice and mercy of God seen in the Flood

The old and the new covenants

Coping with loneliness

The redemptive aspects of marriage

God's total unconditional acceptance of others helps us to do the same

The role of the community in ordination 
Nov. 15

Dec. 6

Dec. 13

Dec. 20

Dec. 27

Jan. $3 \cdot 81$

Jan. 10

Jan. 17

Jan. 24

Jan. 31

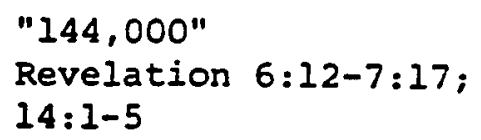

"Anguish and Joy" Luke 15:1-31

"The Scylla and Charbydis of Salvation" Galatians 5

"When God Laughed" Psalm 2

"The Voices of God" Psalm 19

"Christmas 80" Luke 1:26-38, 46-55; 2:25-35

"Jesus Our High Priest" I Hebrews $4: 14-16 ; 7: 23-28$

"Jesus Our High Priest"II John 5:19-30

"On Farmers, Vines and Grapes"

John $15: 1-8$

"The Trinity" Philippians 2:5-13; John 16:7-16

"Second Thoughts on Prayer"

Luke 11:1-11

Feb. 7
"Snakes \& Birth" John 3:1-21
Maintaining reconciliation until the end

The emotions of God in our acceptance or rejection of His act of reconciliation

The dangerous extremes of a law mentality and libertinism in the life of the reconciled

The sovereignty of God in adoption and judgment

God reveals Himself to us in nature and TORAH

Dealing with the death of a vision and hope as illustrated in the life of Mary

Christ's work of intercession

Christ's work of judgment

The necessity of maintaining our grasp of reconciliation

The relationship of the Father, Son and the Holy Spirit in the work of reconciliation

Prayer as a means of expressing our needs and maintaining our relationship with God

Reconciliation and the New Birth 
DATE

SUBJECT

Feb. 14

Feb. 21

Feb. 28

Mar. 14

Mar. 28

"On Grasshoppers and the Day of the Lord"

Acts $2: 14-21$

"The Man of Sin"

2 Thessalonians 2

"Heresy at Colossae"

colossians 2:13-23

"Forgiveness Unlimited"

Matthew 18:21-35

"Temptation"

Matthew 4:1-11

Apr. 4
"When I Am Old"

Psalm 71
THEME

"The Day of the Lord" in Joel

The nature and work of Antichrist

The sufficiency of Christ in reconciliation

Forgiveness enables men to forgive others

Christ was tempted to doubt God's word, actions and sufficiency

Reconciliation in old age 


\section{$\begin{array}{llllllllllllllll}A & P & P & E & N & D & I & X & & D\end{array}$ \\ Letter of invitation to participate in the Sixteen Personality Factor and Motivation Analysis Tests}


Glen Ellyn Seventh-day Adventist Church IN450 Main Street

Glen Ellyn, IL 60137

December 16, 1979

Dear Church Members:

Next Sunday morning 10ecember 241 at 10:00 a.m. in the church I am going to conduct the 16 Personality Factor Test and the Motivation Analysis Test for all those who want to avail themselves of this service. These tests are universally recognized as the most accurate and reliable personality tests available, and have helped thousands of church.members to understand themselves better and cope with the stresses of life more intelligently. I became qualified to administer these tests whilst at Andrews University and in my work as a chaplain, no other instrument I have come across opens up to you the profile of your character in such an accurate and helpful way. I would strongly urge you to come if you possibly can.

The tests will take about two and one half hours to complete, and will take a further two weeks to score and analyse. All results will be kept strictly confidential and handed back to you personally. It will be necessary for me to arrange a time with you after that when we can sit doun together and interpret the results. If you are married it will be doubly helpful to have your spouse take the test with you leven if he or she is not an Adventist), for your scores can be correlated and many helpful insights into how to make your marriage sweeter and happier can be gained. I will be able to give you strategies to implement in your life if there are any unpleasant traits you feel you want to change.

This service costs about $\$ 200$ from a regular psychologist. We would like to make it available to you free, but we have to make a change of \$10 per person to cover the cost of materials and computer scoring. I am sure you will agree, however, that this is minimal and well worth it once you have received the results.

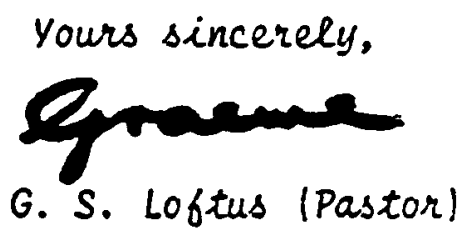




\section{$\begin{array}{lllllllllllllllllllll}A & P & P & E & N & D & I & X & & E\end{array}$ \\ Letters from a parishioner}

Reproduced with permission of the copyright owner. Further reproduction prohibited without permission. 
Exhibit E-1

\section{Elder Loftus:}

I need a favor from you, please. Please write out for me a paragraph on the completed work of Jesus for us. It's asking a lot to put so much in just a paragraph but I need something I can read quickly when I have become so discouraged that I don't even want to read or think anymore. I have become discouraged with the lack of progress and victory in my Christian life. I do believe that I have some small understanding of the plan of salvation but I am so manipulated by the "day to day" conflicts and the "here and now" problems that I lose sight of the vastly more important and eternal values. The serious thing about all this is that $I$ don't even have much of a desire to change because I have failed so many times it seems impossible. Only when the little problems pile up to the point where I consider suicide do I even have the courage to ask for help. Since you already know the worst about me I can't disillusion you further. Your sermons have been always a source of hope and encouragement so please, just a short sumnation that I can refer to when I don't have even the desire to search out for myself the food that I need. I can't go on very long expecting someone else to spoon feed me, but please just this once. 
The talk we had was helpful to me in that it clarified my position and strengthened my resolve to do what I already knew I should. You didn't really tell me anything I didn't know, but with my exceptional capacity for repeating the same stupid mistakes I need reassurance that God can forgive a chronic offender.

Probably my main hangup is - how can I be forgiven when I enjoy my sins enough to go back to them again and again. I realize that Christ suffered extreme mental agony by separation from the Father as well as extreme physical pain when He died for us. His whole life on earth He was misunderstood and unloved - and all this for me. Then I can't even make this love real enough to forgo some immediate pleasure for the great satisfaction (and peace) of conforming to His pattern for $m y$ life - even knowing as I do that God wants only the best for his children. It is just so difficult for me to grasp the reality of the concern of the Godhead for insignificant people. Especially for me since I have already a reasonably good knowledge of His will and believe that His way is without question the best way for us to live every aspect of our lives - and go on my own way. I've said the same thing 3 times now. From the way you talked to me that Sunday evening you already recognized part of my problem and gave me encouragement to deal with it. Thank you for your time.

I did sense at the end that you considered our talk somewhat of a failure (which is why I an writing this explanation). Toward the last I became very uneasy about my own less than complete honesty with you and I dropped in a rock that muddied up the stream a bit. Nevertheless. I want you to know that your time was not wasted. I did and do understand what you were telling me and appreciate your attitude of acceptance and concern.

Now I need to see and talk to you again when you have an hour or so to spare. Again thank you for everything. 


\section{$\begin{array}{llllllllllllllll}A & P & P & E & N & D & I & X & & F\end{array}$ \\ List of Sabbath afternoon seminars}

Reproduced with permission of the copyright owner. Further reproduction prohibited without permission. 
Exhibit $\mathbf{F}-1$

\section{LIST OF SABBATH AFTERNOON SEMINARS}

1. Sept 8 Group Dynamics \& Human Relationships

2. Sept 22 The Nature of the Church

3. Oct 6 The Laity \& the Clergy

4. Oct 20 Baptism, the Church and the Holy Spirit

5. Nov 3 understanding Spiritual Gifts

6. Nov 17 Discovering Your Spiritual Gift

6. Dec 8 Continued

7. Dec 22 The Role of Your Pastor

8. Jan 5 Mission

9. Jan 19 A Case Study of Mission in the S.E. California Conference

10. Feb 2 Establishing our Mandate For Existence (our Statement of Mission)

10. Feb 16 Continued

11. Mar 1 Examination of our Glen Ellyn Church Growth Patterns \& History, and the Characteristics of Its Surrounding Environment

12. Mar 22 Establishing Specific Goals

13. April 5 Koinonia

14. May 3 Caring For Persons: Skills in Helping

14. May 17 Continued

15. May 31 Justification By Faith Alone

16. June 28 The Journey of Faith (Stages in development of faith from childhood to maturity)

17. July 12 The Theology of Marriage

17. July 26 Continued

18. Aug 30 What Our Church Historians are Discovering About How the Spiritual Gift Given to Ellen White Actually Worked

19. Sept 13 The Sabbath and Justification By Faith Alone

20. Sept 27 Worship

20. Oct 18 Continued

20. Nov 15 Continued

21. Nov I Revision of Goals 
22. Nov 29 Practicum in Sharing the Gospel

23. Jan 10 How To Study the Bible

24. Jan 24 Prayer

25. Feb 7 Practicum in Sharing the Gospel

26. Feb 21 Understanding the Mid Life Crisis

27. April 4 Understanding Old Age 


\section{$\begin{array}{llllllllllllllllllllll}A & P & P & E & N & D & I & X & & G\end{array}$ Sample participation manual}

Reproduced with permission of the copyright owner. Further reproduction prohibited without permission. 
WELCOME to this Seminar on:

\section{JUSTIFICATION BY FAITH ALONE}

It was through a discovery of this truth that the apostle Paul shook the foundations of Rabbinical Judaism in the first century, and through its rediscovery that Martin Luther shattered the basis of Roman Catholicism in the sixteenth. "Justification by faith alone" has ever been the cornerstone of the Christian church. But because the Christian is ever "Prone to wander, prone to leave the God he loves"; because he has an inherent tendency to seek justification by some other means; it becomes constantly necessary to refocus his understanding of this great cardinal doctrine. A clear understanding of "Justification by faith alone" is the only thing that will release us as seventhday Adventists from the debilitating and spiritually exhausting bondage of perfectionism on the one hand, and bevitching snare of libertinism on the cther. It is the only thing that will truly motivate us to proclaim the eternal gospel to all those who dwell on the earth.

As you wait quictly for the seminar to begin pray that God will help us understand these important truths.

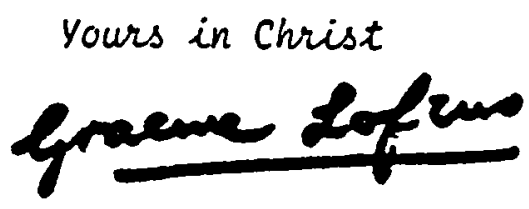

G. S. Loftus (Pastor) 
"JUSTIFICATION BY FAITH ALONE" AND PAUL

MET THE ERRORS OF
(1) HEATHEN GEMTILES

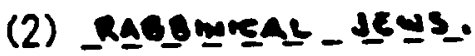

GENTILE - HEATHEN HORSHIP

REVEALS GQNSEIENSE - WAS ALIVE AND ACTIVE

EXISTENCE OF EUILI

SENSE OF GOD'S DISPLELSERE

EXPECTATION OF PUNISMMENT

STRUGGLE WITH LIFES SREAT_QUESTEOMS.

IHEIR GROUNDS OF HOPE

A. THE Ragallugy OF GOD

B. THE EFFICACY OF REPEMIAMES

C. THE MERIT OF PEESgMaL REETITUDE.

WORSHIP OF RABBINICAL JUDAISM

EVERY GOOD WORK IS MeriroRious

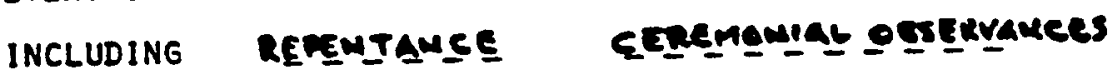

part surifise -

prayer gresumegron

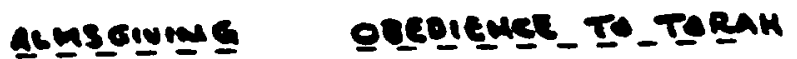

LQW SEPARATED FROM METLIAN

SIN EXPIATED BY SUPPEEIMS OR AETIONS_ OF SmMERS

GRAND ERROR - SELTE RIEKTEOUSMESS 
JUSTIFICATION IS A LEGAL- TERM

A golaknsic - EXPRESSION

TAKEN FROM A LAW_COURT_ IN THE SETTING OF JUDGMEMI -

SEEN FROM ITS

A) ARIITUETIC EXPRESSIONS (RON: 5:16; DEUT 25:1; PROV 17:15; OPPOSED TO comEeMnATYQN

Б) CORELATIVE_ - EXPRESSIONS (PS 143:2; GEN $18: 25 ; \operatorname{ROM} 2: 2$; ASSOCIATED WITH LUEOMEMI 1 Jn 2:1; PS $32: 1$ )

c) EQUIYALENI _ EXPRESSIONS (ROM 4:3,6-8;2 COR 5:19,21) EQUATED WITH ASUITTAL JUSTIFICATION MEANS THAT A BELIEVER HAS THE JUESMEMI _ YEROIEY _ OF "EIGHTEOUS _" RIGHT MOW.

JUSTIFICATIOH IS

A) AN $\triangle E$ _ OF GOD - HE QELARES _ US RIGHTEOUS (ROM 8:33; ISA 1:8)

B) A PRIVILEAE - OF CHRISTIANS - A. A CHANGE IN OUR RELATED WITH GOD (ROM 5:1, 8:1; Jn 5:24)

B. FULL MARLEN - OF SIN

C. RIGHT STANDIMG WITH GOD

D. ASSEPTAMEE_WITH GOD

E. IITLE - TO ETERNAL LIFE

JLSTIFICATION IS CONECTED WITH

A) SqaCE_ - THE SOMRE_ FROM WHICH IT IS QRENED (ROM $3: 24 ;$ EPH 1:7, 2:8)

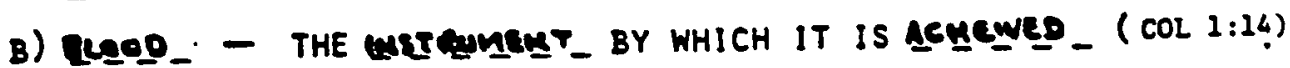

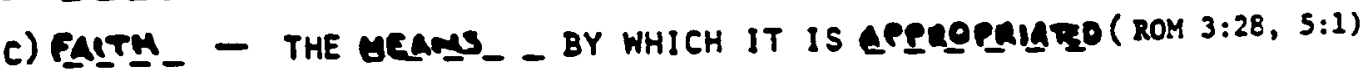

D) IELIEF - THE ERICET_WHICH FLOWS IUEM IT ( ROM 4:5)

E) WeQRES - THE EMOENEE BY WHICH IT IS ATIESTED_ (JAS 2:18,24; HEB 11:4-3: 
FAULTY VIENS OF JUSTIFICP.TION

JUSTIFICATION IS NOT UNDERSTOOD OR FULLY APPRECIATED WHEN

A) THE FUNCTION OF COD's LW - IS NOT UNDERSTOOD

B) THE DEEP RADICAL NATURE OF SIM _ IS NOT UNDERSTOOD

GOD'S LAH

A. EXPRESSES GOD'S PERFECTLY RIGUTEOUS EMARACTER _ (DEUT 33:2,3)

B. REVEALS GOD'S ETERNAL JuSTIEE _ _ A MLLMESS _ _ (ROH 3:26)

C. INCLUDES IMNER_ DROPENSIINE AND GOTIVES - AS WELL AS

QUIWARO_ EEYAYIOR _ _ ( PS 119:96; MATT 5:21,22,27,2E

D. OFFERS LIIE - TO THOSE WHO KEEP_ IT PERFECTLY ALL THEIR LIFE

(LK 10:28)

E. CONDEMMS - THOSE WHO SONT MEEP - IT PERFECTLY ALL THEIR LIFE

- GAI 3:10; JAS 2:10,11; ROM 1:18,2:13,10:

F. EXPOSES_- - MAN'S MORAL BANKRUPTCY (GAL 3:24; ROM 3:19,20)

G. FORMS THE GREAT STAMBMRD - IN THE WOSWEKT (REV 11:18,19)

SIN

INCLUDES A. DISTRUST - IN RELATIOMSMLP_(ROM 14:23)

B. pisogegremę _IN Bemavier _ _ ( 1 Jn 3:4)

C. EEPRAVIT_ IN MATURE_ (JER 17:9; PS 51:5)

REMAINS IN OUR NATURE ATTER - OUR JUSTIFICATION

DEFILES OUR RESI - AND MOST RELLEIOUS _ REPONSE ROM 7:18-8:1; GAL S:1;

REMOVED FROM OUR NATURE WHEN OUR EOQIES _ ARE

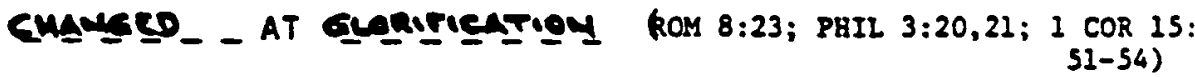


CHRIST AND THE LAW

CHRIST RUE MLLEE - THE ERECEPPS_ OF THE LAW IN HIS LIFE _ (GAL 4:4)

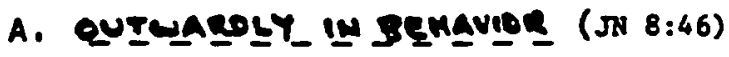

B. WWALOLY SM_MATURE - (LK 1:35)

CHRIST SAZISEIEO - THE REmaLTY - OF THE LAW IN HIS geatu GaI 3:13)

CHRIST BECAME OUR (A) EEPAESEMrATIVE - (ROM 5:18)

AND (B) SUBSTITUTE _ _ ( $(2 \cos 5: 14)$

(c) Loyocate _ (1 Jn 2:1)

JUSTIFICATION AND THE CROSS

JUSTIFYING RIGHTEOUSNESS IS (A) REQUIREO - IN THE LAW

(B) REYEALCO - IN THE gespę느 -

THE CROSS OF CHRIST REVEALS (A) IMYLEII8LE _JUSTIEE -

(B) LNFIITE - LEVE

GOD IS BOTH LUST. -

AND A dUSTIFIER -

FAITH

WE ARE NOT JUSTIFIED BECAUSE - OF OUR FAITH

FAITH IS DUAKENED - IN US AS KE BEHOLD

CHRIST'S LUITITYIIAS - FOR US ON THE CROSS

FAITH IS A GIFT - FROM GOD (PHIL 1:29; EPH 2:5)

FAITH IS THE MAMP WHICH GRASPS GOD'S JUSTIFICATION

THE CRES_ IS THE QMSEET - OF FAITH

FAITH IS THE QNEY _ MEANS BY WHICH WE ARE JUSTIFIED (ROM 3:28) 
THE HOLY SPIRIT
A. EMAELES US TO UMEERSTAND - CHRIST'S JUSTIFYING WORK
B. CONPIE IS_ US OF OUR nEES OF JUSTIFICATION ( Jn 16:8)
C. APPLIES - TO US THE SEEFITS - OF JUSTIFICATION
D. REEEMEEATES - US AT THE SAME TIME GOD JUSTIFIES US ( 1 COR $1: 2 ; 2$ COR $5: 17 ; \operatorname{COL} 2: 19)$
THO TYPES OF RIGHTECUSHESS IN THE BIBLE

\section{A. RIGHTEOUSNESS OF G๑D - ( ROM 3:21:26)}

THE RIGHTEOUSNESS UPON WHICH OUR JUSTIBIEATION - DEPENDS

oursoe _ us

THE MERIT OF A MERK.
B. RIGHTEOUSNESS OF ROM $9: 30-32)$

LIKE A MENSTRUAL CLOTH W'ITH RESPECT TO JUSTIFICATION

eMsiog _ US

WORKS

ARE IMPORTANT TO GOD BECAUSE THEY ARE

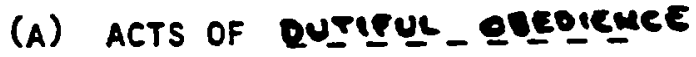
(B) AGREEABLE TO HIS REYEMLE WHL
(C) FRUITS OF THE gPIAIT -

HEB 13:15,16; ACTS 10:4; PHIL 4:18; 1 PET 2:5; HEB 6:10;

MATT 10:41,42; GAI 6:7,8; $2 \operatorname{COR} 9: 6 ; 1 \operatorname{COR} 3: 8,13-15)$

BIII THEY HAVE ASSOLYIEY NO NOLE IN OUR JUSTIFICATION

AT ANY TIME 
JUSTIFICATION

MARPEKS WHEN THE SINNER ACCEPTS BY FAITH THE VICARIOUS SUBSTITUTIONAR DEATH OF JESUS

THE WORK OF SEEYS.

GOD PECLARES - MAN RIGHTEOUS

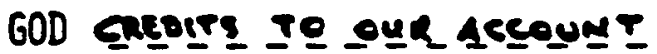
THE DOING AND DYING OF JESUS

QUYSIDE _ MAN

THE SINNER IS LQUITIED

QERFEET - AND SOMPLETE oucs _ren_all

THE Lasis - OF MAN'S ACCEPTANCE WITH GOD

OUR POSITION IN CHRIST

MUST BE MHSTMGUUISHED_ FROM SANCTIFICATION

RoOP - OF SANCTIFICATION

BLESSINGS OF SALVATION RQEGUMED
SANCTIFICATION

QEGIN S WHEN THE SINNER ACCEPTS BY FAITH THE VICARIOUS SUBSTITUTIONAR DEATH OF JESUS

THE WORK OF MELY_SPIRIT THROUGH THE YQRD.

GOD REGMIS IOMHEMAN RIGHTEOUS

HOLY SPIRIT LUEUYES - GRACE

INS 10E - MAN

SIN is susquge

imperrest AND SONTMUUIME oneonga

THE BESUET OF MAN'S ACCEPTANCE WITH GOD

OUR ERETISE_ IN CHRIST CAN NEVER BE SEMARATER - FROM JUSTIFICATION

EMEI _ OF JUSTIFICATION

BLESSINGS OF SALVATION APPLIEO - 


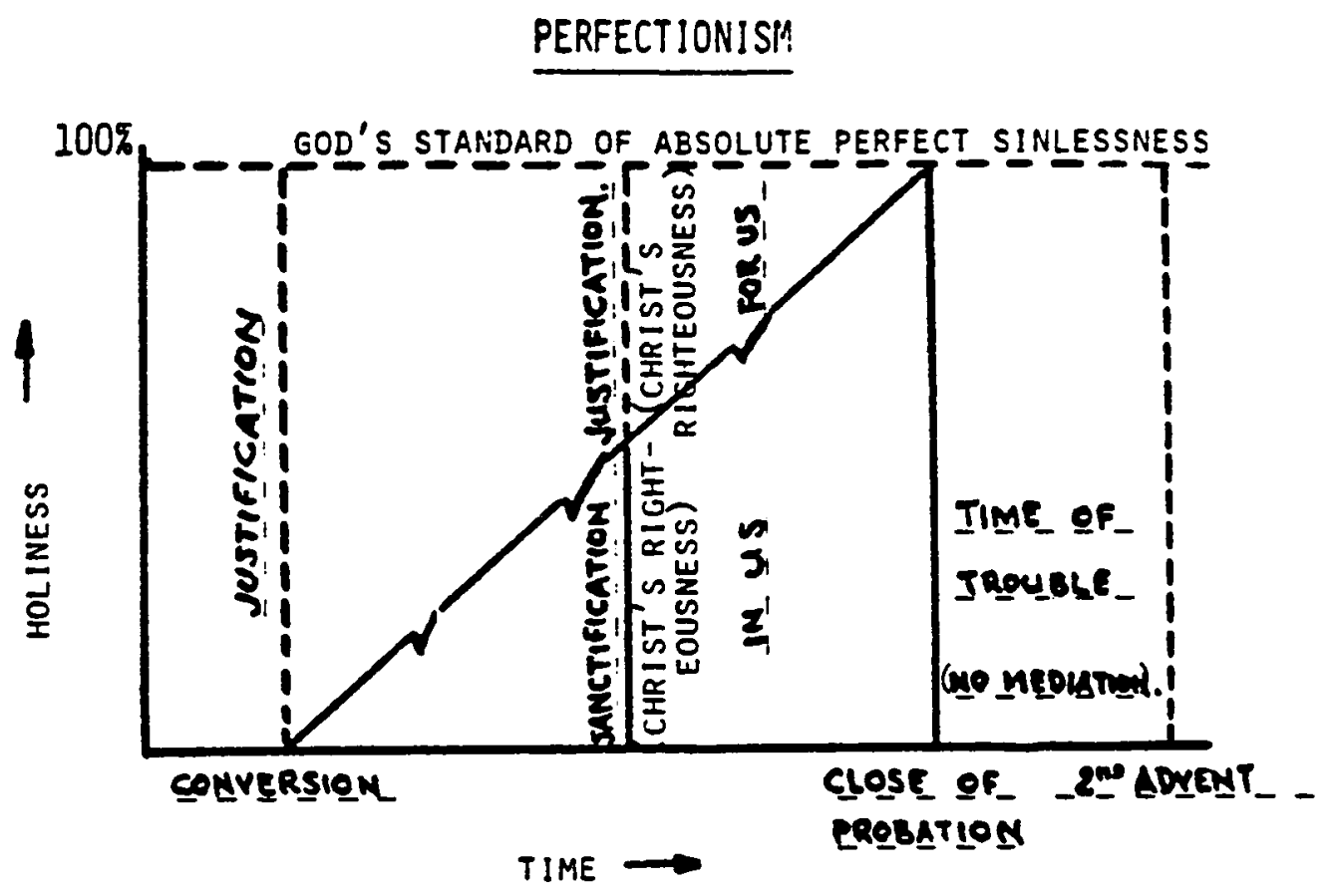

THE BIBLICAL PICTURE

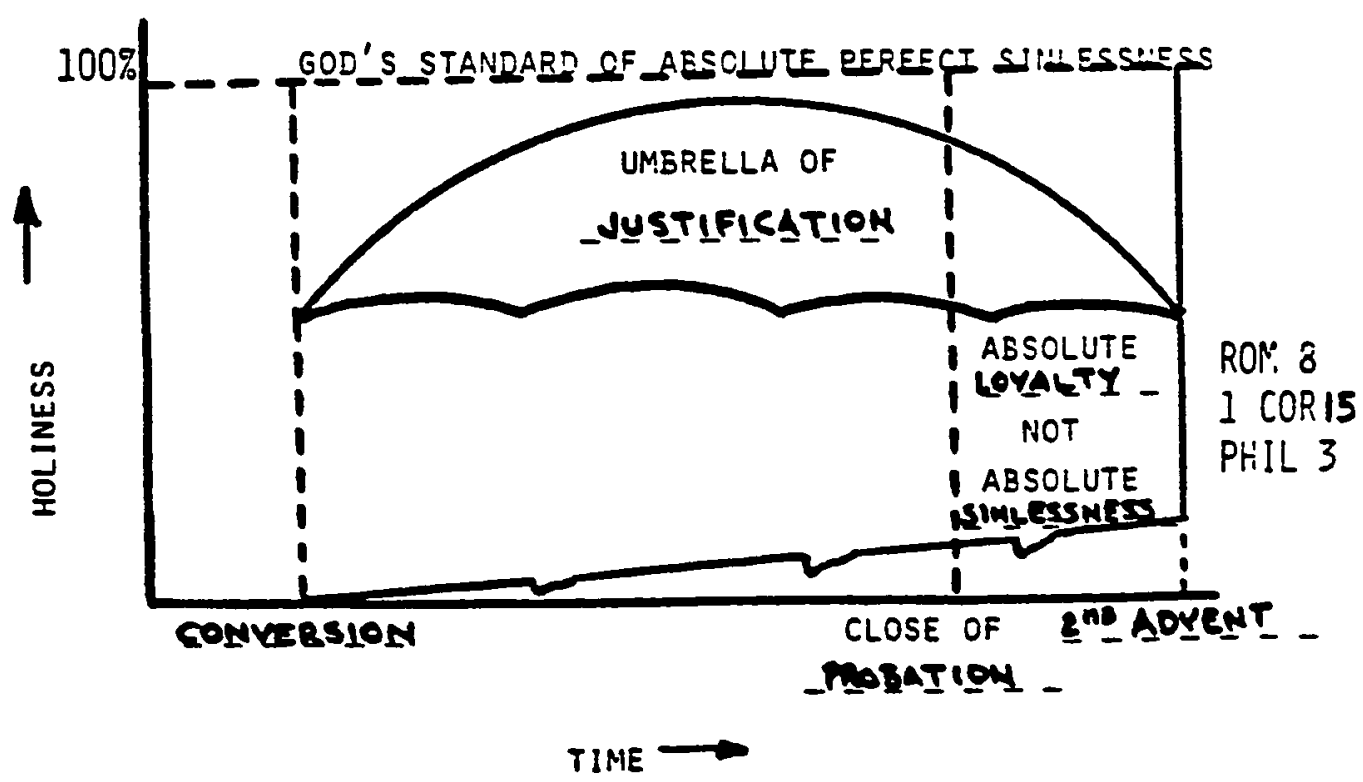




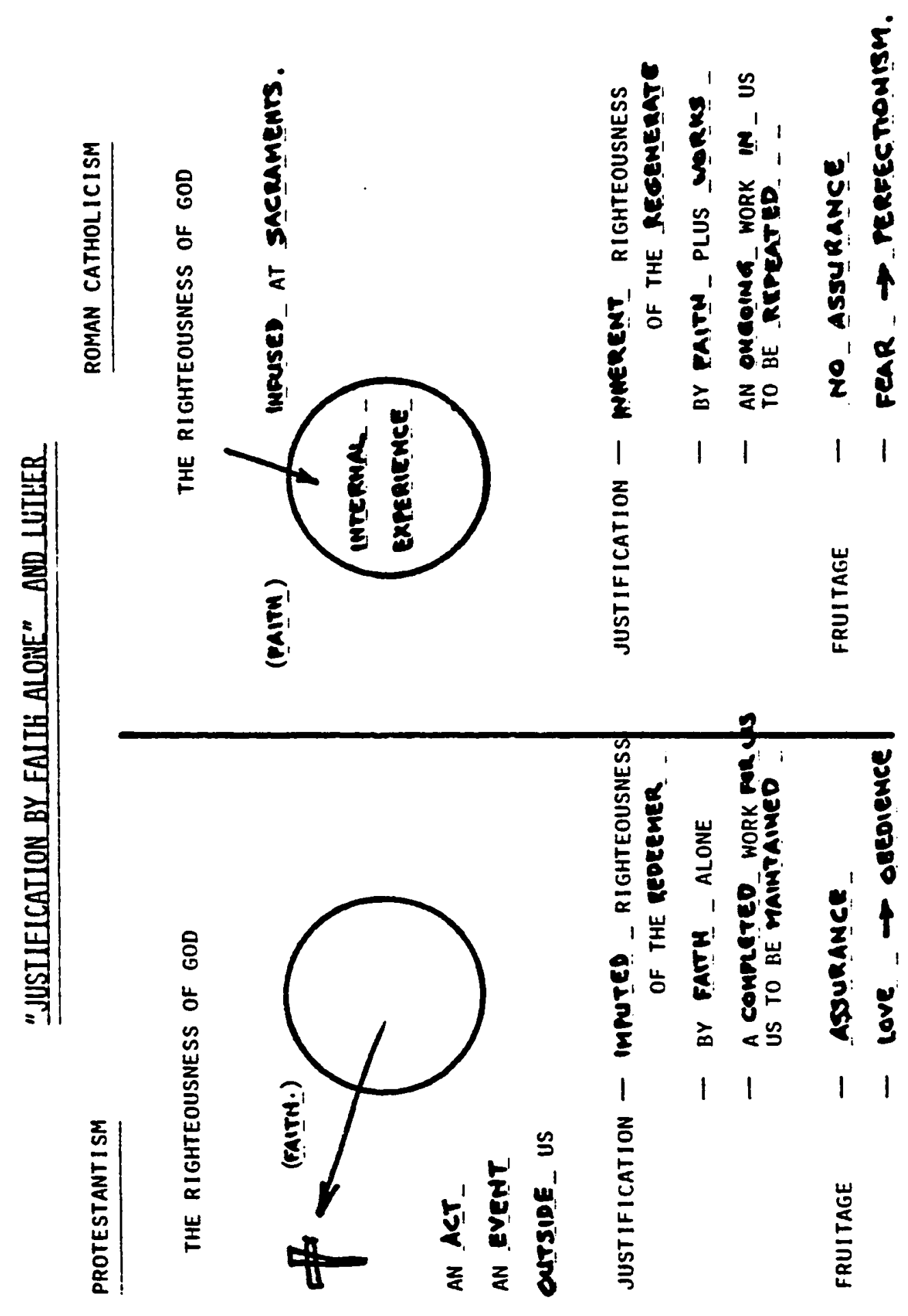


JUSTIFICATION AND THE JUDGMENT

THE CROSS WAS GOD'S

THE JUDGMENT IS

JUYYMENT - ON MAN

GOD FINALLY AND

AND HIS SIN

IRREVOCABLY

ROMPINE - HIS JUSTIFICATION

YESLARIME_ - MEN

JUSTIFIED

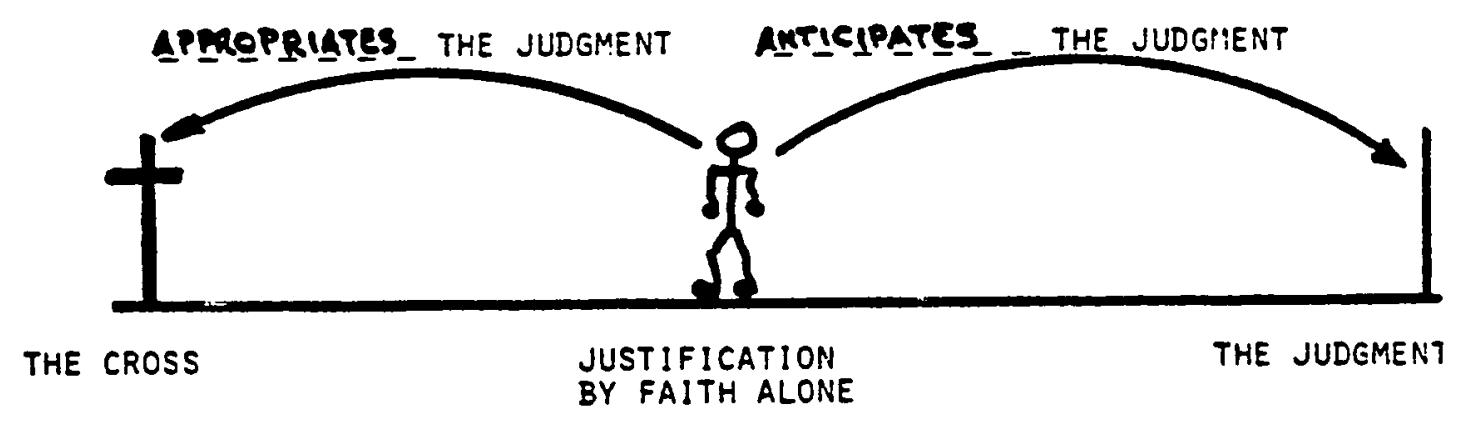



$\begin{array}{lllllllllllllll}A & P & P & E & N & D & I & X & & H\end{array}$

1. Letter to conference president requesting prioritizing of

ministerial duties

2. Priority Rating Sheet

3. Letter to community

4. Community priority rating sheet 
4014-2 Arthur Averie

Brookfield, II 50513

November 22,1979

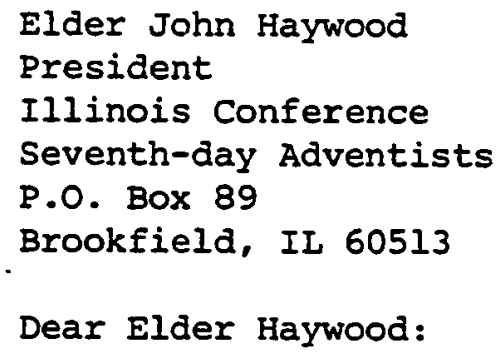

G. S. Ioftus 
Could you please rank the following 20 aspects of a minister's work in order of your considered importance, marking 1 for the most important, down to 20 for the least important.

Visiting Calling in the homes of members or at their place of work in a systematic program to meet each member as a pastor, and understand their life situation and provide pastoral care as needed.

Teaching Working directly with adults in religious education classes and/or special seminar series. e.g. teaching the Pastor's Bible Class, planning and/or teaching classes for Sabbarh School teachers, teaching in special short-term classes, etc.

Counseling with individuals in personal and spiritual crisis, with couples planning to be married, with young people on personal and vocational problems, with the sick, dying, and bereaved. Administration Administering the planning, organizing, and implementing of the work of the church, working with boards and committees as an executive, helping to plan the financial program of the church, coordinating activities to accomplish the mission and work of the church.

Evangelism, Public and Personal Holding meetings, calling on the unchurched people in the community, bearing witness to the Good News, calling on prospective new members, and training laymen to be evangelists.

Community Services Promoting church programs to benefit the people of the community. e.q. Civil Defense, Disaster Relief, Welfare, Health Education, Stop Smoking Plans, Nutrition Schools.

The Leader Serving as the recognized and acknowledged leader in the congregation--the person to whom members turn for advice and guidance on all aspects of the life and work of the congregation. Developing a Father image.

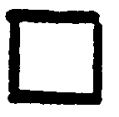

Denominational Responsibilities

Cooperating with departmental and Conference officials by presenting and carrying out denominational programs and campaigns in the local church, such as ingathering, magazine subscriptions, lay witnessing training. Enlisting denominational resources for use in the local situation.

Liturgist Planning and conducting aestheric and meaningful worship services, giving attention to finer details including aspects of music, communion services, funerals, weddings, infant dedications, etc. 
Enabler Helping others ident ify their own special call to service and ministry and enabling them to respond to that call through encouragement and training. Facilitating the discovery and development of spiritual gifts among the members.

Scholar Spending regular time developing a deeper knowledge of the Bible and related professional skills. Engaging in continuing education. Continually updating.

Spirituality Maintaining a regular, disciplined, personal devotional and prayer life. Serving as an example in moral and ethical character.

Preaching Spending adequate rime in sermon preparation. Delivering meaningful messages from the pulpit each Sabbath.

Children's Leader Seeking to win the children and youth of the church. Having a children's corner in the sermon. Active involvement with the school. Participating in JMs, Pathfinders, Campouts, etc.

Public Relations Becoming involved in civic and community affairs. Joining service organizations such as Rotary, the local minister's fraternal, etc. Representing the church in outside functions and through the media.

Social Activist Militarity working to regress social evils condemned by the Bible. Political lobbying. Working for civil rights.

Trouble Shooter Seeking to maintain harmony and resolve conflich among church members over personality clashes in church programs, finances, elections.

Secretary Efficiently oversees such office activities as church bulletins, correspondence, accurate records, prompt reporting to Conference officers and church constituency, compilation of statistics, etc.

Husband/Father Maintains a happy home. Spends time developing his marriage and relationship with his children.

Steward Leads financial drives and building programs. Promotes

reached. 
Exhibit $\mathrm{H}-3$

\section{BROADVIEW SEVENTH-DAY ADVENTIST CHURCH}

3101 South, 25th Avenue

Broadview, Illinois 60155

(Ares Code 312) 343.9484

Dear Friends in the Broadview Community:

I am the new Pastor of the Seventh-day Adventist Church on the corner of 25th Avenue and Erika St. near your home, and I would genulaely like to find out how best I can serve my community, as well as my church. I would certalnly appreciate it if you could take a few moments 50 complete the following questionnalre and I will call back tomorrow and collect It. Alternately, you could drop it into our mallbox which is over the road from the church.

Thanking you for your help.

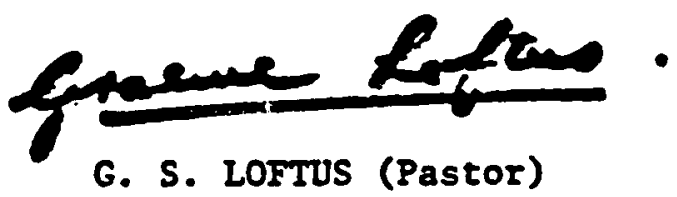

(Tel) 620-0568 
Exhibit $\mathrm{H}-4$

WHAT ARE YOUR PRIORITIES?

Could you please rank the following 7 aspects of a minister's work in his community in order of your considered importance, marking [1] for the most important down to 7$]$ for the least important.

Counselling - Serving the communty through the expertise of training in meeting personal crises such as marriage problems, depression, vocational guldance for youth, sickness, death, suicide, loneliness, child abuse, unwanted pregnancles.

$\square$
Community Services - Arranging programs on a regular basis to benefit the people of the comunity. Such as seminars on: (Please Indicate which)

Stop Smoking

Nutrition \& Cooking

Gardening

Heart Care

Welfare Needs

Managing Finances

Coping with Death \& Dying
Drug \& Alcohol Problems

Effective Parenting

Reeping Fit

Marriage Enrichment

Adjusting to Retirement and old Age

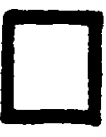

Child \& Youth Education - Organizing

Vacation Bible Schools

Weekly Bible Classes

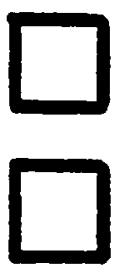

Soclal Activist - Militantly working to regress social evils, political lobbying, working for civil rights.

Preaching - Holding meetings for the community that help explain:

How to find meaning in life

How to find peace with God

What lies ahead in the future

How to cope with life's stresses

How to understand the Bible

Teaching - Making study guldes avallable that will enable you to study the Bible in your ow home and understand it better.

I do not think any of these services are necessary

P.S. If you have any suggestions please write them below. 


\section{$\begin{array}{llllllllll}A & P & P & E & N & D & I & X & & I\end{array}$ Statement of Mission}




\section{STATEMENT OF MISSION}

As we consider the depth of the atonement, the critical nearness of the second Advent and the origin of our local Seventh-day Adventist Church here in Glen Ellyn; we fully believe that God has providentially placed the church here in this district as part of the universal body of Christ to convey God's love to the world, and in response to Matt 28:18-20 urgently invite it to salvation in the following ways:

(1) By sustaining an experience of koinonia (spiritual fellowship) amongst our members, stemming from an estimate the cross places on each of us, and manifesting itself in genuine mutual unconditional acceptance, compittment, support and building up of one another.

(2) By proclaiming the claims of God's law and how the gospel meets those claims through justification by faith alone. We will do this through all the channels available to us; verbally, through the exercise of our individually bestowed unique spiritual gifts and through the changed lifestyle resulting from our acceptance of the gospel.

(3) By serving the physical, mental, emotional and spiritual needs of the local church, local community and world at large through our time, effort and money. 
$\begin{array}{llllllllll}\text { A } & P & P & E & \text { N } & D & I & X & & \text { J }\end{array}$

1. Chart of growth over 17 years

2. Chart of yearly rates of growth

3. Chart of gains and losses

4. Environmental statistics 
Exhibit J-1

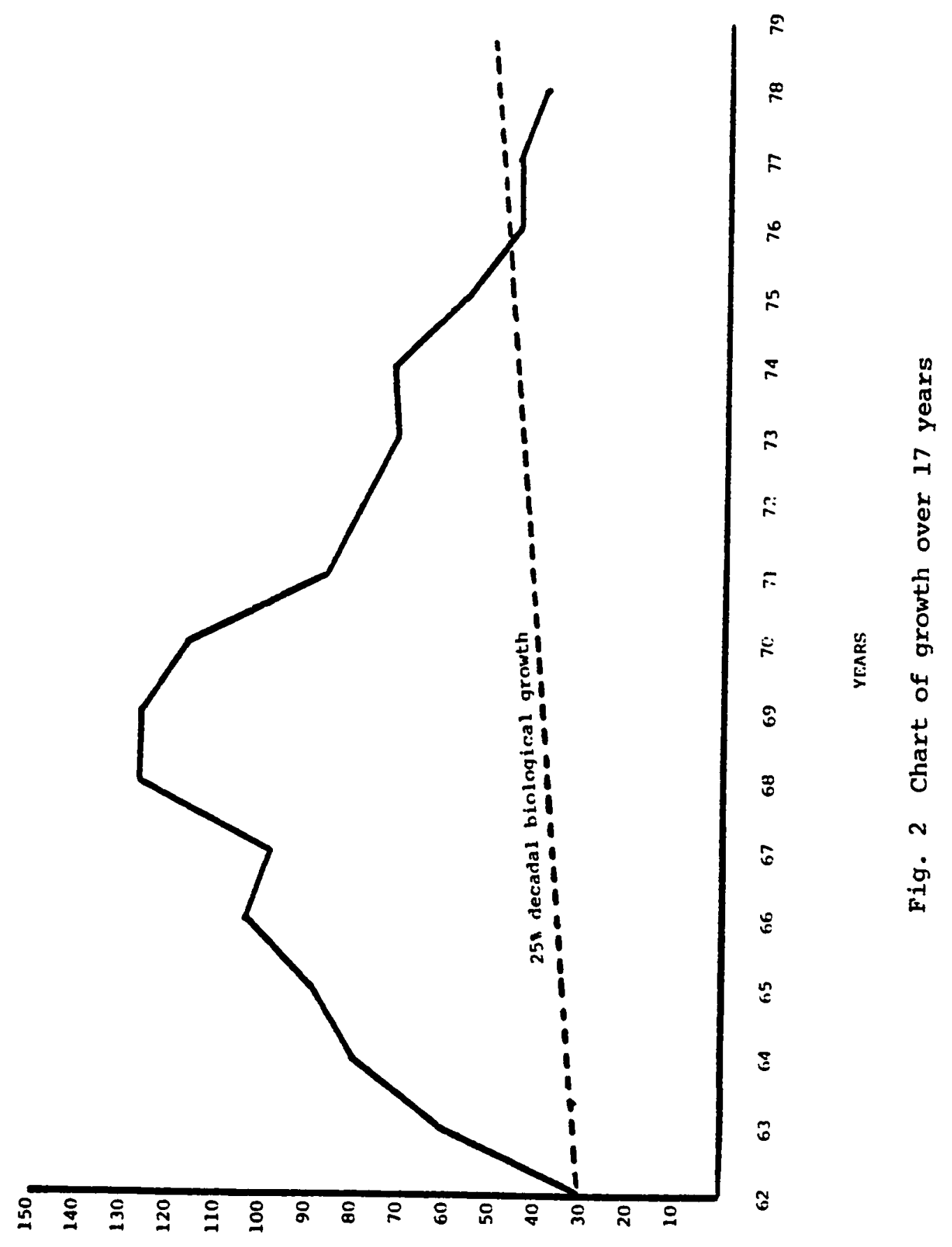

AIHSZ3EhรW 
Exhibit J-2

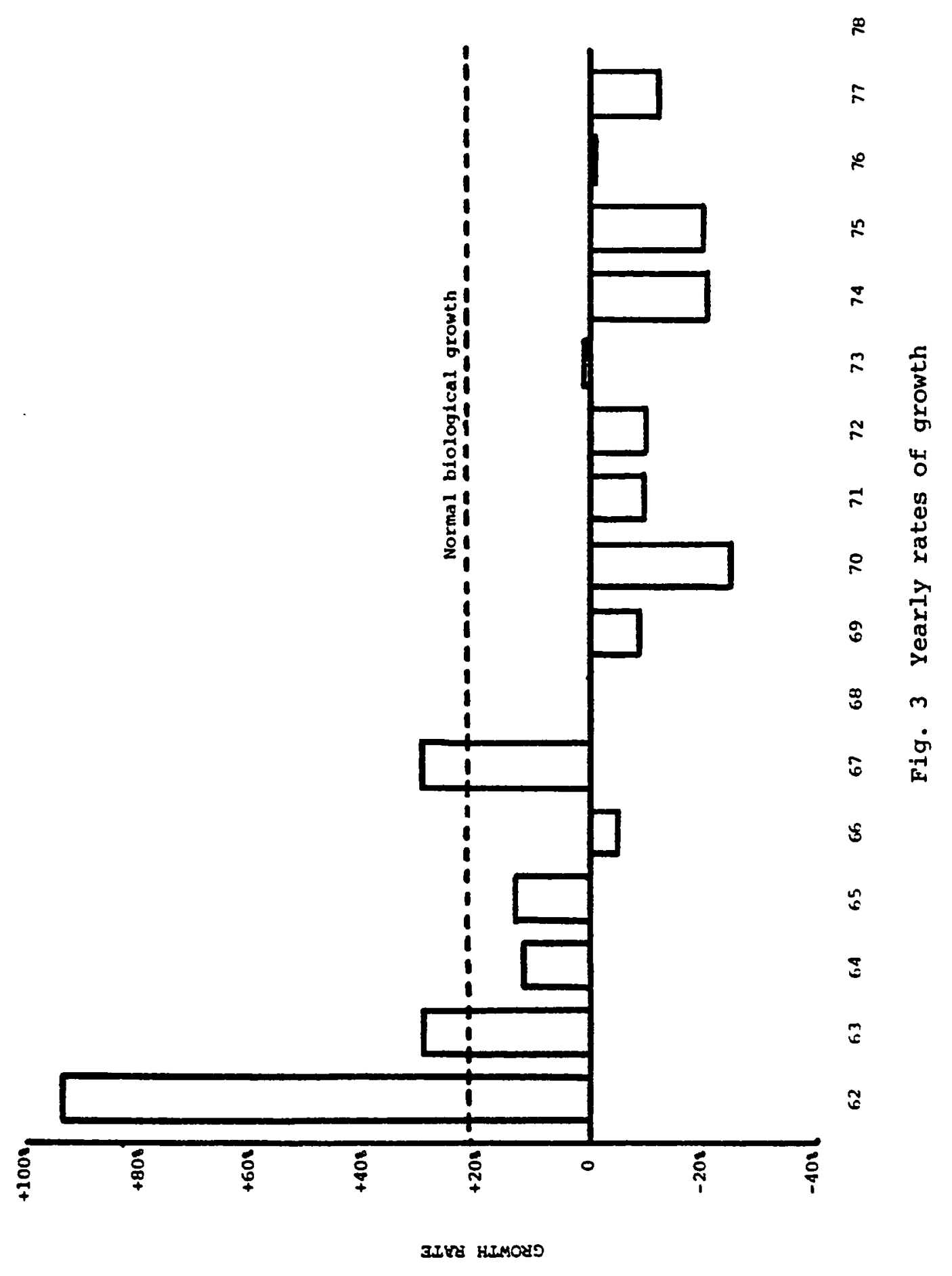


Exhibit J-3

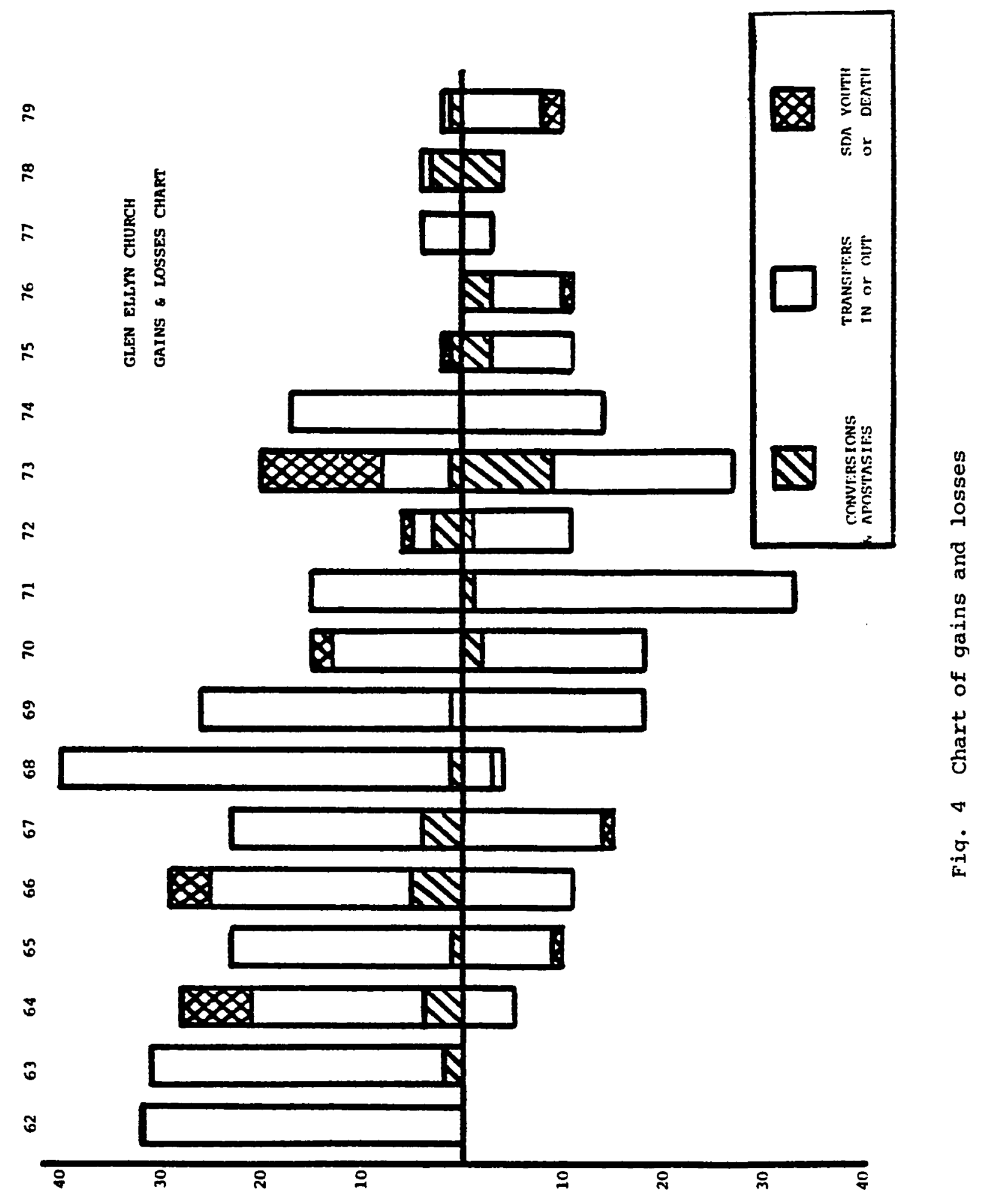




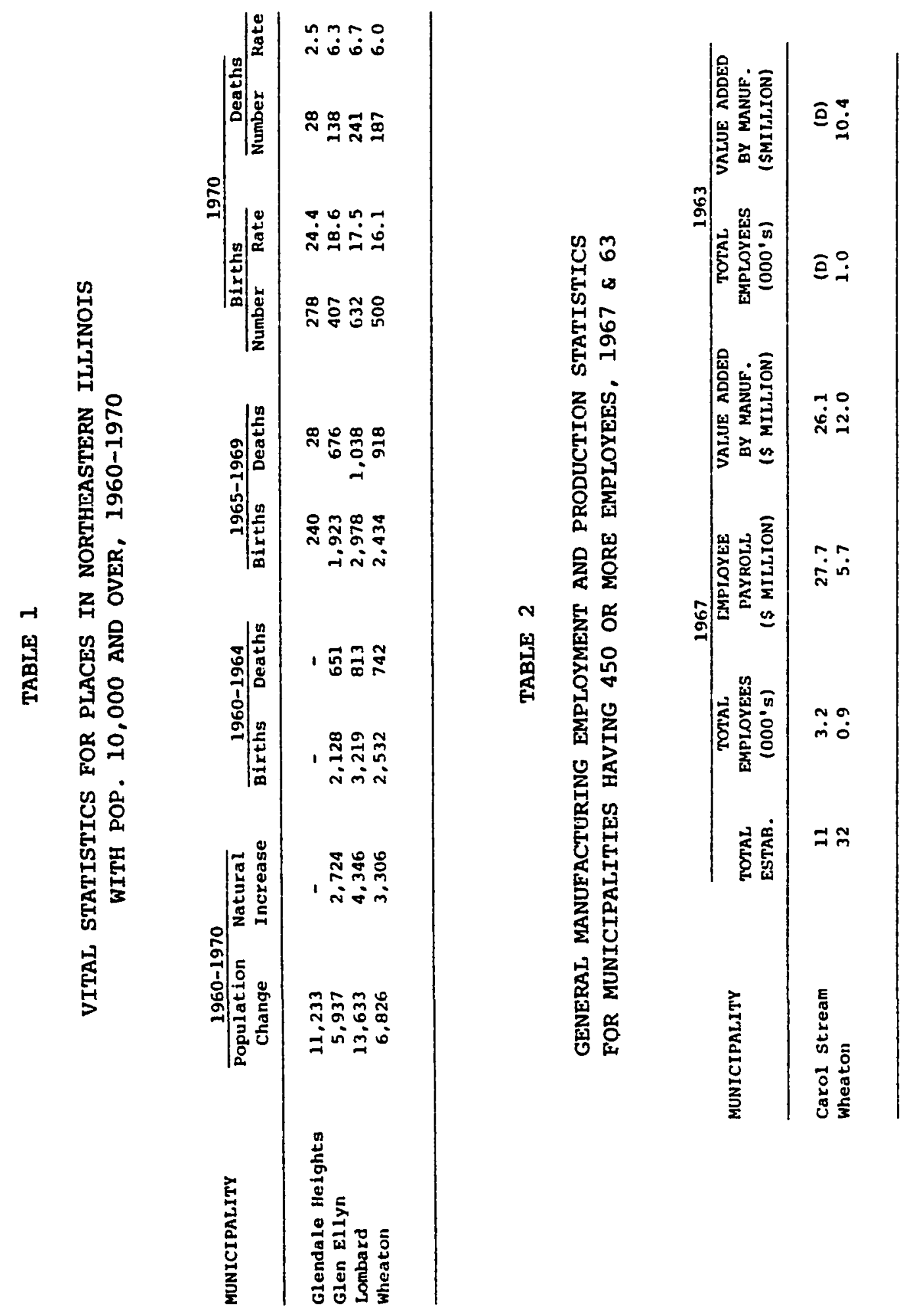



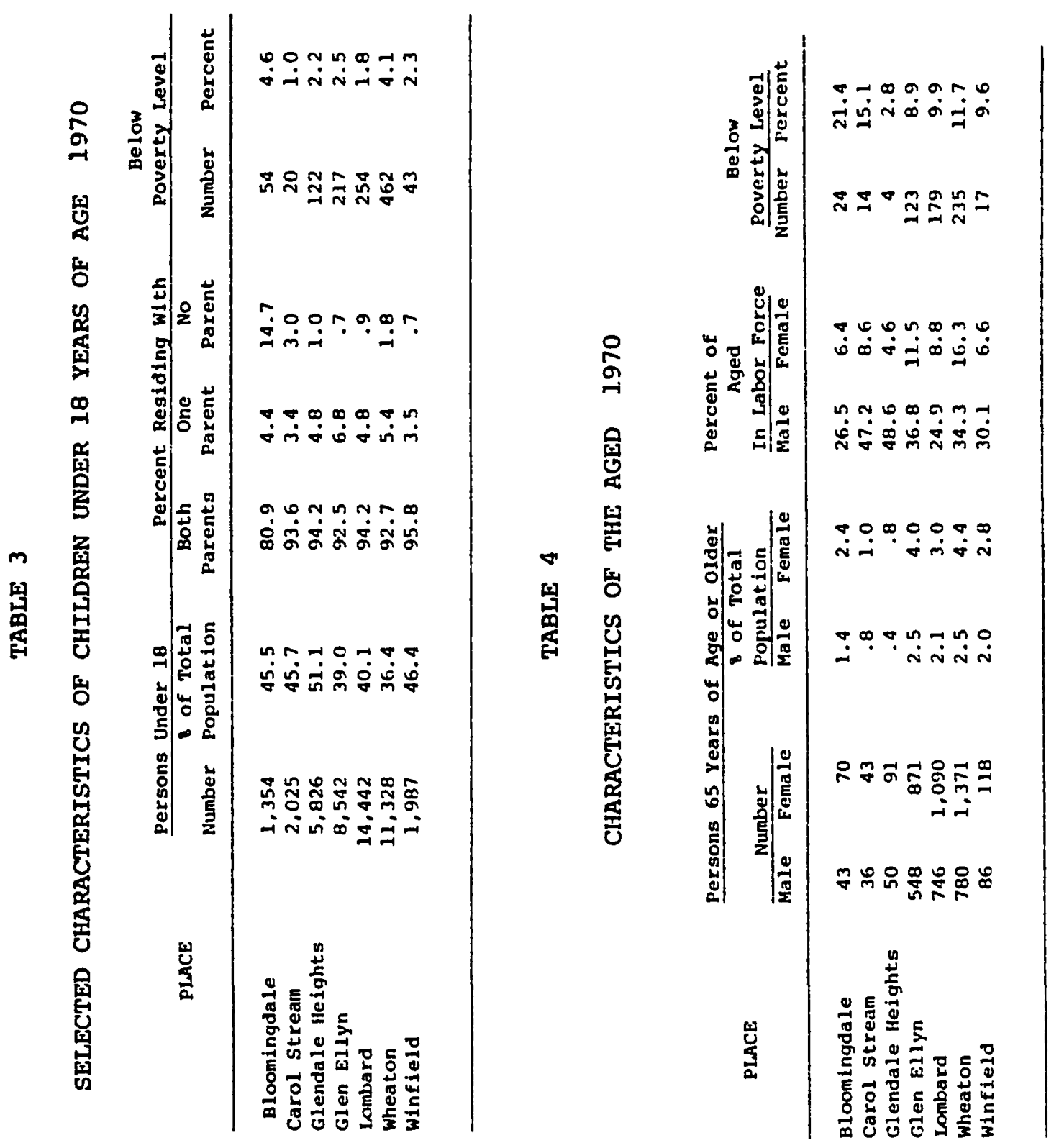

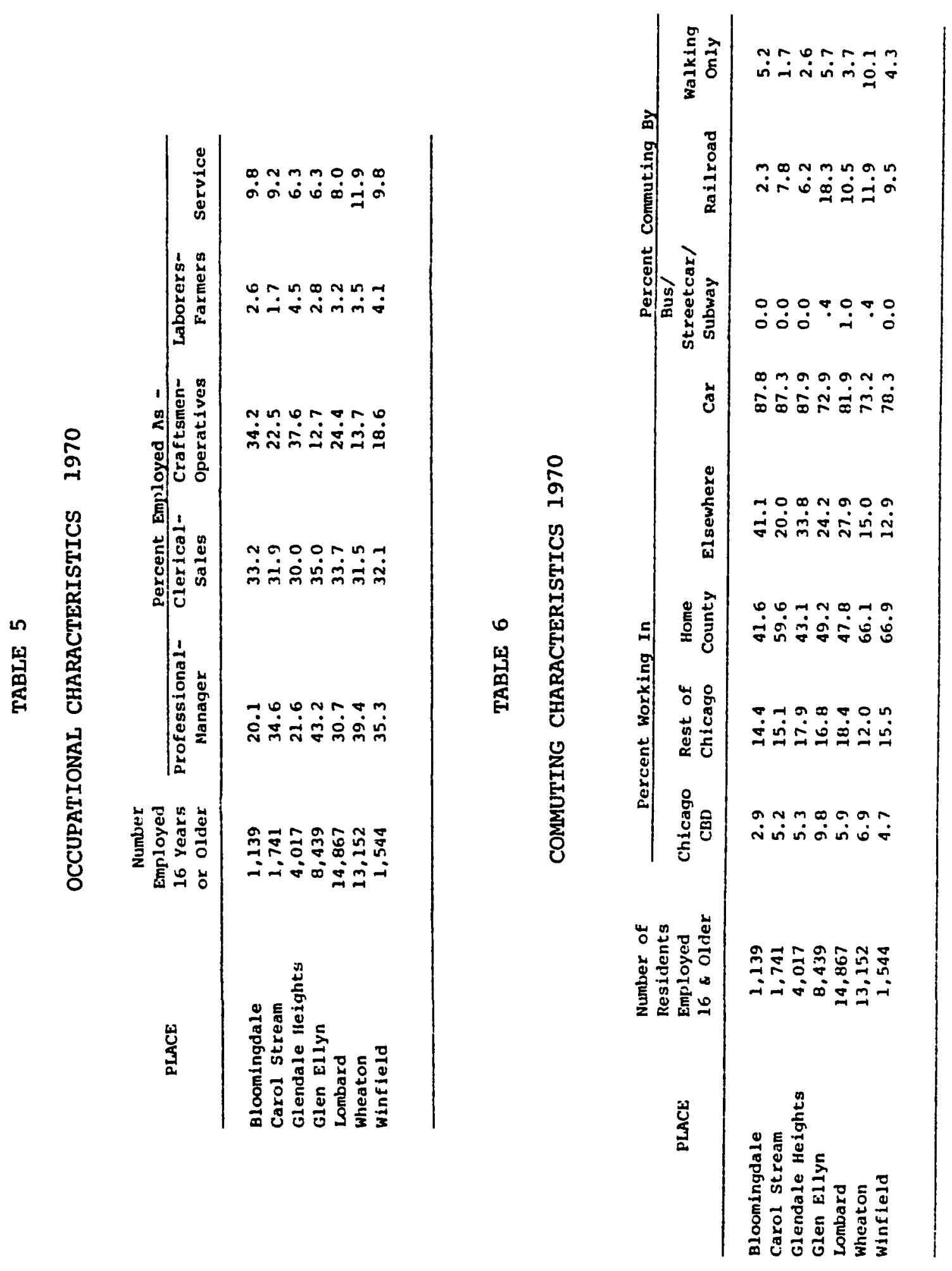

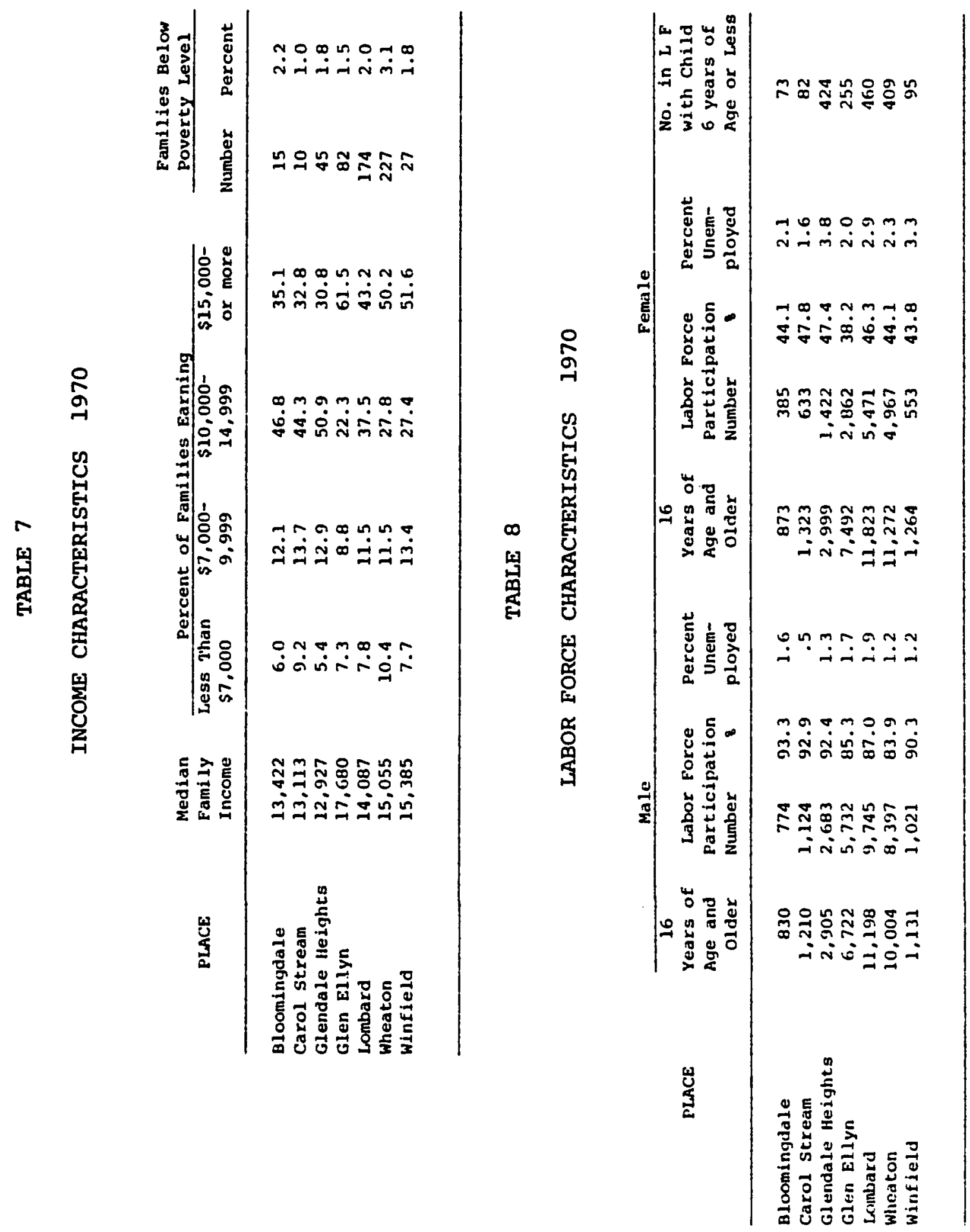

Reproduced with permission of the copyright owner. Further reproduction prohibited without permission. 

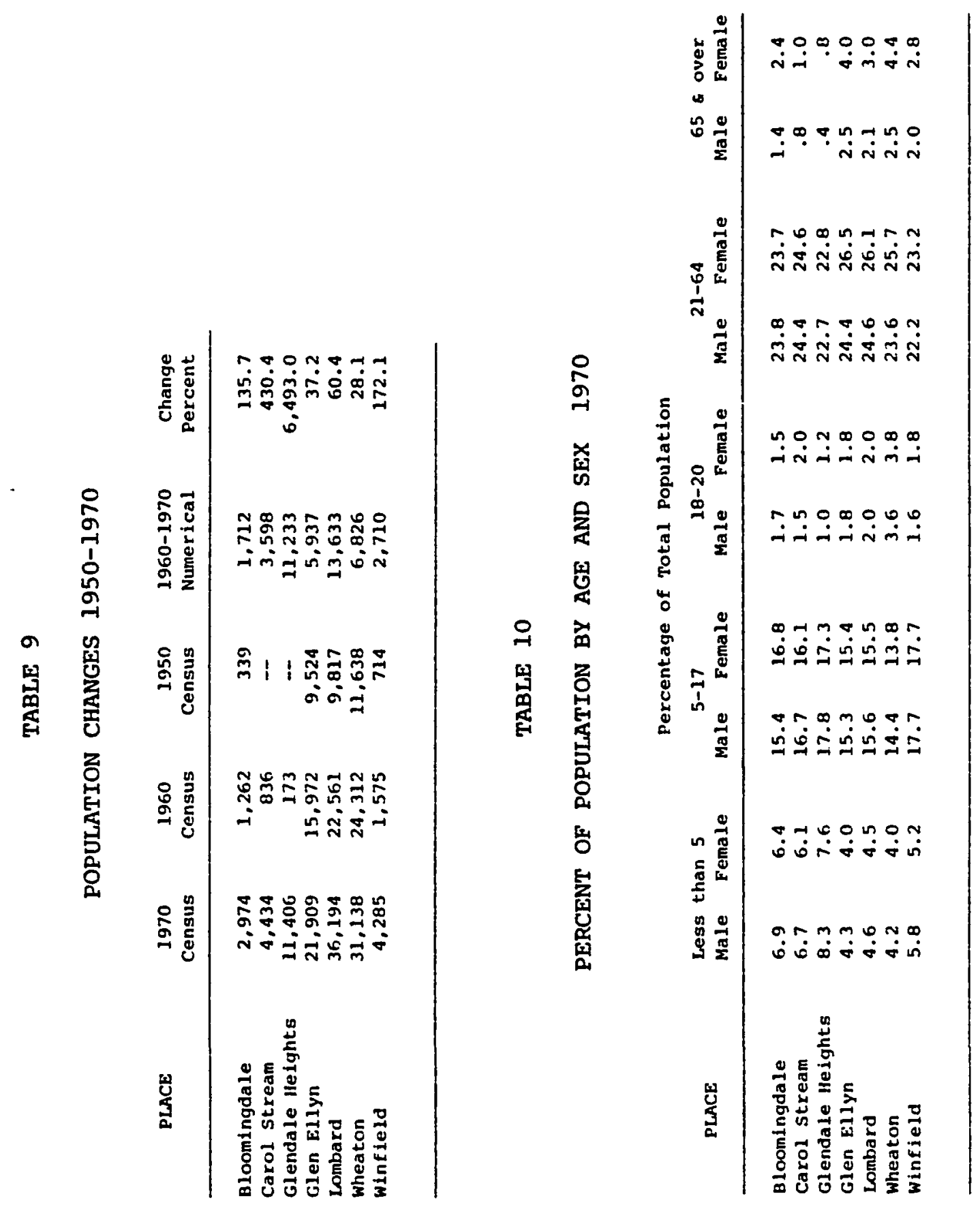

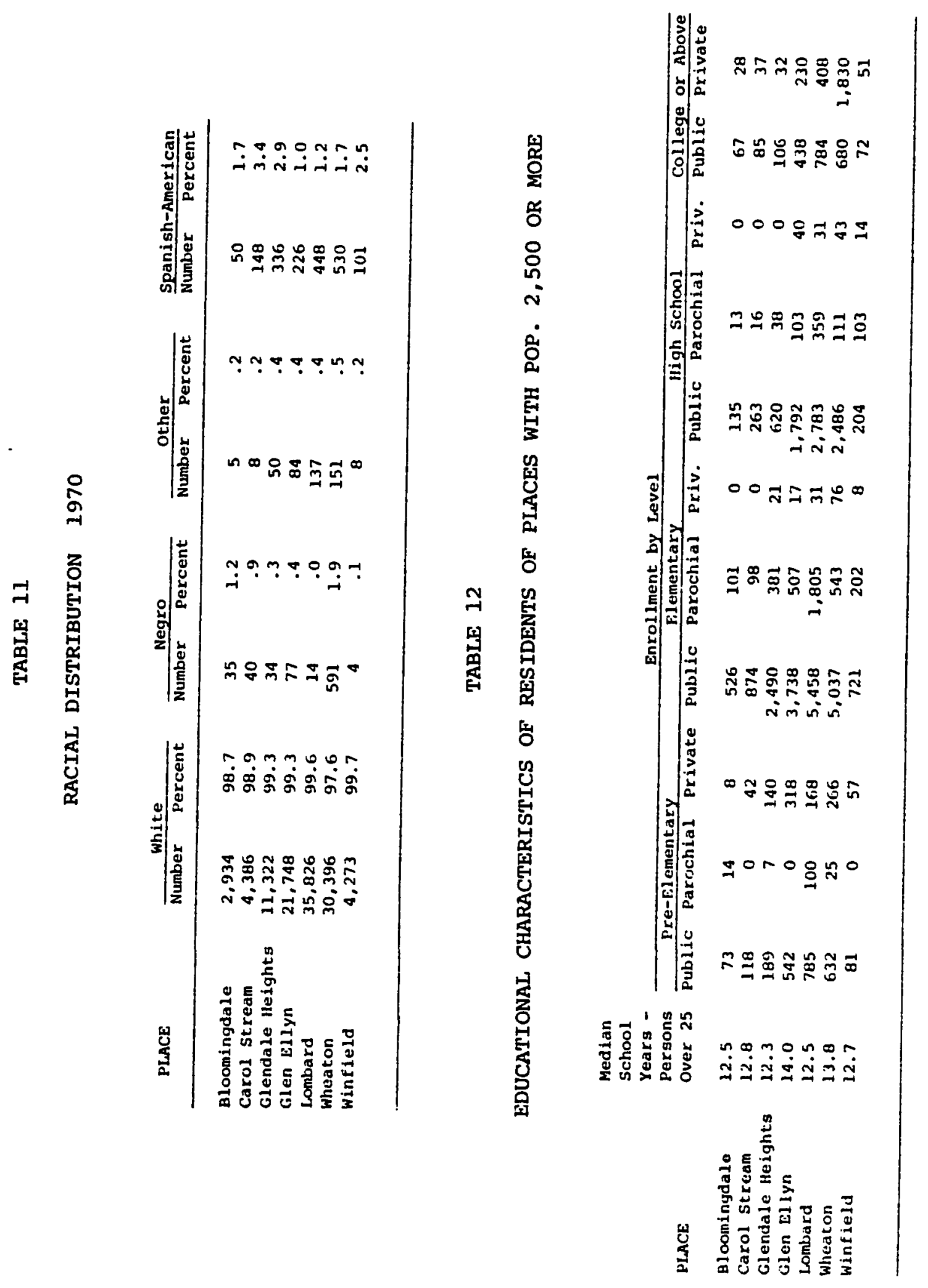


\section{$\begin{array}{llllllllll}A & P & P & E & N & D & I & X & & K\end{array}$}

Specific goals established

Reproduced with permission of the copyright owner. Further reproduction prohibited without permission. 
Exhibit $\mathrm{K}-\mathrm{I}$

SPECIFIC GOAIS . .

(1) KOINONIA

To hold a fellowship luncheon and seminar every second week

To hold a mid-week study group in members' homes

To draw up a membership directory

To appoint a church chaplain

To establish a prayer list

(2) PROCLAMATION

Each member to invite one friend to church once a month

To hold a vacation Bible School with follow up story Hour

To hold a Creation-Science Seminar

To advertize our denominational media programs through newspaper ads, radio spots and ten calls per week per members over

the phone or door to door

To hold an outreach program in the Fall in conjunction with the Lake Union Soul winning Institute-comprising:

Lay Training classes together with visitation of interests Community Service Health programs

Daniel seminars

Revelation Lectures

(3) SERVICE

To hold one nutrition class per quarter

To hold one smoking clinic per quarter

To hold one drug abuse seminar

To hold an organic gardening class

To complete the first floor of the church by June 81 
$\begin{array}{lllllllllllllll}A & P & P & E & N & D & I & X & & \text { L }\end{array}$

Marriage Vows

Reproduced with permission of the copyright owner. Further reproduction prohibited without permission. 
Exhibit L-1

\section{MARRIAGE VOWS OF SCOTT AND GAYLE WILLIAMS}

Scott to Gayle

GAYLE: Always remember that the Lord is your Maker and your Husband.

You are His bride of which our marriage is a type of the marriage that will take place when Christ returns for His church.

The vows of the covenant I am giving to you are a type of the vows Jesus took in our place to reconcile us to His Father.

By faith in Him, we are declared to be perfect covenant keepers.

The covenant we now make is based on the fact that God has accepted and forgiven us and therefore I will accept and forgive you.

Gayle, the Lord our God has led us together.

I promise not to put my supreme affections before anyone but the Lord our God.

I promise not to put any idolatrous interests before the Lord our God. I promise not to take the name of the Lord our God in vain.

I promise to rest on the seventh-day Sabbath with you as the Iord our God has commanded.

I promise to honor both our parents with you.

I promise not to hurt you in any way.

I promise not to commit adultery.

I promise not to steal your affections.

I promise not to lie to you.

I promise to be happy with you, whom God has given me.

\section{Gayle to scott}

SCOTT: I recognize that we all stumble in many ways and only Jesus is the perfect covenant keeper.

But I accept your pledge and give you the following pledge:

Gayle then repeated the same vows. 


\section{$\begin{array}{llllllllllllllll}\text { A } & P & P & E & N & D & I & X & & M\end{array}$ Letter from conference president}




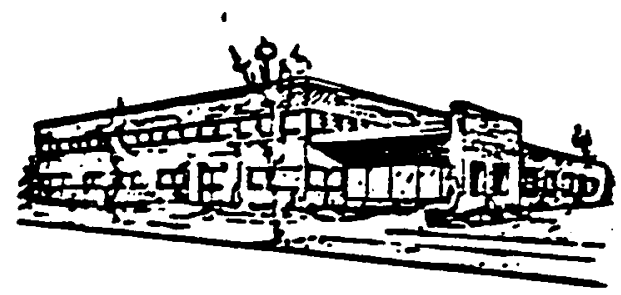

\section{ILLINOIS CONFERENCE} OF SEVENTH.DAY ADVENTISI,

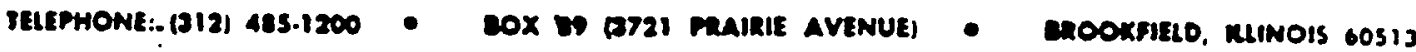

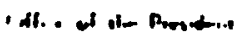

Decenber 17. 1979

Eder Gracen Lofen

21der Iruce Jox

Ider Mehurd alset

Dear Brethres:

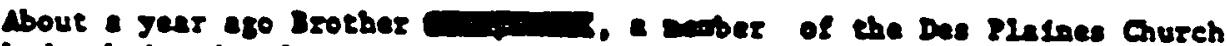
hed aubitted - document on propbet1c laterpreterlod of ebe book of Danied relative to the judgent hleh he belleved the lord had revealed to hl.

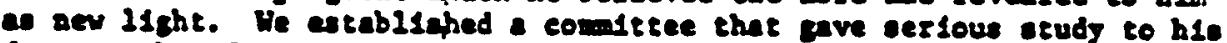
docuent but found it to be uneriptural and coatradietors to the bistoric poste1on of the S.D.A. Chureh.

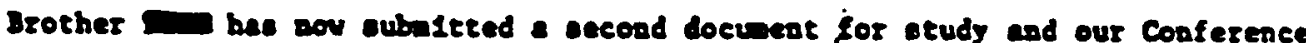
Executive Combttee is ablog if you three bretbren vould gerve on this

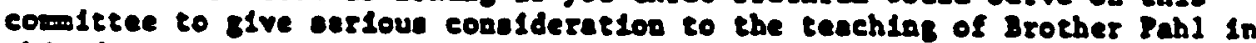
th1. docupent. We are ookiog Irother Ioftua to eerve we ehelrmen of that comitree ad vill look to bil to call jour flrat wetlog.

Irother In puteing the flalohtas touchee op ble document and ab coon ar he has subeleted It to Craese ve vould be bappy to duplicate it here at the offlce to provide coples for Bruce and Ilehard so that you brethcen any elve satilal otudy to it before your flret seetiag.

You ay also ulab to Iarite somone Eron Andrew Dalveralty to olt vith you 16 poselble as did our laet conattee which was chalred by John Balduin.

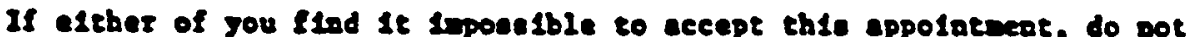
bestete to let we bow. Othervise ve vill presume thet you are accepting and you any look formand to hearlag fren Grecen geletive to the eppolntsent cebedule.

Thank you, Iretbrea, for coaniderat10a of thle rather ungque ad opecled request.

Very cordinlly yours,

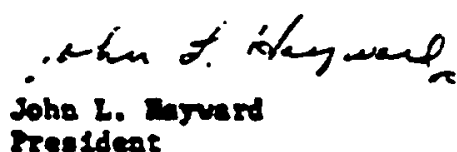

Ju/ve 
$\begin{array}{llllllll}A & P & P & E & N & D & I & X\end{array}$

Letter to parishioner

Reproduced with permission of the copyright owner. Further reproduction prohibited without permission. 
1014-2 Arthux Avenue Drookf1eld, IL 60513

Apri1 3. 1980

Dear

The comitte he subnitted 1ts report to Elder faymood and he will pass it on to you, but I feel it would be helpful if I shared a few personal reactions with you.

There is a basic hermeneutical approach to scripture which you are desing in all your presentations, and this can only be gained by atudy on your part. I would even suggest you do a course or two at Andrewa seminary in this area, parhaps over the sumer.

At a deeper level I see other dinensions in your need to repentedly present such a work. I had hoped that the experience of November 6 lest year would have sald sowething to you about the real essence of the type of date seteling ehing you are into. but it hasn't eaid enything. You reveal in this type of behavior a desperate guest for Identity. It seems that you have chosen the identity of a prophet, but I's sure frow several grounds that you have nistaken your identity.

(1) From a biblical point of view the mark of a false prophet 1s that his predictions don't cone true

(2) From a ccumunity point of view there is not one of your closest Eriends or church members at Glen Ellyn who would recognise that gift in you

(3) Your behmior patterns reveal one who is out of touch with reality. To be sure there is a time when the prophetic volce (not used in the predictive sense) must be heard, but sot on occasions when you have used it - when souls in thit church who have been so bruised by the tragedies of ilfe cose to the community for courage and support and atrength to tace another veek, only to feel the lash of your condemation. I am tempted to say it is a display of extreme self-righteousness, but I prefer to say it is poor judgment on your part and mistaken identity.

You do have weh to offer the church and I hope you won't retreat into complete isolation. Dut I would encourage you to resolve your ldentity problem as soon as possible, even with professional help, or else ultimately you will end up either a dissllusioned, frustrated and discouraged person or else a mentally unstable persos. went that way for exactly the same identity reasons as you experience and I can soe all of the same signs in your 11 fe that vere evident in his. You have too meh of positive good to ahare with the church and the world to let thnt mppen. Hy earnest plea as yous pastor is that you don't pass off these deep concerns of aine as aistaken judgment. Share this letter whth any of your friends and see whether they don't give you the same foedbuck. We aeed to lieten to godly feedback. It bas a biblicel base of the body of chriet in koinonia frow which you are vithholding yourself in lsolation and seem to be Igroring.

Yours aincerely.

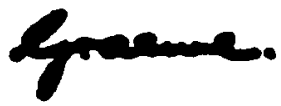


SELECTED BIBLIOGRAPHY

Books

Aquinas, Thomas. Summa Theologica. 3 vols. New York: Benziger Brothers Inc., 1947.

Barth, Karl. Church Dogmatics. 4 vols. New York: Charles Scribner's Sons, 1956.

- On Marriage. Philadelphia: Fortress Press, 1968.

Berkouwer, G. C. The Work of Christ. Grand Rapids: Eerdmans, 1965.

Bianchi, Eugene C. Reconciliation, The Function of the Church. New York: Sheed and Ward, 1969.

Boltensweiler, Heinrich. Die Ehe in Neuen Testament. Zurich/Stuttgart: Zwingli Verlag, 1967.

Bonhoeffer, Deitrich. Life Together. New York: Harper \& Row, 1954.

Brinsmead, R. D. This Is Life. Fallbrook, Ca.: Verdict Pub., 1978.

Bultmann, R. Theology of the New Testament. New York: Charles Scribner's Sons, 1951.

Butler, R. N. Why Survive? New York: Harper \& Row, 1975.

Campbell, R. How to Really Love Your Child. Wheaton: Victor Books, 1977.

Clinebell, H. J., and Clinebell, C. H. The Intimate Marriage. New York: Harper \& Row, 1954.

Come, A. B. Agents of Reconciliation. Philadelphia: Westminster Press, 1966 .

Conway, J. Men in Mid-Life Crisis. Elgin, Illinois: David C. Cook Pub. Co., 1978.

Denney, James. The Christian Doctrine of Reconciliation. New York: George H. Doran, 1918. 
Dodd, C. H. Christianity and the Reconciliation of the Nations. S.C.M. Press, 1952 .

Douglas, J. D., ed. Let the Earth Hear His Voice. Minneapolis: World wide Publications, 1975.

Dudley, R. C. Why Teenagers Reject Religion. Washington, D.C.: Review \& Herald, 1978.

Dunn, J. D. G. "Paul's Understanding of the Death of Jesus." In Reconciliation and Hope, P. 139. Edited by R. J. Banks. Exetor: Paternoster Press, 1974.

Duquoc, C. "Real Reconciliation and Sacramental Reconciliation." In Sacramental Reconciliation, p. 27. Edited by E. Schillebeeckx. New York: Harder and Harder, 1971.

Ellacuria, I. "Liberation: Mission and Charism." In Theological Foundations for Ministry, pp. 612, 616, 621. Edited by R. S. Anderson. Grand Rapids : Eerdmans, 1979.

Epistle of Ignatius to the Smyrnaens. The Ante-Nicene Fathers, 7. $1: 89$.

Fitzmyer, J. A. Pauline Theology. Englewood Cliffs: N.J.: Prentice Hall, 1966.

Forsyth, P. T. The Cruciality of the Cross. London: Hodder and stoughton, n.d.

Fowler, J., and Keen, S. Life Maps; A Journey of Faith. Waco, Texas: Word, Inc., 1978.

FrankI, V. E. Man's Search for Meaning. Boston: Beacon Press, 1962.

Fromm, E. Man for Himself. Greenwich: Fawcett, 1969.

Gerhardsson, B. "Sacrificial Service and Atonement in the Gospel of Matthew." In Reconciliation and Hope, pp. 25-35. Edited by R. J. Banks. Exetor: Paternoster Press, 1974.

Gray, R. M., and Moberg, D. O. The Church and the older Person. Grand Rapids: Eerdmans, 1977.

Griffen, K. "The Church as a Therapeutic Community." In Theological Foundations for Ministry, p. 735. Edited by R. S. Anderson. Grand Rapids: Eerdmans, 1979.

Groome, T. H. Christian Religious Education: Sharing Our Story and Vision. San Francisco: Harper \& Row, 1980.

Hamilton, K. "Reconciliation and the New Humanity." In Reconciliation in Today's World, p. 35. Edited by A. O. Miller. Grand Rapids: Eerdmans, 1969. 
Harkness, G. The Ministry of Reconciliation. Nashville/N.Y.: Abingdon, 1971 .

Hermas Pastor Similitude. The ite-Nicene Fathers, 5.6.2:35.

Hessel, D. T. Reconciliation and Conflict: Church Controversy over Social Involvement. Philadelphia: Westminster Press, 1969.

Horney, K. The Neurotic Personality of our Time. New York: $W$. W. Norton, 1964.

Hurlock, E. B. Developmental Psychology. New York: McGraw Hill, 1980.

Ignatius Epistle to the Smyrnaens. The Ante-Nicene Fathers, 7.1:89.

Justin Martyr Dialogue with Trypho. The Ante-Nicene Fathers, 13.

Kinlaw, D. C. Helping Skills for Developing Human Resources. Norfolk: Commonwealth Training Associates, 1978.

- "Sharing the Ministry of Interpersonal Help." Instruction material for Commonwealth Training Associates received when taking the class M-608 Pastor as Skilled Helper, in the Winter Quarter 1979-80 at the McCormick Theological Seminary.

Ladd, G. E. The Presence of the Future. Grand Rapids: Eerdmans, 1964.

Lasch, C. The Culture of Narcissism. New York: Warner, 1979.

Latourette, K. S. Christianity through the Ages. New York: Harper \& Row, 1965.

Leas, S., and Kittlaus, P. Church Fights. Philadelphia: Westminster Press, 1973.

Martin, R. P. "Reconciliation and Forgiveness in Colossians." In Reconciliation and Hope, pp. 104-124. Edited by R. J. Banks. Exetor: Paternoster Press, 1974.

McSorley, Harry. "Luther and Trent on the Faith Needed in the Sacrifice of Penance." In Sacramental Reconciliation, p. 98. Edited by $E$. Schillebeeckx. New York: Harder and Harder, 1971.

Miller, D. G. "God Reconciles and Makes Free." In Reconciliation in Today's World, P. 16. Edited by A. O. Miller. Grand Rapids: Eerdmans, 1969.

Miller, P. M. Peer Counselling in the Church. Scottcale: Herald, 1978. 
Milne, B. We Belong Together. Downers Grove: Intervarsity Press, 1978 .

Morris, Leon. The Apostolic Preaching of the Cross. Grand Rapids: Eerdmans, 1965.

Oden, T. C. The Structure of Awareness. Nashville: Abingdon, 1969. - Kerygma and Counselling. San Francisco: Harper \& Row, 1978 .

Painter, J. "Eschatological Faith in the Gospel of John." In Reconciliation and Hope, pp. 36-52. Edited by R. J. Banks. Exetor: Paternoster Press, 1974.

Rader, w. The Church and Racial Hostility. Tubingen: J.C.R. Mohr, 1975 .

Reid, G. The Gagging of God. London: Hodder and Stoughton, 1971.

Rinker, Rosalind. Prayer, Conversing with God. Grand Rapids: Zondervan, 1959.

Ritschl, A. "The Christian Doctrine of Justification and Reconciliation." Vol. III. English trans. H. R. Mackintosh and A. B. Macaulay, eds. Clifton: Reference Book Publishers, 1966. In H. H. Ditmanson, Grace in Experience and Theology. Minneapolis: Augsburg Press, 1977.

Schaeffer, F. A. Pollution and the Death of Man. Wheaton: Tyndale, 1970.

Escape from Reason. Downers Grove: Intervarsity Press, 1972 .

Sheehy, G. Passages. New York: E. P. Dutton \& Co. Inc., 1976.

Snyder, H. A. The Problem of Wineskins. Downers Grove: Intervarsity Press, 1975.

Stewart, C. W. The Minister as a Marriage Counsellor. Nashville: Abingdon, 1970.

Strommen, M. P. Five Cries of Youth. New York: Harper \& Row, 1970.

Taylor, Vincent. Forgiveness and Reconciliation. London: Macmillan 1948.

Tertullian Baptism. The Ante-Nicene Fathers, 3:669.

Tillich, Paul. A History of Christian Thought. Edited by Carl E. Braaten. New York: Simon and Scinuster, 1967. 
Torrance, T. F. "The Church in the New Era of Change." In Theological Foundations for Ministry, p. 767. Edited by R. S. Anderson. Grand Rapids: Eerdmans, 1979.

Tournier, Paul. Guilt and Grace. Translated by A. W. Heathcote. New York: Harper \& Row, 1962.

Wagner, M. E. The Sensation of Being Somebody. Grand Rapids: Zondervan, 1975.

Winter, G. Love and Conflict. Garden City, N.Y.: Doubleday \& Co., 1958 .

Comentaries

Barrett, C. K. A Commentary on the Epistle to the Romans. New York: Harper and Brothers, 1957.

- A Commentary on the Second Epistle to the Corinthians. New York: Harper \& Row, 1973.

Bruce, F. F. The Epistle to the Ephesians. London: Pickering \& Inglis, 1961.

Buttrick, G. A., ed. Interpreter's Dictionary of the Bible. 4 vols. New York: Abingdon Press, 1962.

Calvin, John. Commentaries on the Epistle of Paul the Apostle to the Romans. Grand Rapids: Eerdmans, 1947.

- Commentary on the Epistle of Paul the Apostle to the Corinthians. 2 vols. Grand Rapids: Eerdmans, 1948.

- Institutes of the Christian Religion. 2 vols. Edited by

J. T. McNeill. Philadelphia: Westminster Press, 1977.

Carson, H. M. The Epistles of Paul to the Colossians and to Philemon. Grand Rapids: Eerdmans, 1960.

Faulkes, B. The Epistle of Paul to the Ephesians. Grand Rapids: Eerounans, 1963.

Hodge, C. Second Epistle to the Corinthians. London: Banner of Truth Trust, 1959.

Hughes, P. E. Paul's Second Epistle to the Corinthians. Grand Rapids: Eerdmans, 1962.

Kittel, G., ed. Theological Dictionary of the New Testament. Grand Rapids: Eerdmans, 1964-1976. 
Lampe, G. W. H. A Patristic Greek Lexicon. Oxford: Clarendon Press, 1961.

Lloyd-Jones, D. M. Romans. London: Banner of Truth Trust, 1971.

Moule, H. C. G. Epistle of Paul the Apostle to the Colossians and to Philemon. Cambridge: University Press, 1906.

Murray, J. The Epistle to the Romans. 2 vols. Grand Rapids: Eerdmans, 1952 .

"Reconciliation with God." New Catholic Encyclopedia. New York: McGraw Hill, 1967. 12:129.

Schelkle, K. "The Second Epistle to the Corinthians." In The New Testament For Spiritual Reading. Edited by J. C. McKenzie. New York: Herder \& Herder, 1969.

Strachan, R. H. The Second Epistle of Paul to the Corinthians. Iondon: Hodder and Stoughton, 1954.

Thrall, M. E. The First \& Second Letters of Paul to the Corinthians. Cambridge: The University Press, 1965.

Vorlander, H. "Reconciliation." The New International Dictionary of the New Testament Theology. Grand Rapids: Zondervan: 1978.

Zerwich, M. The Epistle to the Ephesians. New York: Herder \& Herder, 1969.

Periodicals

Aldrich, W. M. "The Objective Nature of Reconciliation." Bibliotheca Sacra 118 (January 1961):18.

Ford, D. "The Valley of Desperation." Australasian Record, August 1977, p. 10.

Furnish, V. P. "The Ministry of Reconciliation." Currents in Theology and Mission 4 (August 1977):216.

Henry, C. F. H. "Evangelicals: Out of the Closet but Going Nowhere." Christianity Today, January 4, 1980, Pp. 18-20.

Kimbrough, S. T., Jr. "Reconciliation in the old Testament." Religion in Life 41 (Spring 1972):37-45.

Klooster, "Karl Barth's Doctrine of Reconciliation." Westminster Theological Journal 20 (May 1978): 182 . 
Loftus, G. S. "One Man's Odyssey." Australasian Record, October 15, 1979, pp. 1, 2.

Mason, N. "The High Risks of Preaching the Gospel." Australasian Record, November 17, 1975, p. 2.

Miller, D. G. "Toward a Theology of Evangelism." Christianity Today, May 8,1980, p. 6.

"Ministerial Association Advisory Report," Ministry, October 1979, p. 20.

Moltmann, J. "God Reconciles and Makes Free." The Reformed and Presbyterian world 31 (Dec 1970):112.

Morris, Leon. "Reconciliation." Christianity Today, 1969, p. 331.

Morrison, C. "God's Reconciling Work." McCormick Quarterly 19 (January 1966):87.

Murray, J. "The Reconciliation." Westminster Theological Journal 29 (November 1966): 3 .

Rowlingson, D. T. "The Minister's Role as Reconciler." Religion in Iife 35 (1955):57-66.

Ulanov, A. B. "The Two Strangers." Union Seminary Quarterly Review 28 (Summer 1973):273, 4.

Walvoord, J. F. "Reconciliation." Bibliotheca Sacra 120 (January 1963) : 4 .

Wilczak, P. F. "The Pastoral Care of Families: A Ministry of Reconciliation." Encounter 39 (Spring 78):180.

Wilder, A. N. "Reconciliation-New Testament Scholarship and Confessional Differences." Interpretation 19 (1965):317. 
VITA SHEET

Graeme Stanley Loftus was born on August 19, 1938, at Bunbury, Western Australia. His parents were not Seventh-day Adventists, and he completed all of his elementary and secondary education in public schools. He was baptized at Geraldton, Western Australia, on December 17, 1956 by Pastor F. T. Maberly. He completed a Bachelor of Engineering Degree at the University of Western Australia on May 10, 1961 and worked as a Civil Engineer for the Western Australian Government Rajlways for three years. Leaving that profession he entered Avondale College and graduated on November 20, 1966 with a Bachelor of Arts Degree in Theology, issued from Pacific Union College. He entered the ministry in 1967 serving the Western Australian Conference for seven years in the role of pastoral evangelism. During this time he met Avalon Muriel Grant and they were married on December 1, 1968. From this union have come two sons; Jereny Grant, born November 30, 1971 and Benjamin Reid, born July 16, 1974. He was ordained to the ministry in January 1974. Following one more year of pastoral evangelism in 1975 in the North New South Wales Conference he took up an appointment as chaplain of the Auckland Adventist Hospital in Auckland, New zealand under the auspices of the Trans Australian Union Conference. Here he served for two years as chaplain, evangelist, and pastor of the associated church. 
In December 1977 he left New Zealand under partial sponsorship from the Australasian Division to complete the Master of Divinity Degree from Andrews University. This was granted on August 5, 1979 and work was begun immediately on the Doctor of Ministry. In order to conduct this project according to the requirements of the degree, he worked as a pastor with the Illinois Conference for two years until June 1981.

He has written several articles published in denominational journals. 